\title{
Gut feelings in general practice
}

Citation for published version (APA):

Stolper, E. (2010). Gut feelings in general practice. [Doctoral Thesis, Maastricht University]. Datawyse / Universitaire Pers Maastricht. https://doi.org/10.26481/dis.20100226es

Document status and date:

Published: 01/01/2010

DOI:

10.26481/dis.20100226es

Document Version:

Publisher's PDF, also known as Version of record

\section{Please check the document version of this publication:}

- A submitted manuscript is the version of the article upon submission and before peer-review. There can be important differences between the submitted version and the official published version of record.

People interested in the research are advised to contact the author for the final version of the publication, or visit the DOI to the publisher's website.

- The final author version and the galley proof are versions of the publication after peer review.

- The final published version features the final layout of the paper including the volume, issue and page numbers.

Link to publication

\footnotetext{
General rights rights.

- You may freely distribute the URL identifying the publication in the public portal. please follow below link for the End User Agreement:

www.umlib.nl/taverne-license

Take down policy

If you believe that this document breaches copyright please contact us at:

repository@maastrichtuniversity.nl

providing details and we will investigate your claim.
}

Copyright and moral rights for the publications made accessible in the public portal are retained by the authors and/or other copyright owners and it is a condition of accessing publications that users recognise and abide by the legal requirements associated with these

- Users may download and print one copy of any publication from the public portal for the purpose of private study or research.

- You may not further distribute the material or use it for any profit-making activity or commercial gain

If the publication is distributed under the terms of Article $25 \mathrm{fa}$ of the Dutch Copyright Act, indicated by the "Taverne" license above, 
Gut Feelings in

\section{General Practice}


The studies presented in this dissertation were conducted under the auspices of the School for Public Health and Primary Care (CAPHRI) at Maastricht University, The Netherlands. CAPHRI is part of the Netherlands School of Primary Care Research (CaRe), which has been acknowledged since 1995 by the Royal Netherlands Academy of Art and Sciences (KNAW).

(C) 2010 Erik Stolper, Maastricht

Coverdesign: Dineke Stolper-van den Engel

Layout: Tiny Wouters

Production: Datawyse | Universitaire Pers Maastricht

ISBN: 9789052789088

Gut feelings in general practice are known in Dutch as 'pluis/niet-pluis', and pluis is also the Dutch word for the tufts on a dandelion flower; hence the picture on the front cover. 


\section{Gut Feelings in}

\section{General Practice}

PROEFSCHRIFT

ter verkrijging van de graad van doctor aan de Universiteit Maastricht, op gezag van de Rector Magnificus, Prof. mr. G.P.M.F. Mols,

volgens het besluit van het College van Decanen in het openbaar te verdedigen op vrijdag 26 februari 2010 om 16.00 uur

door

Erik Stolper

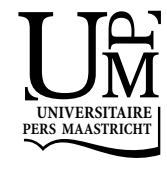




\section{Promotores}

Prof. dr. G.J. Dinant

Prof. dr. P. Van Royen (Universiteit van Antwerpen)

\section{Copromotor}

Dr. T. van der Weijden

\section{Beoordelingscommissie}

Prof.dr. P.W. de Leeuw, voorzitter

Prof. dr. F. Buntinx

Prof. dr. G. Glas (Universiteit Leiden)

Dr. A.F. Schilte

Prof. dr. P.M. van der Vleuten

These studies were partly supported by the Dutch organisation for Health Research and Development (ZonMw). 


\section{Contents}

Voorwoord

Chapter 1 Introduction

Chapter 2 The nature of diagnostic reasoning by experienced general practitioners

Huisarts en Wetenschap 2005;48:16-9

Chapter 3 "Gut feelings" in general practice in Europe.

A short report about recognition and expressions

Eur J Gen Practice 2010, provisionally accepted

Chapter 4 The diagnostic role of gut feelings in general practice.

A focus group study of the concept and its determinants BMC Family Practice 2009;10:17

Chapter 5 Consensus on gut feelings in general practice

BMC Family Practice 2009;10:66

Chapter 6 How do disciplinary tribunals evaluate gut feelings of doctors?

An analysis of Dutch tribunal decisions 2000-2008

Submitted

Chapter 7 Gut feelings as a third track in general practitioners' diagnostic reasoning

Submitted

Chapter 8 Establishing an international research agenda on gut feelings in general practice using the nominal group technique

Eur J Gen Practice 2010, accepted

Chapter 9 Discussion

Summary

Samenvatting

Curriculum Vitae 


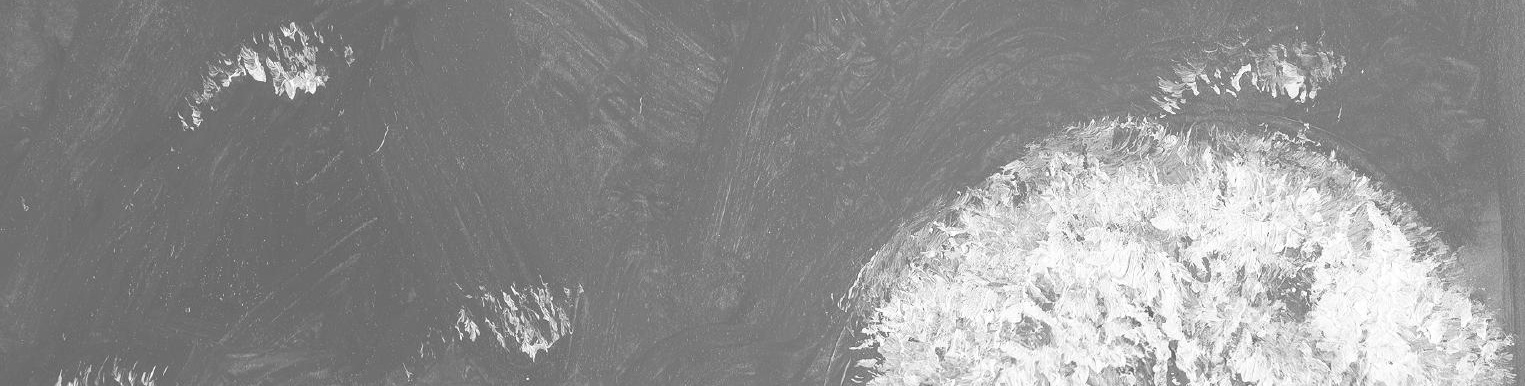

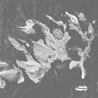
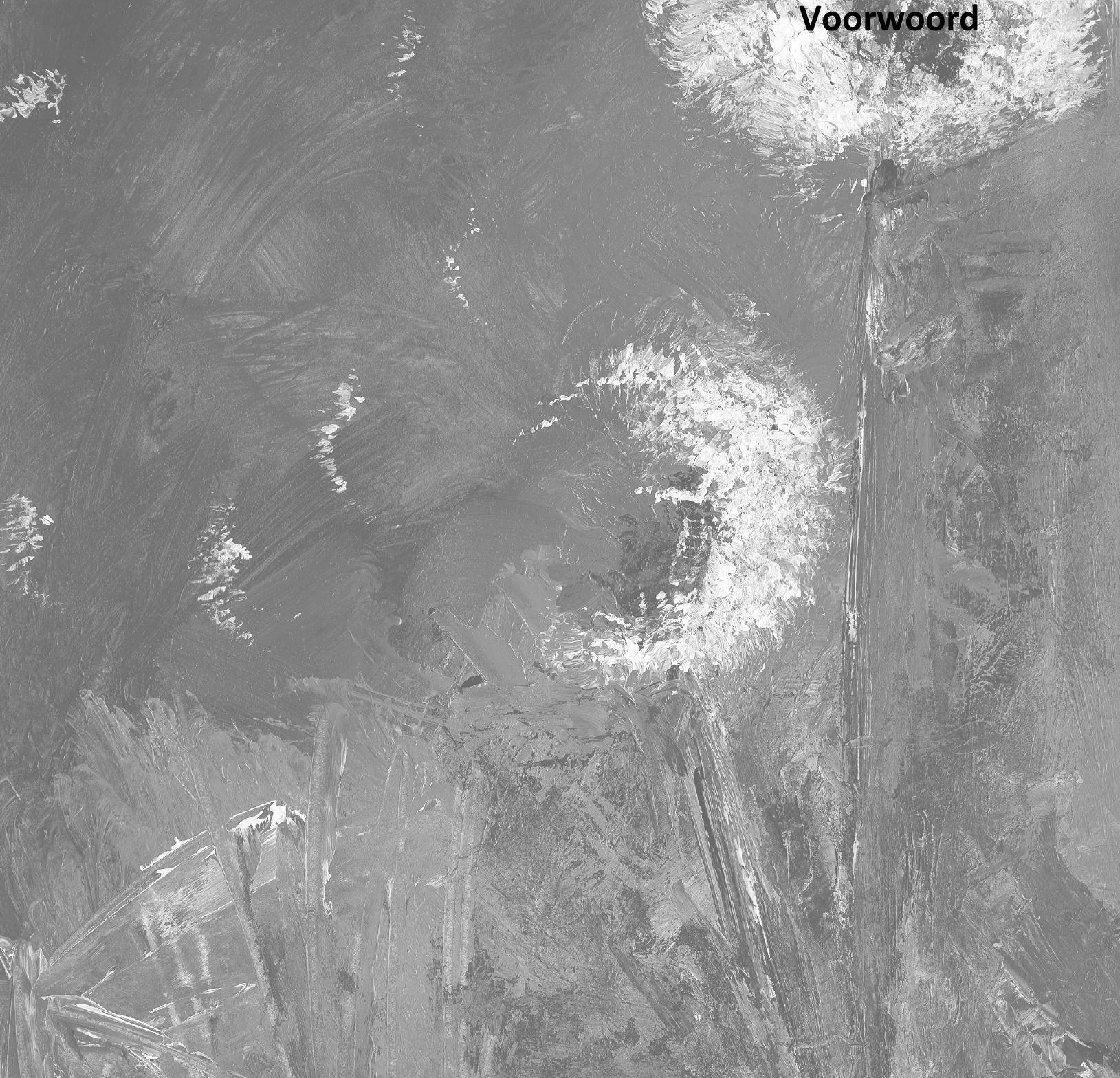


\section{Voorwoord}

Het is meer dan 30 jaar geleden. We staan samen achter het bureau in de grote spreekkamer van mijn opleider. Jaap Nauta is een ervaren huisarts, in zijn karakteristieke houding het hoofd iets naar voren gestoken, kauwend op het uiteinde van zijn pen, helemaal gespitst op diagnostiek. Ik ben huisarts in wording, onzeker, met mijn hoofd vol rijtjes symptomen en diagnoses. Natuurlijk staan we, want mijn opleider werkt snel. Een jonge patiënt stapt binnen, zijn rechterhand op de onderbuik, een beetje krom lopend. Hij ziet bleek om de mond maar er liggen blosjes op zijn wangen. Mijn opleider ziet het direct, in een flits herkent hij de diagnose. Pijn in de maagstreek begonnen, vertelt deze jongen, maar nu in onderbuik, geen koorts, overgeven en de kuilen in de weg verdraagt hij niet van de pijn. De patiënt klimt moeizaam de onderzoeksbank op, terwijl ik mijn rijtjes verzamel. Duidelijke druk- en loslaatpijn, McBurney positief. Appendicitis dus. Mijn opleider wist het al, nog voor de patiënt een woord gesproken had, eigenlijk nog voor hij goed had kunnen nadenken. Wat gebeurt hier eigenlijk? Zo heb ik dat niet geleerd toch?

Enkele jaren later, op Ameland, we rijden door de duinen, op de fiets, met de kids, kijker om de nek, vogelboek bij de hand. Een grote, bruine vogel zweeft een paar meter boven de grond, zwenkend en zwevend met steeds een paar slagen van die brede vleugels met rafelige uiteinden. Boek erbij en kijken en vergelijken: een bruine kiekendief. Aan het eind van die vakantieweek herkennen wij ze allemaal, in een oogopslag. De tijd gaat verder en vogelen wordt een hobby. Patroonherkenning heet dat proces, eigenlijk zonder bewust redeneren weten welke vogel daar vliegt. Hoe meer ervaring, hoe meer patronen in een flits worden herkend en de context is bij het vogelen belangrijk. In de geneeskunde heet deze diagnostiek flitsherkenning. Het blijft natuurlijk wel oppassen met al die flitsen en ook ervaren dokters vergissen zich soms. Het klopt eigenlijk niet wat ik denk, er is iets anders aan de hand, maar wat klopt er nou niet? Huisartsen gaan rechter op hun stoel zitten, alert en zoekend naar een verklaring voor dat ongemakkelijke en onrustig makende gevoel: er is hier iets niet pluis. Het kan ook gebeuren dat een huisartsopleider met een arts in opleiding een spoedvisite aflegt bij één van zijn patiënten met acute pijn op de borst. Snel lopen ze naar boven en kijken naar de man in bed. De ervaren opleider ziet het vrijwel onmiddellijk: dit is geen hartinfarct. Hij gaat rustig zitten. Terwijl de jonge dokter haar rijtjes afwerkt en een stethoscoop in haar oren stopt, denkt hij na: waarom heb ik direct al dat pluis gevoel? Zie ik geen dingen over het hoofd?

Hoe verloopt het diagnostisch denken van een ervaren huisarts en wat is dat toch voor een vreemd gevoel, dat 'niet-pluis' gevoel en ook dat 'pluis' gevoel? Legio zijn de verhalen van huisartsen die op basis van een 'niet-pluis' gevoel een patiënt instuurden zonder dat ze verder iets konden vinden. En kijk, ik had weer helemaal gelijk, kun je dan horen, een tevreden huisarts en terecht want het was wèl een infarct. Dat 
specifieke onderdeel van het diagnostisch denken van huisartsen vormt het onderwerp van dit proefschrift. En dit boekje is een product van een groep enthousiaste onderzoekers in Maastricht en Antwerpen. Zonder de inzet van al die verschillende talenten was het nooit wat geworden. Natuurlijk, het is een eerste stap in het ontrafelen van dat stukje diagnostiek maar we hebben een volgende stap al gezet en hopen samen nog meer stukjes van deze boeiende puzzel te kunnen leggen.

Er zijn veel mensen die mij onderweg geholpen hebben, op de route van dit onderzoek. Het is alsof ik verwonderd en nieuwsgierig een groot en interessant huis binnen stap, steeds een andere kamer binnenlopend, de trap op en verder kijkend, telkens bij de hand genomen door ervaren onderzoekers of enthousiaste huisartsen die uitleggen hoe ik de volgende stappen kan zetten. Dirk Avonts, coördinator van de opleiding tot huisartsonderzoeker, brengt mij in contact met Geert-Jan Dinant en hij zorgt voor een stevige Maastrichtse onderzoeksgroep met Trudy van der Weijden, Loes van Bokhoven, Margje van de Wiel en Paul Houben. Ik zie me nog zitten bij Paul Van Royen in Antwerpen, expert in kwalitatief onderzoek, met de vraag of hij mee wil doen. En tot onze vreugde stemt hij toe. Later komt Sjoerd Hobma Paul Houben vervangen. Deze ervaren en enthousiaste onderzoekers betekenen veel voor dit onderzoek en nog steeds, nu het project wordt voortgezet. De projectgroepvergaderingen zijn bijzonder stimulerend. Het is aanvankelijk niet de bedoeling dat het onderzoekstraject op een promotie zal uitlopen. Die stap is dus toch gezet op uitnodiging van Geert Jan Dinant en Paul Van Royen, mijn promotoren, en Trudy van der Weijden, mijn copromotor. Het is een erg groot genoegen om bij jullie te kunnen promoveren, zeer bedankt. Jullie vertrouwen is goed voor mijn vertrouwen. Geert Jan, je bent altijd present en reageert snel op mijn vragen en je inhoudelijk en strategisch goed doordachte adviezen zijn zeer waardevol. Paul, je hebt van mij een kwalitatief onderzoeker gemaakt en je uitgebreide netwerk heeft ons in staat gesteld het onderwerp op de Europese kaart te zetten. Loes en Trudy, dank voor jullie enthousiast meedenken en adviseren, meecoderen en analyseren en meeleven ook. Margje, dank voor je hulp om het theoretisch spoor uit te laten monden in een fraai Third Track manuscript. Paul $(\mathrm{H})$ en Sjoerd, dank voor jullie bijdragen.

Spannend zijn de focusgroepen: zullen we genoeg deelnemers krijgen? De medewerking is echter enorm. De eerste focusgroep start in Vaassen. Goed dat we een onafhankelijke moderator hebben in de vorm van Davy Theunissen want ze vraagt alsmaar door waar ik allang gestopt zou zijn. Dochter Yde zit er bij en typt later nauwkeurig het hele gesprek uit. Een andere keer sta ik in een café naar buiten te kijken, een regenachtig en donker plein op. Er hangen wat mensen aan de bar. Boven is alles klaar gezet voor een volgende focusgroep, inclusief wel twee bandopnameapparaatjes. Zullen de huisartsen die toegezegd hebben, komen? Ze komen dus vrijwel allemaal. In Heerenveen vindt de laatste focusgroepbijeenkomst plaats, allemaal jonge vrouwelijke huisartsen. In het gesprek blijkt hoe stevig deze jonge dokters in hun vak zitten: natuurlijk evidence-based, maar zonder dat pluis en nietpluis gevoel kunnen we wel op houden, zeggen ze. Dank Susanne Hanssen voor de 
fikse bijdrage als onderzoeksassistente in de eerste jaren en Mascha Twellaar die later haar taken overnam. Dank aan de huisartsen die in de beginfase van dit project geduldig 'niet-pluis' registreerden tijdens hun spreekuren. Dank ook aan alle deelnemers aan de Delphi consensusprocedure en aan de Nominale Groep bijeenkomsten. Het waren spannende en inspirerende bijeenkomsten, onder leiding van Saskia Mol en Yvonne van Leeuwen. Dank aan Johan Legemaate voor zijn enthousiast meewerken aan een duik in de archieven van de Medische Tuchtcolleges. Dank aan dochter Margreet die vooral in de beginfase vele artikelen kopieerde, aan zonen Karel en Jos die respectievelijk de gutfeelingsingeneralpractice.eu website bouwde en op cruciale momenten de laptop aan de praat hield. Dank aan dochters Annemarie en Christa die als paranimfen de nodige voorbereidingen zullen gaan treffen. Op de CWO (commissie wetenschappelijk onderzoek van de NHG) heb ik diverse malen feedback gekregen op conceptartikelen, dank jullie wel.

Dank aan ZonMw in de vorm van het Fonds Alledaagse Ziekten: ik sprong een beetje vreemd mijn spreekkamer door toen het bericht van de subsidie binnen kwam. Dank aan Lex Rutten, coauteur van het eerste manuscript dat al in de steigers stond toen ik in Maastricht startte. We besloten geheel zelfstandig en na uren redetwisten op een Lemster aak - een uitstekende plek om meningsverschillen op te lossen - dat sensitiviteit en specificiteit onwerkbare diagnostische begrippen waren en dus overboord gekieperd mochten worden, hetgeen we plechtig deden en wel in de Nieuwe Merwede. En we adopteerden niet minder plechtig de likelihood ratio om daarna met Rob Barthels en Roland Lugten een fraai prospectief onderzoekstraject in de homeopathie in te gaan wat inmiddels tot diverse internationale publicaties heeft geleid in peer-reviewed tijdschriften. Met Gerrit Glas en Dick Willems discussieerde ik over de kennistheoretische aspecten van 'pluis en niet-pluis' en over diverse emotietheorieën. Een artikel maken voor dit proefschrift bleek een te omvangrijke klus maar we pakken de draad weer op, binnenkort. Jan Klerkx corrigeerde alle hoofdstukken van dit boekje en het leest mijns inziens als een trein. Jan erg bedankt voor je geduld, adviezen en nauwkeurigheid. Tiny Wouters, dank voor je deskundige hulp bij het lay-outen van dit boekje.

We staan nu aan het eind van dit traject. Al deze mensen hielpen mee om de vaart in het onderzoek en de koers recht te houden maar ook om de puntjes op de i te zetten en de komma's op hun plek. Ik schrijf dit in september 2009. Thuis hebben we door ziekte erg spannende maanden achter de rug maar nu zijn we in een luwte beland, for the time being. Ik dank al onze kinderen voor hun enthousiasme en trouw. Ik dank Dineke zeer voor haar betrokkenheid; ze duwde me steeds de goede kant op maar liet me ook op tijd weer stoppen. Ze zorgde voor een heel mooie omslag van dit boekje. Ik dank onze Heer en God voor al die prima mensen die dit stuk van ons leven met ons mee gelopen zijn. 


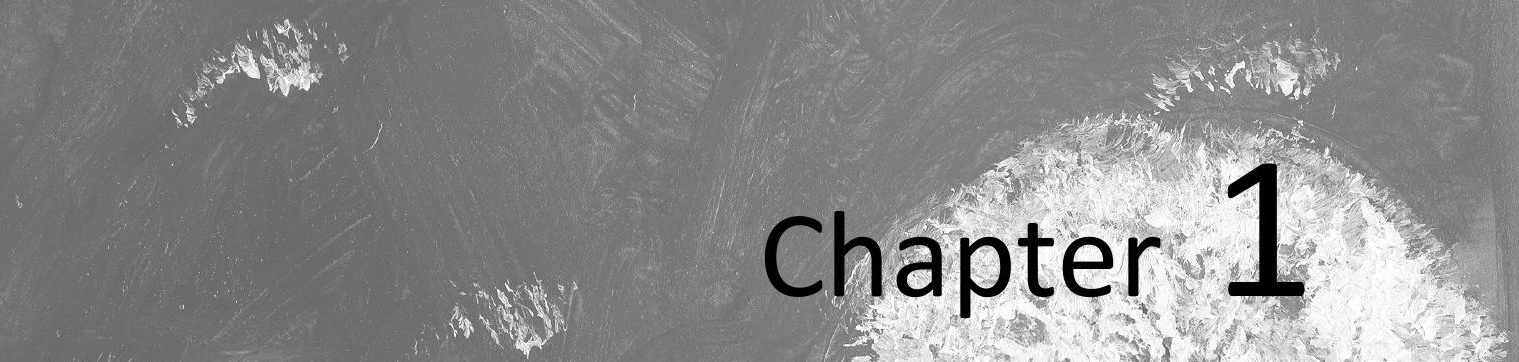

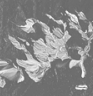

(1)
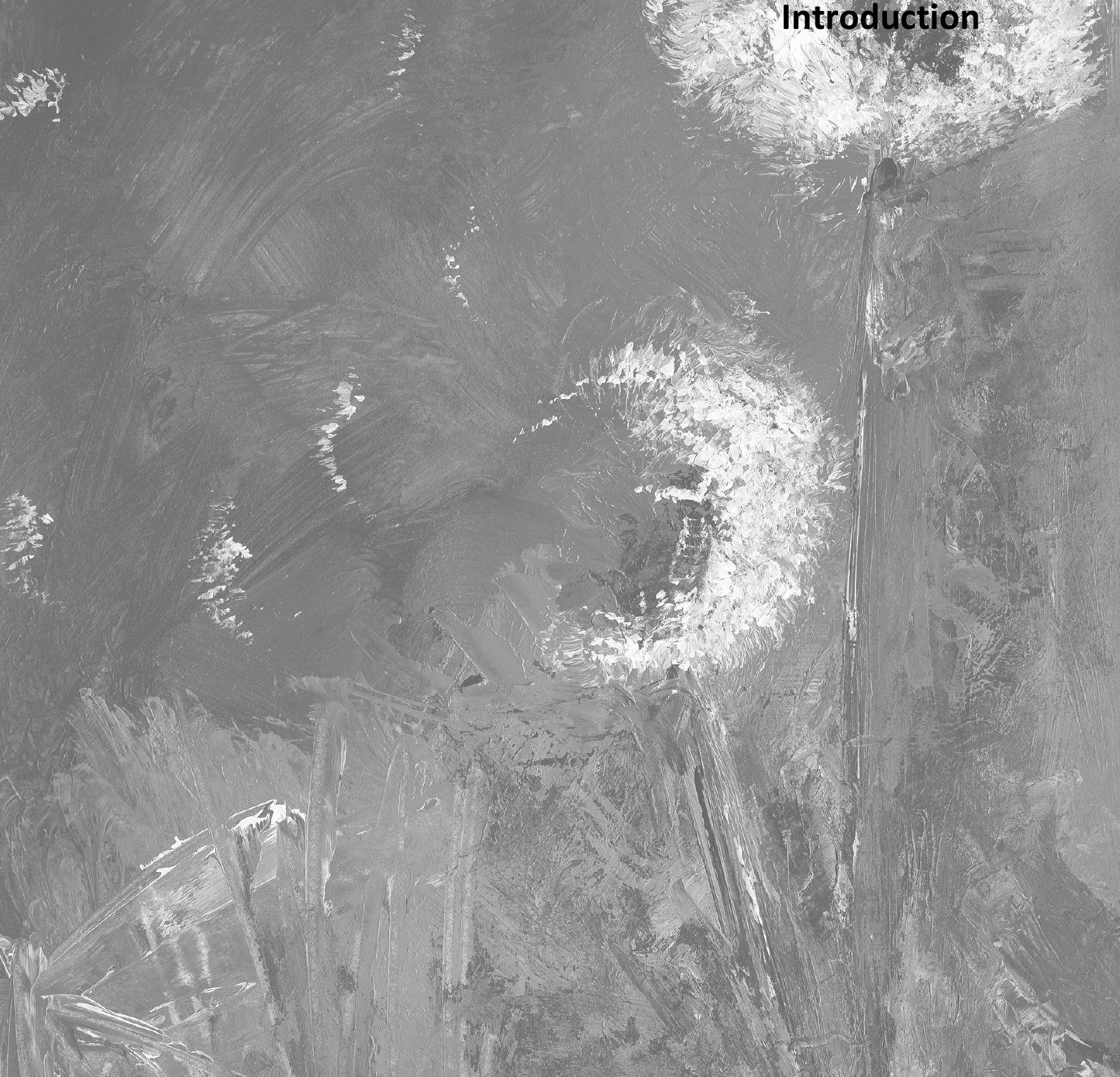
14 Chapter 1 


\section{Introduction}

\section{Between now and then}

Diagnostics lies at the heart of general practice medicine. In the Netherlands, thousands of people enter the consultation rooms of their general practitioner (GP) every day with a wide variety of complaints and concerns, with often minor but sometimes serious symptoms, with acute soreness or chronic pain, with grief, sadness or happiness. These problems are embedded in short and private tales or sometimes lifetime stories, and their presentation is influenced by different cultural contexts. ${ }^{1}$ In every encounter, GPs try to translate the patient's story into a possible diagnosis. They select symptoms and signs and integrate all the results of observation, historytaking and physical examination, ${ }^{2}$ routinely linking over 200 frequently occurring symptoms and complaints to one or more of the 400 diagnoses that are known to occur at least once per 1000 patients per year. ${ }^{3}$ Over $70 \%$ of all diagnoses in general practice are based on history-taking. ${ }^{4,5}$ Diagnostics is assumed to form the biggest part of a GP's work (80-85\%). ${ }^{6}$ A diagnosis may clarify the patient's story and enables the physician to propose appropriate therapeutic interventions, if necessary. ${ }^{7,8}$ However, GPs are sometimes unable to establish a clear diagnosis since a patient's complaints may be vague or the disease may be in its early stages. Dealing with uncertainty and unpredictability in complex situations is therefore a characteristic part of general practice. $^{9,10}$

General practitioners (GPs) in the Netherlands frequently use the rather typical Dutch expression "niet-pluis" (NP) to indicate the uneasy feeling that there may be something wrong with a patient, even though they have not yet establised a clear diagnosis. Conversely, the word "pluis" (P) seems to indicate the opposite situation, where a GP feels secure about how to deal with a patient's complaint, even without having a clear diagnosis. This "pluis" or "niet-pluis" (PNP) distinction is a well-known concept among Dutch and Flemish GPs and seems to serve as a surrogate variable for the prognosis, the expected course of a complaint or an illness. GPs normally predict a particular outcome in terms of the future of their patients' health, sometimes without being certain about the diagnosis, and the PNP concept seems to play a role in this assessment process. ${ }^{11}$ Koos van der Velden once said that a patient's confidence in their GP is largely based on whether these predictions turn out to be correct, that is, on their GP's predictive value. ${ }^{11}$

The expression "niet-pluis" has first been found in a document from 1632, ${ }^{12}$ while the earliest, and only, use of the adjective "pluis", in the sense of pure or smooth, is from 1588. Etymologically, the adjective "pluis" can be traced back to the Middle-Dutch verb "plusen" (modern Dutch "pluizen") and to "uteplusen", which originally meant plucking, stripping bare, later cleaning and nowadays picking apart or disentangling ("uitpluizen" in modern Dutch). Over the centuries, different meanings have been attached to the expression "het is niet pluis" such as that things are not OK, not as 
they should be or that someone is not in his right mind, is of unsound mind or there's danger here, something's amiss. Dutch Dictionaries only define the meaning of "pluis" in the negative form of "niet-pluis". ${ }^{13}$ A Dutch Medical Dictionary describes its medical meaning as follows: "term describing a physician's gut feeling about a complaint or a disease, when no diagnosis is available; intuition, experience and knowledge frequently allow a doctor to distinguish between innocuous, non-alarming complaints and serious disorders that necessitate further treatment". ${ }^{14}$ Perhaps the etymological explanation for this use of the expression "niet-pluis" relates to the urge for action, for a better look ("uteplusen"), for digging deeper into a patient's problem and trying to gain a better understanding of it, since there is something wrong, not secure, not smooth. In a lecture, the Dutch internist Sake Talma (1847-1918) told his audience about a GP - an excellent doctor in his opinion - who only had two diagnoses: "pluis" and "niet-pluis". He used to treat the former patients himself, while referring the latter to a hospital for further investigations and treatments. ${ }^{15}$

\section{What is known about the PNP concept in general practice?}

In the past, some researchers from the Maastricht University have tried to assess the diagnostic or prognostic value of the PNP concept. André Knottnerus found a positive correlation between a sense of NP perceived by GP trainees and the expected prior probability of carcinoma or endocrine diseases. ${ }^{16}$ Frank Buntinx evaluated GPs' first impression of chest pain in terms of $\mathrm{P}$ or NP, which he found to be rather accurate. ${ }^{17,18}$ Buntinx et al regarded PNP as a kind of diagnostic test which has to be taken seriously, especially by GPs. ${ }^{19}$ More recent research into the correct assessment of chest pain by GPs has confirmed this conclusion. ${ }^{20}$ Geert Jan Dinant followed 362 patients who were seen by their GP because of a new problem for which the GP wanted to know the erythrocyte sedimentation rate (ESR). ${ }^{21}$ The GPs recorded the most probable diagnosis, their clinical judgements in terms of "serious" and "not serious", and the expected ESR values, before and after the ESR determination. Dinant concluded that the GP's clinical judgement when he or she did not suspect serious pathology was rather reliable.

Tjeerd De Jongh et al. recently investigated the NP feeling among Dutch GPs with the help of a questionnaire and several vignettes. ${ }^{22}$ The authors concluded that the $P$ versus NP distinction is a common phenomenon in general practice and is related to situations of diagnostic uncertainty. This applies particularly to a sense of NP, since this stimulates a GP to initiate further diagnostics. During an encounter with a patient, a feeling of NP may arise from contextual information, signs and symptoms, or combination thereof. Experience and epidemiological knowledge are major determinants of having a feeling of NP. De Jongh et al. define NP as: "A situation is regarded as NP if there is a risk that the patient's disorder will cause him or her serious or irreparable harm if the doctor does not actively intervene. The main ingredients of the sense of NP are the seriousness of the possible diagnosis and the 
level of uncertainty with regard to this diagnosis. Handling the sense of NP correctly is an important skill for doctors, including GPs, offering them the opportunity to initiate suitable management without establishing a precise diagnosis". ${ }^{22}$ Since the predictive value of NP is still unknown, the authors recommended more research. These findings are in agreement with decisions of disciplinary tribunals, in which the value of NP has been evaluated. ${ }^{23-25}$ In one medical school programme, the NP feeling is regarded as a symptom that may indicate a serious disease and serves as a starting point in a diagnostic reasoning model. ${ }^{26-28}$ Students are taught to construct a "diagnostic landscape" by deducing hypotheses from signs and symptoms. The sense of NP is the pivot, or the central "hill" from which the student has to construct the other diagnostic hills in the landscape by first excluding serious diseases and then considering other diagnoses.

The significance of the PNP concept has been discussed in several medical journals. Some authors say that it is wrong to regard rationality and affect as opposites by denoting affect as non-scientific, since both cooperate in the diagnostic reasoning by experienced GP. ${ }^{29-31}$ Epistemological notions also play a part in the debate around PNP, since PNP should be regarded as a result of phronesis, the Aristotelian description of practical wisdom. ${ }^{32}$

\section{But do $\mathrm{P}$ and NP really exist in general practice?}

We tried to gain more insight into the relevance of the sense of NP for routine patient care in general practice by asking $14 \mathrm{GPs}$ and $10 \mathrm{GP}$ trainees to record the occurrence of NP feelings in each consecutive consultation during surgery or out of office hours within a certain period in 2004 during which they perceived a feeling of NP as well as their first diagnostic hypothesis. The participants were recruited with the help of the teaching staff of the Department of General Practice of Groningen University and of existing groups of GPs. NP was defined as "a possible serious health problem while the diagnosis is still uncertain". ${ }^{22}$ The participants received written information or a verbal explanation before the data were collected. Afterwards, a short questionnaire or an interview was used to question the participants about the feasibility of recording feelings of NP and about the time investment this required. Data collection was stopped after we had the impression that sufficient information had been gathered to evaluate the relevance of NP feelings in general practice. We assumed that the absence of NP could be interpreted as $P$.

PNP feelings were recorded during 2374 contacts (see Table 1.1 and 1.2). Physicians had an NP feeling in $7.5 \%$ of all contacts during surgery hours, a figure which was doubled during out of office hours (see Table 1.2). NP feelings seemed to be more frequently recorded by inexperienced GPs (a mean of 7.4\% for experienced GPs versus $11.4 \%$ for inexperienced GPs; $p=0.094$ ), and often related to the locomotor, vascular and gastrointestinal tracts (see Figure 1.1). Eighteen GPs provide information about the feasibility and time investment, and they all were positive about the practicability. 
The recording process took an average of 5-15 minutes a day. Recording during out of office hours was more difficult to achieve. It was not always easy to decide on the presence of an NP feeling, since the sense of NP can change during the encounter or disappear when a diagnosis is finally established.

Table 1.1 Experience.

\begin{tabular}{|c|c|}
\hline Number of GPs & $\mathrm{N}(\%)$ \\
\hline Total & 24 \\
\hline Male & $17(71)$ \\
\hline Female & $7(29)$ \\
\hline Experience as GP & years \\
\hline Total & $11.3 \pm 9.9 \mathrm{sd}$ \\
\hline 14 experienced (>8yr) & $18.2 \pm 6.9 \mathrm{sd}$ \\
\hline 10 inexperienced $(<4 \mathrm{yr})$ & $1.6 \pm 0.8 \mathrm{sd}$ \\
\hline
\end{tabular}

Table 1.2 Prevalence of PNP.

\begin{tabular}{lccc}
\hline experience 1-27 y & surgery hours (\%) & out of office hours (\%) & total (\%) \\
\hline NP & $162(\mathbf{7 . 5 \% )}$ & $33(\mathbf{1 4 . 9 \% )}$ & $195(\mathbf{8 . 2 \% )}$ \\
P & $1990(\mathbf{9 2 . 5 \% )}$ & $189(\mathbf{8 5 . 1 \% )}$ & $2179(\mathbf{9 1 . 8 \% )}$ \\
Total & 2152 & 222 & $2374(100 \%)$ \\
\hline
\end{tabular}

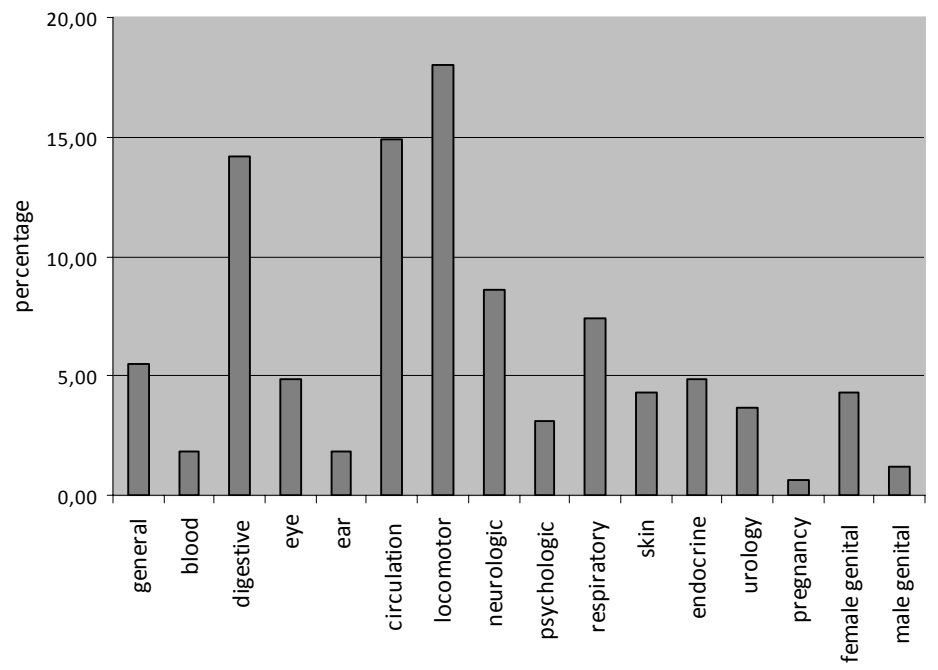

Figure 1.1 Percentage of NP related to ICPC code chapters.

We concluded that the PNP concept does play a role in GPs' diagnostic thinking, both among experienced and inexperienced GPs. Since this pilot study did not include a 
follow-up we were unable to ascertain the diagnostic accuracy of the PNP concept. Experienced physicians have greater knowledge about disease presentations and sometimes more information about the patient's personal story and context, which enables them to establish a diagnosis more quickly, more accurately and with more self-confidence, and they therefore probably perceive NP feelings less often. ${ }^{33}$

\section{Scope of the problem and research questions}

In summary, the PNP concept plays an undeniable role in the diagnostic reasoning of GPs. At the same time, it seems hard to get a grip on it. In fact, many scientists regard PNP as no more than an intuitive and vague feeling, and in the era of evidence-based medicine, intuitive and vague feelings as a part of the diagnostic process seem outdated. $^{34}$

Since our main goal was to gain insight into the nature and significance of PNP in general practice, we formulated the following questions for the research underlying this thesis:

- What is known from the literature about the nature of diagnostic reasoning by experienced GPs?

- What meaning and significance do GPs attach to feelings of P or NP and what opinions do they have about the PNP concept, as used in routine practice and during out of office hours? What determinants may play a role in developing the PNP feelings?

- How can we achieve consensus about a description of PNP which would enable us to operationalise this concept?

- Is PNP a typical phenomenon only among Dutch-speaking GPs or is it also recognised by GPs elsewhere in Europe?

- How do disciplinary tribunals in the Netherlands use PNP in their considerations and what does this mean for the professional standards on quality of health care?

- Are we able to explain how PNP arise and function within the physician's knowledge network?

- What research agenda can be drawn up for the validation of the concept of PNP and its value for routine practice and medical education?

We addressed these questions by first reviewing the literature on diagnostic reasoning. We then opted for a qualitative approach with focus groups, a Delphi consensus procedure and a nominal group technique, since our initial research questions asked for specific explorative methods. In addition, we searched relevant digital databases. 


\section{Outline of the thesis}

Chapter 2 describes the nature of diagnostic reasoning by experienced GPs. Experienced physicians often establish diagnoses quickly and efficiently, sometimes immediately identifying their patient's problem, although they were taught, at university to first list all signs and symptoms, and then to consider all possible diagnoses. We tried to find explanations for this discrepancy by identifying the most common theories of diagnostic reasoning, searching PubMed, general practice journals like the Dutch Huisarts \& Wetenschap and the Flemish Huisarts $\mathrm{Nu}$, as well as books and $\mathrm{PhD}$ theses relating to this subject. ${ }^{33,35-37}$

Most GPs in the Netherlands and in Flanders are familiar with the feelings of NP, which alerts a doctor, activates the diagnostic process and induces him or her to initiate specific management. However, we wanted to know if this kind of a gut feeling (see below) is a typical phenomenon of Dutch-speaking GPs or whether it would also be recognised by GPs elsewhere in Europe. In chapter 3 we present the results of a short questionnaire survey held among GPs in countries included in the European General Practice Research Network. Based on the results, we proposed to use the English phrase "gut feelings" in further research reports.

Research into the value of gut feelings requires an accessible and valid description of this phenomenon. In chapter 4, we report how we formulated the concept of gut feelings and how we identified the main determinants of this easily recognised but poorly described phenomenon. A focus group approach was chosen because this enabled us to concentrate on opinions, interpretations and significances that GPs attach to gut feelings. ${ }^{38-40}$ In focus groups, the members respond directly to each other, generating more questions about the topic at hand and sharing common experiences, while a moderator probes for further explanation.

Chapter 5 explores whether sufficient agreement can be reached on precise and valid descriptions of types of gut feeling by means of a Delphi consensus procedure among opinion leaders and experts in general practice in the Netherlands and Flanders. ${ }^{41,42}$ The descriptions they agreed upon were needed to operationalise the concept for further research and education.

Disciplinary tribunals in the Netherlands seem to use the gut feelings concept in their considerations when they pass judgement on physicians against whom a complaint has been filed. In the Netherlands, the judgments of these tribunals are considered to set standards for professional attitudes and interventions. In chapter 6 , we report on the way in which disciplinary tribunals evaluate the concept of gut feelings in their judgements and what this means for the professional quality standards in healthcare. ${ }^{43}$ We also present the results of attempts to search databases of medical tribunal decisions in Europe.

Although our research had considerably clarified the role of gut feelings in GPs' diagnostic reasoning, a scientific understanding was still lacking. To explain this role, chapter 7 presents a model of the diagnostic process obtained by reviewing the 
literature on diagnostic reasoning from various perspectives, as well as on the basis of psychological theories on dual processing. This model adds the role of gut feelings as a non-analytical mode of reasoning to the well-defined diagnostic tracks of medical problem-solving and medical decision-making. ${ }^{36,44-46}$

Although consensus on the two types of gut feelings, a sense of alarm and a sense of reassurance, had enabled us to operationalise the concept (see chapter 5), it was not yet clear what further research is needed to validate this concept of gut feelings and to estimate its value in routine practice and medical education. To find the answers, we used the nominal group technique to establish an international research agenda on gut feelings in general practice (chapter 8). ${ }^{47,48}$

In the final chapter, we summarize our main findings and discuss their significance and implications for medical education and further research, and we also discuss some epistemological aspects of gut feelings. 


\section{References}

1. Wolffers I. Cultural sensitivities [Culturele gevoeligheid]. MC 2004;59:196-9.

2. Aronowitz RA. When do symptoms become a disease? Ann Intern Med 2001;134:803-8.

3. Okkes IM, Oskam SK, Lamberts H. From complaint to diagnosis [Van klacht naar diagnose]. Bussum: Uitg.Coutinho; 1998.

4. Tielens VCL, Mokkink H, Mesker P. The GP's medical-diagnostic approach [Het medisch-diagnostisch handelen van de huisarts]. Huisarts Wet 1985;28:44-8.

5. Baerheim A. The diagnostic process in general practice: has it a two-phase structure? Fam Pract 2001; 18:243-5.

6. Everwijn SEM, De Melker RA. How do GPs and specialists work? [De werkwijze van huisarts en specialist]. Huisarts Wet 1985;28:302-6.

7. Bremer GJ. On diagnosis, GP's diagnostics and diagnostics in primary care. [Over diagnose, huisartsdiagnostiek en diagnostiek in het eerste echelon]. Huisarts Wet 1972;15(1).

8. Bremer GJ. Standards for illness......and patients [Standaarden bij ziekte ....en de zieke]. Huisarts Wet 1999;42:30-1.

9. Dinant GJ. Diagnosis and decision. Undifferentiated illness and uncertainty in diagnosis and management. In: Jones R, Britten N, Gulpepper L, Gass D, Grol R, Mant D, Silagy C, editors. Oxford Textbook of Primary Medical Care.Oxford: Oxford University Press. 2004:201-3.

10. Innes AD, Campion PD, Griffiths FE. Complex consultations and the 'edge of chaos'. Br J Gen Pract 2005;55:47-52.

11. Van der Velden HGM. Diagnosis or prognosis? The significance of epidemiology in GPs' procedures. [Diagnose of prognose? De betekenis van de epidemiologie voor het handelen van de huisarts]. Huisarts Wet 1983;26:125-8.

12. Debrabandere PMF, Quak A, Schoonheim T, Van der Sijs N. Etymological dictionary of Dutch. [Etymologisch Woordenboek van het Nederlands], 2003-2009. Amsterdam: 2009.

13. Den Boon T, Geeraerts D. Dictionary of the Dutch language [Groot Woordenboek van de Nederlandse Taal]. 14 ed. Utrecht/Antwerpen: Van Dale Lexicografie; 2005.

14. Van Everdingen JJE, Klazinga NS, Pols J. Medical Dictionary. [Geneeskundig Woordenboek]. 10 ed. Houten/Diegem: Ultgeverij Bohn Stafleu van Loghum; 1998.

15. Ten Doesschate G. Utrecht University and medical science 1836-1900 [De Utrechtse universiteit en de geneeskunde 1836-1900]. Nieuwkoop: De Graaf, 1963.

16. Knottnerus JA, Muller HK. Peer review: Practicing with trainee GPs. [Intercollegiale vergelijking: Oefenen met huisartsen in opleiding]. MC 1986;18(41).

17. Buntinx F, Truyen J, Embrechts P, Moreel G. Chest pain. From complaints to diagnosis [Pijn op de borst. Van klacht naar diagnose]. Huisarts Nu 1989;18:243-50.

18. Buntinx F, Truyen J, Embrechts P, Moreel G, Peeters R. Chest pain: an evaluation of the initial diagnosis made by 25 Flemish general practitioners. Fam Pract 1991;8:121-4.

19. Buntinx F. Supporting the GP's decision-making process. [Ondersteuning van het besliskundig denken van de huisarts]. 2000.

20. Buntinx F, Knockaert D, Bruyninckx R, de Blaey N, Aerts M, Knottnerus JA, Delooz H. Chest pain in general practice or in the hospital emergency department: is it the same? Fam Pract 2001;18:586-9.

21. Dinant GJ, Knottnerus JA, van Wersch JW. Diagnostic impact of the erythrocyte sedimentation rate in general practice: a before-after analysis. Fam Pract 1992;9:28-31.

22. De Jongh $\mathrm{TOH}$, Eekhof JAH, Van den Berg H. Acting in a situation of uncertainty. [Handelen in onzekerheid]. MC 2002;57:942-5.

23. Mollema K.E. Decision of the Dutch central disciplinary tribunal for healthcare, 16 december 2004. [Uitspraak Centraal Medisch Tuchtcollege voor de Gezondheidszorg dd 16 december 2004]. MC 2004;60:245-7.

24. Crul BVM, Rijksen WP. Ungrateful [Stank voor dank]. MC 2005;60:1796-9.

25. Crul BVM, Rijksen WP. The wrong track [Dood spoor]. MC 2005;60:2030-2.

26. Van Puymbroeck H, De Wachter J, Blanckaert F, Boeckx J, Bruyninckx R, Ferrant L, Debaene L, Van den Ende J. Clinical logic (part 1). From presenting complaint to diagnostic landscape. [Klinische Logica (deel 1). Van aanmeldingsklacht tot diagnostisch landschap]. Huisarts Nu 2004;33:123-8. 
27. Van den Ende J, Derese A, Vervaeck A, Van Gompel A. Complex analysis: the crowning achievement of diagnostics [Complexe analyse: de kroon op het diagnostische werk]. Huisarts Nu 1996;25:329-37.

28. Van Puymbroeck H, Remmen R, Denekens J, Scherpbier A, Bisoffi Z, Van den Ende J. Teaching problem solving and decision making in undergraduate medical education: an instructional strategy. Med Teach 2003;25:547-50.

29. Van Leeuwen YD. Gut feelings or protocol. [Pluisgevoel of protocol]. MC 2004;59:1464-5.

30. Van Leeuwen YD. GPs' experential knowledge. [De ervaringskennis van huisartsen]. Huisarts Wet 1998;41:80-4.

31. Ho VKY, Van der Steen WJ. Between medical science and medical practice: the practical value of evidence. [Tussen geneeskunde en geneeskunst; de waarde van evidence voor de praktijk]. Huisarts Wet 2005;48:337-49.

32. Goudsmit A. The role of "phronesis" in general practice medicine. [De plaats van de "phronese" in de huisartsgeneeskunde]. Huisarts Wet 2005;48:454-8.

33. Elstein AS, Shulman L, Sprafka S. Medical Problem Solving: an analysis of clinical reasoning. Cambridge, Mass.: Harvard University Press; 1978.

34. Van Megchelen P. Gut feelings or protocol. [Pluisgevoel of protocol]. MC 2004;30/31.

35. Dinant GJ, Van Leeuwen YD. Diagnosis and decision-making. Clinical diagnosis: hypothetico-deductive reasoning and other theoretical frameworks. In: Jones R, Britten N, Culpepper L, Gass D, Grol R, Mant D, Silagy C, editors. Oxford Textbook of Primary Medical Care.Oxford: Oxford University Press; 2004 : 203-5.

36. Elstein AS, Schwarz A. Clinical problem solving and diagnostic decision making: a selective review of the cognitive literature. BMJ 2002;324:729-32.

37. Haynes RB, Devereaux PJ, Guyatt GH. Clinical expertise in the era of evidence-based medicine and patient choice. ACP J Club 2002;136:A11-A14.

38. Pope C, Van Royen P, Baker R. Qualitative methods in research on healthcare quality. Qual Saf Health Care 2002;11:148-52.

39. Vermeire E, Van Royen P, Griffiths F, Coenen S, Peremans L, Hendrickx K. The critical appraisal of focus group research articles. Eur J of Gen Pract 2002;8:104-8.

40. Morgan DL. Focus groups. Annual Rev Sociology 1996;22:129-52.

41. Hasson F, Keeney S, McKenna H. Research guidelines for the Delphi survey technique. J Adv Nurs 2000;32:1008-15.

42. Jones J, Hunter D. Consensus methods for medical and health services research. BMJ 1995;311: 376-80.

43. Van Leusden MB, Jongerius $P$, Hubben JH. GPs and disciplinary procedures. [Huisarts en Tuchtrecht 1997 - 2007]. Den Haag: Sdu, Uitgevers BV; 2008.

44. Kahneman D. A perspective on judgment and choice: mapping bounded rationality. Am Psychol 2003; 58:697-720.

45. Epstein S. Integration of the cognitive and the psychodynamic unconscious. Am Psychol 1994; 49: 709-24.

46. Slovic P, Finucane ML, Peters E, MacGregor DG. Risk as analysis and risk as feelings: some thoughts about affect, reason, risk, and rationality. Risk Anal 2004;24:311-22.

47. Dunham R.B. Nominal Group Technique: a users' guide. Organisational Behavior 1998.

48. Carney O, McIntosh J, Worth A. The use of the Nominal Group Technique in research with community nurses. J Adv Nurs 1996;23:1024-9. 



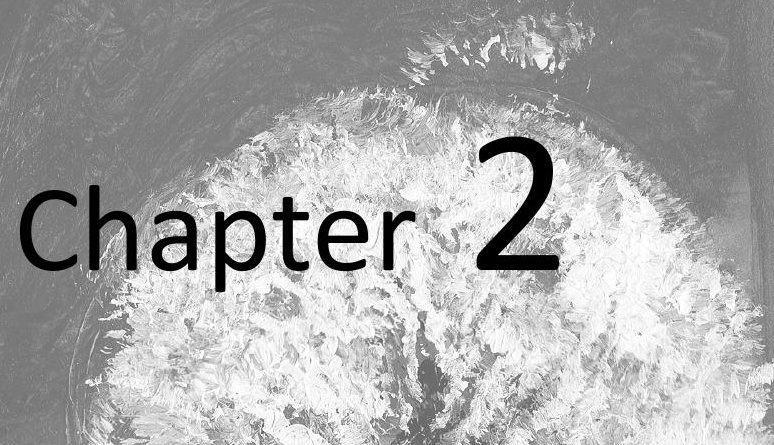

The nature of diagnostic reasoning by experienced
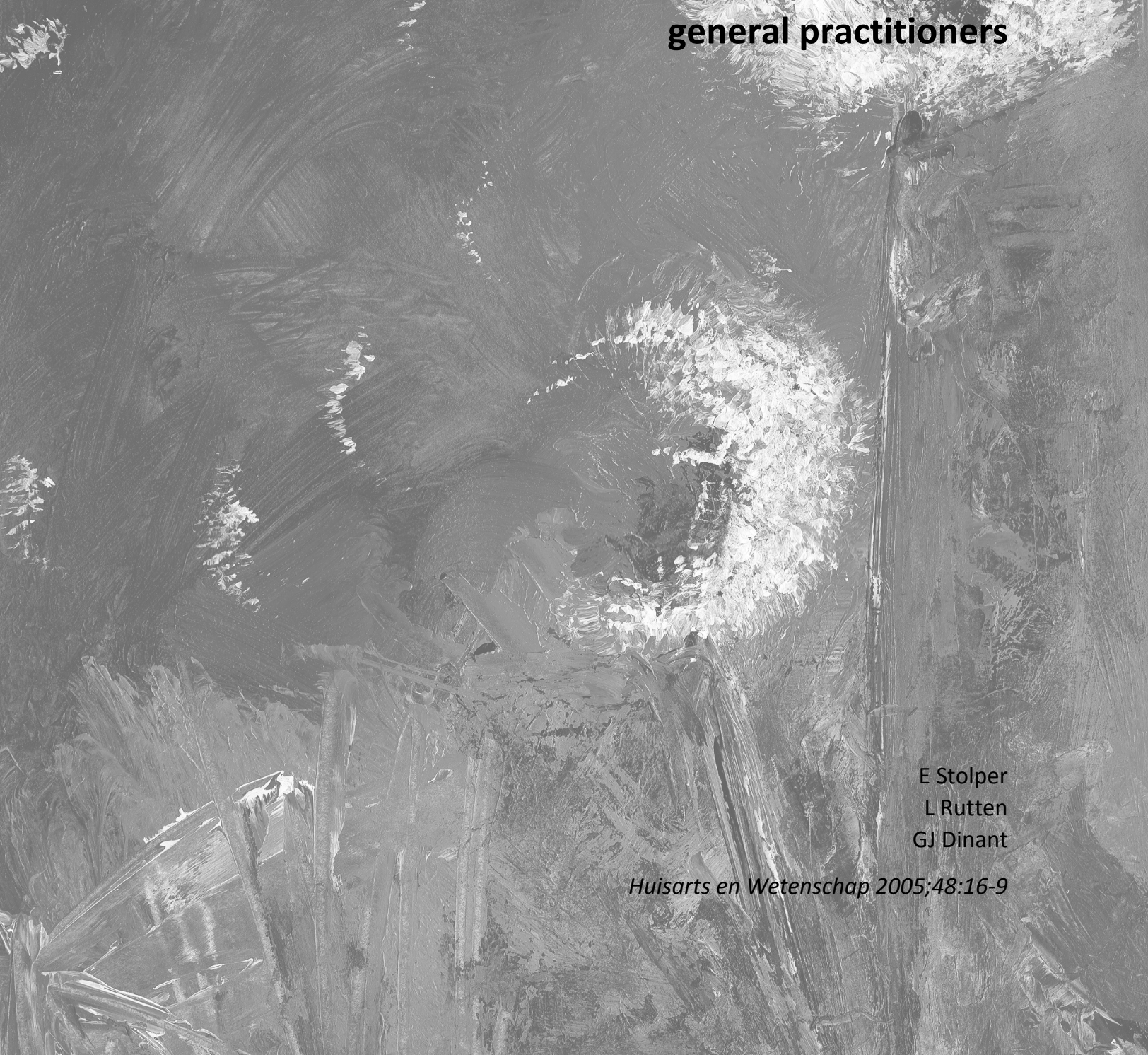


\section{Abstract}

\section{Background}

There is a discrepancy between the type of diagnostic reasoning that general practitioners (GPs) are taught to use and the way they actually solve diagnostic problems. What they are taught is that they should first systematically collect all relevant information about the patient, then undertake a pathophysiological analysis and finally establish a differential diagnosis. In practice, however, three quarters of all hypotheses that GPs and internists use to guide the questions they ask to confirm the hypotheses and to select the relevant information are generated in the first quarter of the consultation. The earlier a hypothesis is formulated in the consultation, the greater the likelihood that a correct diagnosis is established. Other tools recommended by medical decision-making theories are hardly used in routine practice. We tried to find explanations for this discrepancy by identifying the most common theories on diagnostic reasoning, especially for experienced GPs.

\section{Methods}

A search in PubMed, Huisarts en Wetenschap, Huisarts $\mathrm{Nu}$, and books and PhD theses relating to the subject.

\section{Results}

Two theoretical approaches were found: more qualitative research as used in psychology, with illness scripts and prototypes, and more quantitative research as used in medical decision-making theories, including Bayesian rule and the use of thresholds. The theory of illness scripts explains how as doctors gain experience: they transform the theoretical knowledge from medical school into more practical scripts involving three layers of knowledge, with shorter search paths. According to prototype theory, the encyclopaedic presentation of diseases in handbooks is replaced in a doctor's memory by prototypes of characteristic diseases within a category. Prototypes act as recognisable patterns, connected by numerous cross-links and enabling the experienced physician to establish diagnoses fast. Medical decision-making theories explain how the ability to work with thresholds is an important aspect of a GP's competence and experience-based knowledge. Doctors think in proportions and in categories of certainty rather than in numbers and odds, weighing up the available information in the context of the patient and predicting a particular outcome. Hypotheses become more likely or less likely, rather than being proved or disproved.

\section{Discussion}

The tension between evidence-based knowledge and experience-based knowledge may be explained by GPs' contextual knowledge which plays an important part in their diagnostic reasoning.

\section{Conclusion}

Experienced GPs think along several tracks simultaneously and the models described explain how knowledge gained during medical education is reorganised as a result of experience. 


\section{Introduction}

Diagnostics lies at the heart of general practice medicine, its main purpose being to allow the doctor to establish the patient's prognosis and decide on the right treatment. The main building blocks of the diagnostic process are history-taking and physical examination. ${ }^{1}$ In this process, a general practitioner (GP) links over 200 frequently occurring symptoms to one or more of the 400 diagnoses that are known to occur at least once a year. ${ }^{2}$ This means that evidence from research must be applied to the patient's specific situation. This is a complex process, as symptoms arguing for or against a certain diagnosis do not all carry the same weight, and the set of symptoms that a GP has in mind for a particular disease need not be the same for every physician. ${ }^{3}$ Research has shown that experienced GPs are better and faster at establishing the correct diagnosis than inexperienced ones. ${ }^{4,5}$ Such experienced physicians tend to recognise certain patterns immediately, and only in complex cases do they formulate multiple hypotheses. ${ }^{6}$

There is a discrepancy between the type of diagnostic reasoning that GPs are taught to use and the way they actually solve diagnostic problems in everyday practice. What they are taught is that they should first systematically collect all relevant information about the patient, then undertake a pathophysiological analysis and then establish a differential diagnosis. ${ }^{7-10}$ This is often not the way it works in practice, however. Three quarters of all hypotheses that GPs and internists use to guide the questions they ask to confirm hypotheses and to select the relevant information are generated in the first quarter of the consultation. ${ }^{11}$ Researchers found that hypotheses formulated earlier in the consultation are more likely to lead to correct diagnoses. ${ }^{4}$ This so-called hypothetico-deductive strategy is used by both experienced and inexperienced physicians. Other valuable tools that doctors could use to establish a diagnosis are medical decision-making rules, test characteristics and nomograms, but these are hardly applied in routine practice. ${ }^{12-14}$

We tried to find explanations for the discrepancy between what doctors are taught and what they practice. To this end, we identified the most common theories on diagnostic reasoning and analysed the differences between them, focusing on the clinical reasoning process of experienced GPs. We looked for this information in PubMed, in general practice journals like the Dutch Huisarts en Wetenschap and the Flemish Huisarts $\mathrm{Nu}$, as well as in books and PhD theses relating to this subject. The more recent literature in particular revealed a distinction between two approaches to this subject: more qualitative research in psychology and more quantitative research in medical decision-making theory. ${ }^{15-17}$ 


\section{Psychological theories}

Cognitive psychologists who have sought to explain the diagnostic process can be divided into two main categories: those who focus on the use of 'illness scripts' and those using the 'prototype model'.

\section{Illness scripts}

Dutch researchers have contributed considerably to research based on the 'information processing model', derived from cognitive psychology. This model is based on the metaphor that the human minds works like a computer, and assumes that knowledge is stored in multiple layers which gradually become interconnected. Studies have shown that this model is suitable for use in research into the development of medical expertise. ${ }^{18}$ The model is based on mental schemes, and the term illness script is one of the key concepts in this approach.

The process of developing and accumulating medical knowledge starts in the first years of medical school, when students learn about anatomy and physiology. As they gain more practical experience, they gradually develop the illness scripts. Such a script consists of three layers. The first layer comprises knowledge about factors that are associated - whether causally or not - with the development of a disease, including predisposing factors, risk factors, age and gender. Experienced GPs make intensive use of this so-called contextual information. ${ }^{5}$ The second layer consists of knowledge about the pathophysiological defects that characterise the disease. The third layer comprises knowledge about the corresponding symptoms and abnormalities. ${ }^{3,19}$ An example of a script is that of acute tightness of the chest in an overweight, tobaccoaddicted middle-aged man resulting from myocardial ischemia due to thrombotic processes in a coronary artery, with preexisting arteriosclerosis and a family history of cardiac problems. ${ }^{5}$ The main function of such scripts is that they allow a doctor to reduce a patient's story to medically identifiable explanations. As a doctor gains more and more practical experience, these three layers become ever more closely integrated. The more elaborate and the more closely interrelated these scripts are, the easier it is to activate them. Scripts are triggered by verbal and non-verbal cues from the patient. An example of a verbal cue is the patient's description of the nature of the pain in an acute coronary syndrome, while obesity as a risk factor may be a non-verbal cue. Experts compile basic biomedical knowledge - in this case anatomical and physiological knowledge about the heart - into essential concepts, such as thrombo-embolytic processes, and integrate it into clinical knowledge. ${ }^{20}$

Experienced doctors will immediately recognise this type of patient, and will also recognise this clinical picture in more complex situations. Whereas students tend to activate simple scripts from the basic medical knowledge they have been taught, experts use scripts based on more comprehensive knowledge. Their shorter search paths allow them to bypass biomedical explanations for the problem and establish a 
diagnosis immediately. It is only when they find no diagnosis that sufficiently explains the patient's complaints that experts also fall back on basic biomedical knowledge. Script theory provides a comprehensive, albeit complex, framework for knowledge about diseases, but aspects of clinical epidemiology, such as prior probability and tests characteristics, play a minor part in it.

\section{Prototypes}

Prototype theory is derived from semantics. ${ }^{21,22}$ According to this theory, we recognise a particular chair as such because it roughly corresponds to a 'chair' prototype that we have in our heads. Prototypes include the most common features of a particular category, in this case furniture that we can sit on. According to prototype theory, the medical knowledge stored in a doctor's memory is also structured around one or more diseases that are characteristic of the entire disease category. ${ }^{23}$ These prototypes form the clearest representatives of a disease category and serve as overall category labels to which less typical clinical pictures are linked. In the category of gastrointestinal disorders, for instance, duodenal ulcers and Crohn's disease prove to be more prototypical than malabsorption syndrome or Meckel's diverticulum. It is the typical disease of a particular category which hold the central position in this theory, and which doctors use to familiarise themselves with such a category, while the atypical diseases in the category play an important part in differential diagnostics. Medical handbooks categorise diseases differently, in an encyclopaedic manner. In this type of presentation, all diseases within a particular category meet all anatomical and physiological criteria. Research among GPs and medical students, however, has confirmed the presumed existence of prototypes. The GPs and students were found to use the same prototypes, which did not change, not even after several years of traditional refresher courses, ${ }^{24}$ showing that practice is stronger than theory. Prototypes act as recognisable patterns, as a kind of index to the knowledge network in clinician's head. Prototypes and other diseases within the same disease category are connected by cross-links, and the more experienced a physician is, the more numerous these cross-links are. A GP compares a patient's complaints and symptoms with the prototypes in his/her head, searching for a sufficient match, and using the cross-links to identify less typical clinical pictures within the same category. The findings described above have already been taken into account in at least one medical school curriculum. ${ }^{25}$ Although prototype theory is well able to explain the familiar phenomenon of pattern recognition, it offers few insights into the diagnostic significance of underlying anatomical and pathophysiological knowledge, unlike script theory. 


\section{Decision-making theory}

According to medical decision-making theory, the best way to decide upon a particular diagnosis is to apply mathematical and statistical rules to data. Instead of the more qualitative, psychological aspects of human thinking, this approach centres on the predictive value of symptoms and test results, and the probability of a particular disease.

\section{Bayes and likelihood ratio}

In their diagnostic process, GPs combine large amounts of knowledge they have accumulated during their training. They consider illness scripts or prototypes, which they then accept or reject. At the same time, considering diagnostic data also implies a quantitative process, namely assessing the probability that the patient has a particular disease. Thomas Bayes (1702-1761) described in mathematical terms how the probability of a particular conclusion - in our case a diagnosis - is altered by new data that become available, for instance from history-taking or examination.

Bayesian rule still plays a key role in diagnostics today, allowing 'hard' data, based on scientific evidence, to be combined with subjective assessments. Yet doctors often find it hard to integrate probabilities and other numbers into their diagnostic process. Concepts like sensitivity and specificity are often incorrectly used in interpreting test results. ${ }^{26}$ There is evidence to suggest that GPs find it easier to deal with information presented in different form, such as 'this symptom is five times as likely to occur in patients with this disease than in the rest of the patient population'.27-29 The epidemiological equivalent of this statement is the likelihood ratio: the likelihood ratio $\left(\mathrm{LR}^{+}\right)$of this particular symptom for this particular disease is 5 . The $L R$ value integrates sensitivity and specificity ( $\left(\mathrm{R}^{+}=\right.$sensitivity/1-specificity).

\section{Dealing with thresholds}

GPs will never completely rule out a diagnosis; rather, they will reassure a patient when the probability of the diagnosis is below a certain level, the exclusion threshold ${ }^{30-32}$ A GP's conclusion for a particular patient could thus be: considering all arguments, it seems unlikely that this patient is suffering from a coronary syndrome. GPs will start treatment or refer the patient to a specialist if the probability of a particular diagnosis exceeds a certain level, known as the action threshold: this is probably an infarction, so I need to refer this patient to a specialist. Between these two thresholds is the 'test area', the situation in which GPs will use or order specific investigations, like an ECG or blood tests for certain enzymes. In some cases, GPs may initiate treatment - for instance by prescribing salicylic acid - to reassure patients or themselves or to gain time in the hope that the clinical picture will become clearer or resolve spontaneously. In fact, the treatment itself may be used as a test procedure to 
assess the probability of a particular diagnosis, for instance by giving the patient nitroglycerin. The ability to deal with thresholds is thus an important aspect of a GP's competence and experience-based knowledge.

We should remember that the prior probability of disease is much lower in general practice than in specialist care. GPs and specialists are dealing with two different spectra of disease symptoms, because of the different developmental stages of the disease. This considerably affects the significance of symptoms and test results in the diagnostic process. ${ }^{33}$

\section{Predictive value of GPS}

GPs do not always establish an exact diagnosis; instead, they predict a particular outcome. $^{34,35}$ It has sometimes been said that there are really only two 'diagnoses', wich are referred to in Dutch as "pluis" and "niet-pluis", reflecting two types of gut feeling, namely a sense of reassurance and a sense of alarm. In a case of angina pectoris, these gut feelings have considerable predictive value for the GP. ${ }^{36}$ Patients' confidence in their GP is largely based on whether their predictions turn out to be correct, that is, on their GP's predictive value. A GP's decision-making process should be based on a correct estimation of the prevalence of complaints and symptoms, and their underlying diseases in the practice population. GPs think along several tracks at once, and decide how much weight to attach to the available information in the specific context. ${ }^{37-39}$ They do not think in numbers, odds or probabilities as continuous variables. They do not express the probability that a specific patient has suffered a myocardial infarction in numbers like $23 \%$ or $40 \%$, but think in terms of a low, reasonable or high probability. Vague notions like 'often', 'rarely' or 'never' acquire a more tangible meaning in practice. This means that doctors think in proportions, in categories of certainty, in orders of magnitude. The weight of an argument for or against a particular diagnosis is often implicit, although it can also be expressed in LR values.

\section{Discussion}

What is there to be learned from the above survey? We already knew that experienced GPs do not use different strategies than their inexperienced colleagues to solve diagnostic problems. The two psychological explanatory models discussed above show that the knowledge structure in an experienced GP's mind is more efficiently organised and that the search paths they follow to retrieve the appropriate knowledge are shorter. The theory of illness scripts shows that the contextual knowledge is very important for GPs in establishing a diagnosis. In everyday practice, much of the basic biomedical knowledge that is taught in medical school actually operates only in the background, as it has gradually become condensed into essential 
concepts. On the other hand, this basic knowledge can still be activated for the more challenging diagnostic problems.

Prototype theory has yielded the insight that the structure of the knowledge doctors have is such that the clinical pictures that are most easily recognisable in practice are located at the most accessible level of their knowledge network. These pictures serve as overall category labels to which less typical clinical pictures are linked. This means that the encyclopaedic knowledge gained from books during medical education has been reorganised as a result of experience they have gained in practice and made more easily accessible and applicable. Eczema is eczema because it looks like eczema, not necessarily because it satisfies a number of criteria from the corresponding ICPC code. Asthma is recognised from the pattern of periodic bouts of wheezing and/or coughing, rather than from a reversible peak flow measurement. The diagnostic code of bronchitis is chosen because what the doctor hears in auscultation sounds like bronchitis, not because it meets all criteria from a medical handbook. This difference may also be one of the reasons why the findings of randomised controlled trials (RCTs) are sometimes difficult to use in routine general practice, the so-called researchpractice gap. ${ }^{40,41}$ The eczema patients who are selected for inclusion in a RCT on the basis of scientific criteria only partly correspond to the prototypical eczema patients a GP sees.

Medical decision-making theory has focused our attention on more quantitative aspects of diagnostic reasoning: how does one arrive at a prediction, that is, an estimation of the probability that a patient has a particular disease? Experienced GPS would probably agree that they often - though implicitly - make predictions about a patient's prognosis: how are these patient's complaints likely to develop? Little is known, however, about the practical prognostic value of symptoms and test results in general practice. ${ }^{42,43}$ Threshold theory also describes what a doctor actually does, whether consciously or subconsciously. The results of research on these two theories have already been incorporated in some medical curricula. ${ }^{44}$ At the same time, however, it is not always easy for GPs to get used to the exact data used in the world of evidence-based medicine, as they tend to think in terms of proportional categories like 'often', 'possibly', 'rarely' and 'never'.

\section{The GP's contextual knowledge}

A typical asset of GPs is their contextual knowledge. This means that they combine knowledge about an individual patient with knowledge about the behaviour of particular diseases in other patients and background knowledge from the scientific literature to determine the prior probability, rather than basing it exclusively on prevalence data, as is often done. ${ }^{45,46}$ Experienced GPs are therefore characterised by their ability to correctly estimate the prior probability. ${ }^{47}$ It is perhaps the tension between epidemiological data and GPs' experience-based knowledge which explains why guidelines drawn up by professional bodies do not always appear useful in 
practice. $^{48,49}$ Such experience-based knowledge appears to be at least as important for the GP's diagnostic reasoning as book-derived knowledge and evidence from research. R. Brian Haynes, one of the founding fathers of evidence-based medicine, recently admitted that evidence from sound scientific research alone is not a sufficient basis for decisions. ${ }^{50}$ The doctor's expertise serves to integrate the individual patient's specific circumstances and their preferences and possibilities with the best available scientific evidence in order to arrive at a diagnostic or therapeutic decision. The Bayesian model fits in well with this clinical decision-making process, ${ }^{51}$ since what happens as a result of a GP's diagnostic process is that a hypothesis becomes more likely or less likely, rather than being proved or disproved.

Since GPs know their patients well, they have a great deal of contextual information. GPs who work in large out-of-hours services usually lack much of this information, which means that they benefit less from this diagnostic resource, which is essential for GPs. In addition, they are dealing with different incidence figures than those found in their everyday practice practice. These two factors make it much harder for them to correctly estimate the prior probability, and this increases the risk of diagnostic and/or prognostic errors. 


\section{References}

1. Tielens VCL, Mokkink H, Mesker P. The GP's medical-diagnostic approach [Het medisch-diagnostisch handelen van de huisarts]. Huisarts Wet 1985;28:44-8.

2. Okkes IM, Oskam SK, Lamberts H. From complaint to diagnosis [Van klacht naar diagnose]. Bussum: Uitg.Coutinho; 1998.

3. Feltovich PJ, Barrows HS. Issues of generality in medical problem solving. In:Tutorials in problembased learning. A new direction in teaching the health professions. Assen: Van Gorcum; 1984.

4. Barrows HS, Norman GR, Neufeld VR, Feightner JW. The clinical reasoning of randomly selected physicians in general medical practice. Clin Invest Med 1982;5:49-55.

5. Hobus P. GPs' expertise. [Expertise van huisartsen]. NUGI 741; 1994.

6. Dinant GJ, Van Leeuwen YD. Diagnosis and decision-making. Clinical diagnosis: hypothetico-deductive reasoning and other theoretical frameworks. In: Jones R, Britten N, Culpepper L, Gass D, Grol R, Mant D, Silagy C, editors. Oxford Textbook of Primary Medical Care.Oxford: Oxford University Press; 2004: 203-5.

7. Jacobs JCG, Cools BM, Postma CT. Clinical problem analysis as a methodology in the Nijmegen medical school curriculum to train problem-solving skills. [Klinische probleemanalyse als methodiek in het onderwijs in probleemoplossingsvaardigheden in het Nijmeegse geneeskundecurriculum]. Tijdschr v Med Ond 2002;21:64-74.

8. Houweling ST, Beenakker EAC, Levi MM, Stehouwer CDA, Gans ROB. Problem-oriented reasoning in internal medicine. [Probleemgeorienteerd denken in de interne geneeskunde]. Leusden: De Tijdstroom; 2001.

9. Grundmeijer HGLM, Reenders K, Rutten GEHM. The process of medicine, from complaint to therapy [Het geneeskundig proces, van klacht naar therapie]. Maarssen: Elsevier/Bunge; 2004.

10. Postma CT, Lutterman JA, Stuyt PM, De Vries Robbe PF, Van der Meer JWM. Clinical reasoning and decision-making in practice. A patient with diarrhoea and a patient with dyspnoea. [Klinisch denken en beslissen in de praktijk. Een patiente met diarree en een patiente met dyspnoe]. NTvG 1996;140:1618-20.

11. Elstein AS, Shulman L, Sprafka S. Medical Problem Solving: an analysis of clinical reasoning. Cambridge, Mass.: Harvard University Press; 1978.

12. Reid MC, Lane DA, Feinstein AR. Academic calculations versus clinical judgments: practicing physicians' use of quantitative measures of test accuracy. Am J Med 1998;104:374-80.

13. Zaat JOM. How many general practitioners will fit on a ROC curve? The impossibility of medical decision analysis in daily practice. Huisarts Wet 1993;36 (Suppl):54-7.

14. Dinant GJ, De Maeseneer J, Derese A. How many ROC curves fit into one general practitioner? The paradox between medical decision making and daily general practice. Huisarts Wet 1993;36 (Suppl):58-61.

15. Elstein AS, Schwarz A. Clinical problem solving and diagnostic decision making: a selective review of the cognitive literature. BMJ 2002;324:729-32.

16. Norman GR. The epistemology of clinical reasoning: perspectives from philosophy, psychology, and neuroscience. Acad Med 2000;75(10 Suppl):S127-S135.

17. Elstein AS. Clinical problem solving and decision psychology: comment on "the epistemology of clinical reasoning". Acad Med 2000;75(10 Suppl):S134-S136.

18. Boshuizen HPA. Developing medical expertise, a cognitive psychology approach. [De ontwikkeling van medische expertise, een cognitief-psychologische benadering]. 1989.

19. Gulmans J. Learning to establish diagnoses: conceptualisation and problem-solving in medical and paramedical education. [Leren diagnosticeren: begripsvorming en probleemoplossen in (para-) medische opleidingen]. Amsterdam: Thesis Publishers; 1994.

20. Van de Wiel M. Knowledge incapsulation. Wageningen: Ponsen \& Looijen; 1997.

21. Rosch E. Cognitive representations of semantic categories. Journal of experimental psychology: general 1975;104:192-233.

22. Rosch $E$, Mervis $C B$. Family resemblance: studies in the internal structure of categories. Cognitive Psychology 1975;7:573-605.

23. Bordage G. Elaborated knowledge: a key to successful diagnostic thinking. Acad Med 1994;69:883-5. 
24. Bordage G, Lemieux M. Semantic structures and diagnostic thinking of experts and novices. Acad Med 1991;66(9 Suppl):S70-S72.

25. Custers EJ, Stuyt PM, De Vries Robbe PF. Clinical problem analysis (CPA): a systematic approach to teaching complex medical problem solving. Acad Med 2000;75:291-7.

26. Berwick DM, Fineberg HV, Weinstein MC. When doctors meet numbers. Am J Med 1981;71:991-8.

27. Attia J. Moving beyond sensitivity and specificity: using likelihood ratios to help interpret diagnostic tests. Australian prescriber 2003;26.

28. Steurer J, Fischer JE, Bachmann LM, Koller M, Ter Riet G. Communicating accuracy of tests to general practitioners: a controlled study. BMJ 2002;324:824-6.

29. Bachmann LM, Steurer J, Ter Riet G. Simple presentation of test accuracy may lead to inflated disease probabilities. BMJ 2003;326:393.

30. Van de Ende J, Derese A, De Wachter J. Thresholds: the bounderies of diagnostics [Drempels: de grenzen van het diagnostisch actieterrein]. Huisarts Nu 1996;25:315-21.

31. Pauker SG, Kassirer JP. The threshold approach to clinical decision making. N Engl J Med 1980;302: 1109-17.

32. Habbema JD. Clinical decision theory: the threshold concept. Neth J Med 1995;47:302-7.

33. Knottnerus JA. Interpreting diagnostic data. [Interpretatie van diagnostische gegevens]. Maastricht: 1986.

34. Van der Velden HGM. Diagnosis or prognosis? The significance of epidemiology in GPs' procedures. [Diagnose of prognose? De betekenis van de epidemiologie voor het handelen van de huisarts]. Huisarts Wet 1983;26:125-8.

35. Bremer GJ. GP and diagnosis. [Huisarts en diagnose]. Huisarts Wet 1983;26:23-6.

36. Buntinx F, Truyen J, Embrechts P, Moreel G. Chest pain. From complaints to diagnosis. [Pijn op de borst. Van klacht naar diagnose]. Huisarts Nu 1989;18:243-50.

37. Van de Ende J, Derese A, Van Puymbroek H, Boeckx J. Arguments and patients: Bayes' theorem [Argumenten en patienten: het theorema van Bayes]. Huisarts Nu 1996;25:306-14.

38. Van den Ende J, Derese A, Lemiengre M. The power of arguments: the value of diagnostic data [De kracht van een argument: de waarde van diagnostische gegevens]. Huisarts Nu 1996;25:298-305.

39. Van de Ende J, Derese A, Vanderstuyft P, Janssen P. Scales: logarithmic evidence to support GPs' intuition [Schalen: intuitie van de huisarts logaritmisch onderbouwd]. Huisarts Nu 1996;25:322-8.

40. Knottnerus JA, Dinant GJ. Medicine based evidence, a prerequisite for evidence based medicine. BMJ 1997;315:1109-10.

41. Robinson P, Heywood P. What do GPs need to know? The use of knowledge in general practice consultations. Br J Gen Pract 2000;50:56-9.

42. Feinstein AR. Misguided efforts and future challenges for research on "diagnostic tests". J Epidemiol Community Health 2002;56:330-2.

43. Knottnerus JA. Challenges in dia-prognostic research. J Epidemiol Community Health 2002;56:340-1.

44. Van Puymbroeck H, Remmen R, Denekens J, Scherpbier A, Bisoffi Z, Van den Ende J. Teaching problem solving and decision making in undergraduate medical education: an instructional strategy. Med Teach 2003;25:547-50.

45. Van Leeuwen YD, Baggen JL. Medical decisions: correct and sensible? [De medische beslissing: juist en zinnig?]. Huisarts Wet 2002;45:66-9.

46. Van Leeuwen YD, Baggen JL. GP and illness or GP and patient? [Huisarts en ziekte of huisarts en patient?]. Huisarts Wet 2001;44:605-8.

47. Van Leeuwen YD. GPs' experential knowledge. [De ervaringskennis van huisartsen]. Huisarts Wet 1998; 41:80-4.

48. De Jongh TOH, Van Ruijven AGH. Why do NHG guidelines not always fit in with GPs' diagnostic approach? [Waarom sluiten NHG-standaarden onvoldoende aan bij de diagnostiek van de huisarts?]. Huisarts Wet 2000;43:340-6.

49. Bugel P. Patients and medical science. Guidelines have various disadvantages for patients. [Patient en wetenschap. Standaarden hebben voor de patient allerlei nadelen]. MC 2003;58:465-8.

50. Haynes RB, Devereaux PJ, Guyatt GH. Clinical expertise in the era of evidence-based medicine and patient choice. ACP J Club 2002;136:A11-A14.

51. Spiegelhalter DJ, Myles JP, Jones DR, Abrams KR. Methods in health service research. An introduction to bayesian methods in health technology assessment. BMJ 1999;319:508-12. 


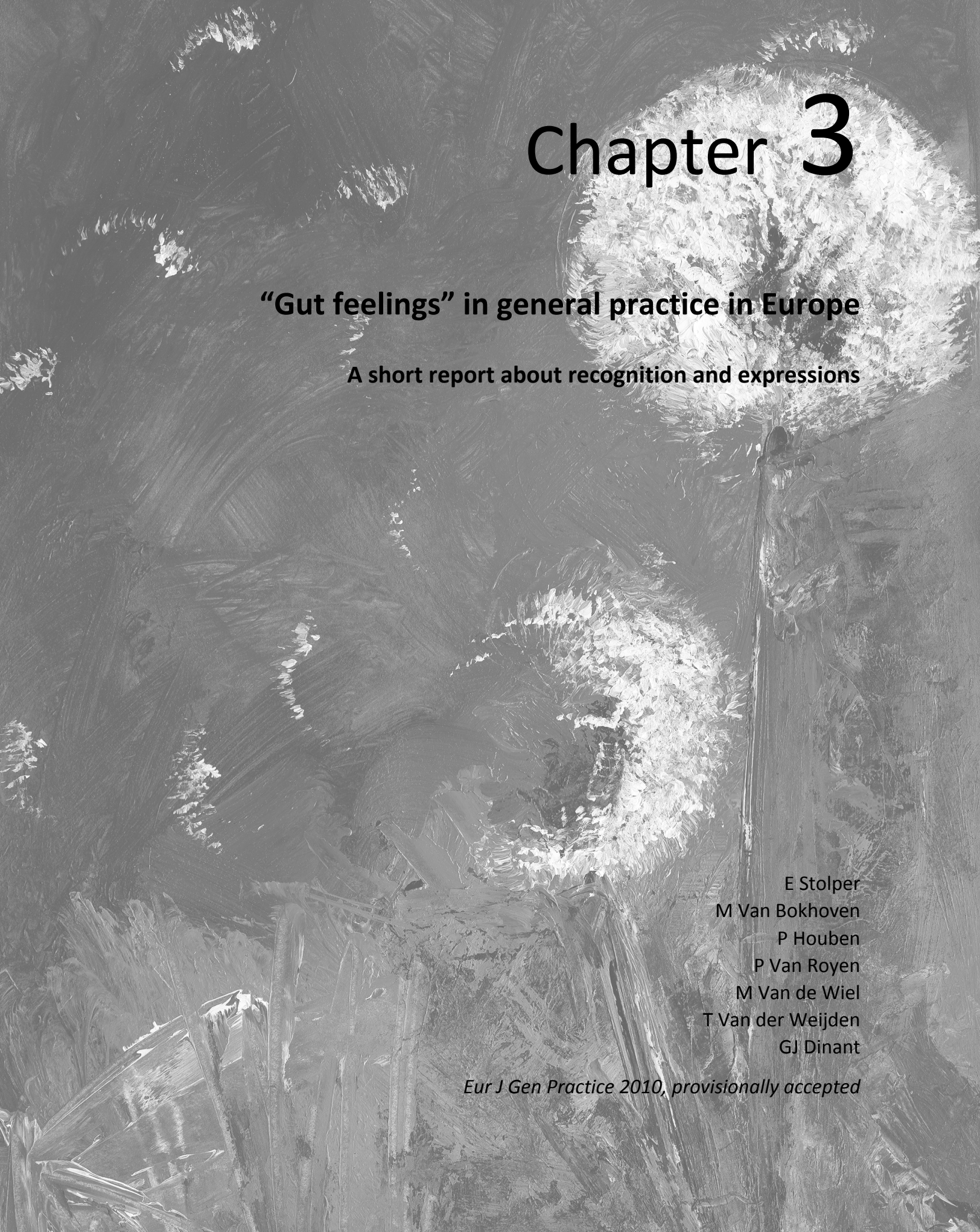


\section{Abstract}

\section{Introduction}

Most general practitioners (GPs) in the Netherlands and in Flanders (Belgium) are familiar with that special feeling during certain consultations: "There's something wrong here, though I have no specific indications yet". This sense of alarm alerts the doctor, activates the diagnostic process and induces him or her to initiate specific management to prevent serious health problems.

\section{Objective}

We wanted to know if this sense of alarm is a typical phenomenon among Dutch-speaking GPs or is also recognised by GPs elsewhere in Europe.

\section{Methods}

A short questionnaire survey was held among $128 \mathrm{GPs}$ in countries ( $\mathrm{N}=28$ ) included in the European General Practitioners Research Network (EGPRN). GPs were asked if they recognised our description of the sense of alarm and if they use a typical phrase in their language to express this uneasy feeling.

\section{Results}

We received 30 replies from GPs in 16 European countries, plus Israel and South Africa. They all recognised our description and 25 GPs reported phrases or typical expressions in their own language. The GP's uneasy feeling was sometimes experienced as a bodily sensation.

\section{Conclusion}

All replies show clear that the sense of alarm is a familiar phenomenon in general practices in Europe. We propose to use the English phrase "gut feelings" in further research reports. 


\section{Introduction}

Research has shown that most general practitioners (GPs) in the Netherlands and in Flanders (Belgium) are familiar with that special feeling in some consultations: "There's something wrong here, though I have no specific indications yet". This sense of alarm means that a GP perceives an uneasy feeling as he or she is concerned about a possible adverse outcome. Something vague and non-specific in the patient's story or in the presentation alerts the doctor, activates the diagnostic process and induces him or her to initiate if possible specific management to prevent serious health problems. Doctors in the Netherlands and Flanders use a typical Dutch expression for this feeling, viz. "niet-pluis", a phrase that cannot be translated easily. The literature offers hardly any information about this topic. It is sometimes specified as "a useful warning light, which suddenly lights up to announce that there is something unusual". ${ }^{1}$ It has also been described as "a wrong feeling as a way to distinguish urgent from non urgent" and "a rough assessment of the situation to identify emergency problems". ${ }^{2,3}$ A review about diagnostic reasoning made no mention of a sense of alarm at all. ${ }^{4}$ Nevertheless, since we believe this sense of alarm can have important diagnostic value in general practice we started qualitative research to describe the nature and diagnostic properties of this feeling. ${ }^{5,6}$ We distinguished a sense of alarm and a sense of reassurance. A sense of alarm is defined as an uneasy feeling perceived by a GP as he/she is concerned about a possible adverse outcome, even though specific indications are lacking: There's something wrong here. This activates the diagnostic process by stimulating the GP to formulate and weigh up working hypotheses that might involve a serious outcome. A sense of alarm means that, if possible, the GP initiates specific management to prevent serious health problems. By contrast, a sense of reassurance was defined as a secure feeling perceived by a GP about the further management and course of a patient's problem, even though the doctor may not be certain about the diagnosis: Everything fits in.

We decided to research this phenomenon further, and to compare our results with the experience of GPs in other countries. We wanted to know if this sense of alarm is a phenomenon that is typical of Dutch speaking GPs (since they use a special phrase for it) or whether it would also be recognised by other GPs in Europe and if so, which words they would use to refer to it. We also wanted to find a clear and recognisable English phrase for these feelings, to allow us to compare GPs' experience in Europe and their definitions of the sense of alarm and the sense of reassurance in future research.

\section{Method}

A short questionnaire survey was drafted by two authors (ES and PVR) and sent to 128 GPs in countries $(\mathrm{N}=28)$ included in the European General Practitioners Research 
Network (EGPRN). In October 2005, the questionnaire was sent to the EGPRN listserver (address: EGPRN@yahoogroups.com), a discussion forum with currently about 100 members, who are national representatives and key persons in their country, mainly in Europe, but also in Israel and South Africa. To increase the response rate, the questionnaire was sent out again in January 2006, in personal e-mails to 28 EGPRN GPs in those European countries from which few or no responses had been received to the first mailing on the EGPRN listserver. GPs were asked if they recognised our description of the sense of alarm (see Text box 3.1) and if they used specific phrases in their language to express this uneasy feeling. Responses were to be given in English except for the typical phrases, and were analysed at the level of individual GPs as we did not aim for consensus within countries.

Text box 3.1 Description and questions.

Probably every Dutch GP knows that special sense from some consultations: "there's something wrong with this patient but I don't know exactly what. I have to do something with this patient because waiting longer is bad for him or her". It is an unspecific sense, non-analytical but important to be recognised. Some vague in the patient's story or in the presentation triggers the doctor and alerts him. It has something to do with prognosis.

In the Netherlands we use a typical expression for this sense: "niet-pluis". Recently we started research to examine the value of this feeling, the diagnostic properties. In the literature unfortunately almost nothing can be found about this topic.

Therefore we would like you to answer the following questions, if possible:

1. Do you recognise this special sense?

2. Do you have in your language an expression or description for this feeling? If yes, please write here which expression or description. And what is the translation in English?

\section{Results}

We received 30 replies from GPs in 16 European countries, and in Israel and South Africa (see Table 3.1). They all recognised our description, and 25 of them offered phrases or typical expressions in their own language. Ten respondents described that they perceived this uneasy feeling as a bodily sensation in the gut, the stomach or the bones or, metaphorical, as a "smell". Although the response rate $(24 \%)$ was rather low, it seems justified to conclude that the sense of alarm is not a typically Dutch topic in the diagnostic process in general practice. 
Table 3.1 'Sense of alarm' and comparable expressions in Europe.

\begin{tabular}{|c|c|c|}
\hline Country & Recognition & Expression/description \\
\hline Belgium & Yes & Pluis en niet-pluis. \\
\hline Bulgaria & Yes & No specific expression. \\
\hline Bulgaria & Yes & Intuition. \\
\hline Croatia & Yes & Intuition, sixth sense. \\
\hline Denmark & Yes & $\begin{array}{l}\text { Min sjette sans sagde mig = My sixth sense tells me something is wrong. } \\
\text { Noget i min mave fortalte mig = something in my stomach told me or my } \\
\text { gut feeling told me. } \\
\text { Et eller andet sagde mig at noget er galt = something tells me something is } \\
\text { wrong. }\end{array}$ \\
\hline France & Yes & Sentiment d'ètrangetè = a sense of something strange. \\
\hline France & Yes & Peut-être intuition ou intime conviction = one's innermost conviction. \\
\hline France & Yes & $\begin{array}{l}\text { Mauvais presentiment ou mauvaise premonition = ominous feeling or a } \\
\text { bad premonition. }\end{array}$ \\
\hline Germany & Yes & Alarmgefühl = sense of alarm. \\
\hline Germany & Yes & Hier stimmt was nicht = there's something wrong here. \\
\hline Germany & Yes & Ahnung. Gefühl = suspicion, feeling. \\
\hline Greece & Yes & 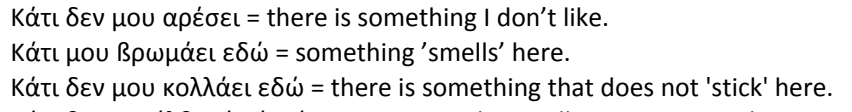 \\
\hline Greece & Yes & 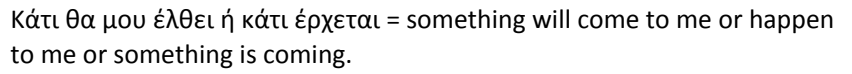 \\
\hline Hungary & Yes & $\begin{array}{l}\text { Megmagyarazkatatlan allapotromlas = unexplained detoriation. } \\
\text { Valami nem tetstik = something dislike. }\end{array}$ \\
\hline Israel & Yes & Gut feeling, abdominal sensations. \\
\hline Israel & Yes & No expression in Hebrew; sixth sense. \\
\hline Italy & Yes & No. \\
\hline Italy & Yes & Brutto presentimento $=$ an uneasy premonition. \\
\hline Italy & Yes & No specific expression. \\
\hline Malta & Yes & Ixxomm xi haga = something 'smells'. \\
\hline Norway & Yes & $\begin{array}{l}\text { Magefǿlelse = feeling in my stomach. } \\
\text { Noe som ikke stemmer = something that doesn't fit in. } \\
\text { Pasienten virker syk = patient seems ill. }\end{array}$ \\
\hline Norway & Yes & Dårlig magefølelse = bad feeling in the stomach. \\
\hline Portugal & Yes & sexto sentido = sixth sense. \\
\hline Romania & Yes & No specific expression. \\
\hline South Africa & Yes & Gut feel. Instinct. \\
\hline $\begin{array}{l}\text { Serbia/ } \\
\text { Montenegro }\end{array}$ & Yes & $\begin{array}{l}\text { Neobjasnjivo zdravstveno stanje = unexplained health condition. } \\
\text { Svestan opasnosti = alert to danger. } \\
\text { Potencijalno opasno zdravstveno stanje = potential dangerous health } \\
\text { condition. }\end{array}$ \\
\hline Switzerland & Yes & Mon petit doigt me dit, intuition = my little finger says. \\
\hline Turkey & Yes & Koku var = this has a smell, this case 'smells'. \\
\hline UK & Yes & $\begin{array}{l}\text { Gut feeling. } \\
\text { Uncertain feeling but needing to do something. }\end{array}$ \\
\hline UK & Yes & I have a feeling in my bones. \\
\hline UK & Yes & $\begin{array}{l}\text { Clinical hunch or sixth sense that something serious is going on or clinical } \\
\text { intuition. }\end{array}$ \\
\hline
\end{tabular}


Seven of the respondents added commentaries. A Danish GP reported about the necessity of teaching young doctors to trust this "fingertip" feeling or the "sense in your nose". Norwegian GPs described it as a kind of intuition, based on expertise, pattern recognition, bodily empathy or tacit knowledge. Gut feelings are not mystical, despite the fact that GPs are not fully aware of all of the information they absorb and process in a clinical situation. The sense of alarm has something to do with coping with uncertainty, as one GP from the UK wrote.

\section{Conclusion}

The 30 replies show that the sense of alarm that is so well-known in Dutch and Flemish general practice is a common phenomenon in general practice all over Europe and beyond. It seems worth while to establish an international research agenda to validate the concept and to estimate its value for daily practice routine and education. Since the results of our survey show a frequent link to bodily sensations, we propose to use the English phrase "gut feelings" in further research reports to represent the twin concepts of a sense of alarm and a sense of reassurance. 


\section{References}

1. Hull F. The consultation process. In: Sheldon M, Brooke J, Rector A, editors. Decision Making in General Practice.London: Macmillan; 1985:13-26.

2. Andre M, Borgquist L, Foldevi M, Molstad S. Asking for 'rules of thumb': a way to discover tacit knowledge in general practice. Fam Pract 2002;19:617-22.

3. Boreham NC. The dangerous practice of thinking. Med Educ 1994;28:172-9.

4. Elstein AS, Schwarz A. Clinical problem solving and diagnostic decision making: a selective review of the cognitive literature. BMJ 2002;324:729-32.

5. Stolper CF, Van Bokhoven MA, Houben PHH, Van Royen P, Van de Wiel M, Van der Weijden T, Dinant G.J. The diagnostic role of gut feelings in general practice. A focus group study of the concept and its determinants. BMC Fam Pract 2009;10.

6. Stolper CF, Van Royen P, Van Bokhoven MA, Houben PHH, Van de Wiel M, Van der Weijden T, Dinant GJ. Consensus on gut feelings in general practice. BMC Fam Pract 2009;10:66. 

$+2$

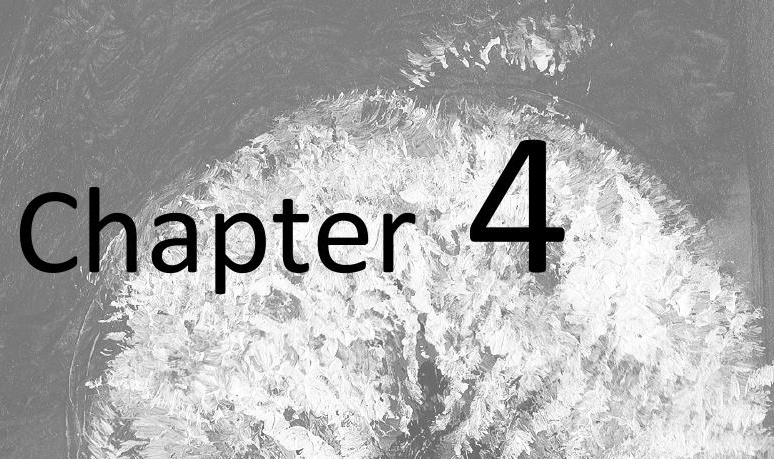

The diagnostic role of gut feelings in general practice

A focus group study of the concept and its determinants 


\section{Abstract}

\section{Introduction}

General practitioners (GPs) sometimes base clinical decisions on gut feelings alone, even though there is little evidence of their diagnostic and prognostic value in daily practice. Research into these aspects and the use of the concept in medical education require a practical and valid description of gut feelings. The goal of our study was therefore to describe the concept of gut feelings in general practice and to identify their main determinants.

\section{Methods}

Qualitative research including four focus group discussions. A heterogeneous sample of 28 GPs. Text analysis of the focus group discussions, using a grounded theory approach.

\section{Results}

Gut feelings are familiar to most GPs in the Netherlands and play a substantial role in their everyday routine. The participants distinguished two types of gut feelings, a sense of reassurance and a sense of alarm. In the former case, a GP is sure about prognosis and therapy, although they may not always have a clear diagnosis in mind. A sense of alarm means that a GP has the feeling that something is wrong even though objective arguments are lacking. GPs in the focus groups experienced gut feelings as a compass in situations of uncertainty and the majority of GPs trusted this guide. We identified the main determinants of gut feelings: fitting, alerting and interfering factors, sensation, contextual knowledge, medical education, experience and personality.

\section{Conclusion}

The role of gut feelings in general practice has become much clearer, but we need more research into the contributions of individual determinants and into the test properties of gut feelings to make the concept suitable for medical education. 


\section{Introduction}

Most general practitioners (GPs) would recognise that feeling of sudden heightened awareness or alarm, which sometimes emerges during a consultation: "There's something wrong with this patient but I don't know exactly what. I have to do something because a delay can be harmful". It is a non-specific sense of alarm, which may perhaps seem difficult to explain rationally, an almost visceral sense that something serious may be wrong with the patient. Something vague in the patient's story or in the presentation triggers an alert. Sometimes GPs base their clinical decision on this gut feeling alone, even though there is little evidence of the diagnostic value of gut feelings in general practice. Hardly anything can be found about this phenomenon in the medical literature, which mainly focuses on problemsolving and decision-making in diagnostic processes. ${ }^{1-5}$ Sometimes it is specified as a useful warning light, which suddenly lights up to announce that there is something unusual. ${ }^{6}$ It has also been described as "a wrong feeling as a way to distinguish urgent from non urgent" and "a rough assessment of the situation to identify emergency problems". ${ }^{7,8}$ Primary care research into the diagnostic value of signs and symptoms for serious infections in children has identified the physician's feeling that "something is wrong" as most important. ${ }^{9}$ A GP's first impression about the seriousness of chest pain is highly reliable. ${ }^{10}$ Medical intuition or a 'clinical nose' in diagnostics seems powerful and real, but poorly defined. ${ }^{11}$ Despite this, gut feelings were not mentioned in reviews of diagnostic reasoning and medical expertise. ${ }^{1,2}$ Our literature search revealed that more is known about the role of gut feelings in neonatal intensive care units and in emergency care settings. ${ }^{12-14}$ In this world, full of sophisticated technology, gut feelings appear to be taken seriously because they sometimes alert nurses and doctors to take important action earlier than machines do. ${ }^{15,16}$ However, studies about gut feelings and intuition in nursing primarily remain at conceptual and exploratory levels. ${ }^{17-20}$

Although gut feelings thus seem to have a place in the GP's diagnostic process, what is lacking is studies about the validity of this diagnostic instrument. ${ }^{21}$ Gut feelings are difficult to examine because they are non-analytical and not easily measurable. But if we were able to find evidence of their positive role in general practice, it could be worth examining the potential for including this aspect of diagnosis and management in medical education. However, research into the value of gut feelings requires an accessible and valid description. In addition, we assumed that a GP's experience and contextual knowledge would be important determinants of the development of gut feelings. In this article we report how we tried to formulate the concept of gut feelings and how we identified the main determinants of such easily recognised but poorly described personal responses to certain clinical situations. 


\section{Methods}

\section{Design}

A qualitative approach was chosen because this type of research would enable us to focus on the meaning and significance that GPs attach to gut feelings and opinions about them. We decided to work with focus groups and not with personal interviews since the members of a focus group respond directly to each other, generating more questions about the topic at hand and sharing common experiences while a moderator probes for further explanations. ${ }^{22,23} \mathrm{~A}$ Delphi consensus procedure was not suitable at this stage because of the lack of knowledge about this topic. We opted for purposive sampling to recruit members for the groups, to obtain a representative distribution of factors assumed to be related to the subject, such as experience, gender and urban or rural location of the practice, and to maximize the exploration of different perspectives. We asked the teaching staff at three Departments of General Practice to name GPs in the surrounding areas who were not employed by a university and who might be interested in reflecting on diagnostic thinking. Interested GPs were invited by phone to participate in one of our three planned focus groups. We sent those who agreed to do so written information, without disclosing the exact purpose of the focus groups, so as to avoid bias. For each group of about 7 members, we contacted 10-15 GPs working in the same region. After three focus group sessions had taken place, we concluded that they had included too few inexperienced female physicians. We therefore composed a fourth group, consisting of female GPs who were working part-time and had limited experience as a GP. We developed a scenario in advance, not to steer the discussion but to ensure that all topics relating to our research subject would come up in the discussions (see Text box 4.1). The scenario was adapted after each group because some topics were not clarified satisfactorily. For instance, if gender was not spontaneously discussed, it was only included as a topic at the end of the third group meeting.

The sessions were chaired by an experienced and independent moderator. The moderator introduced the subject of our research as a discussion about the nonanalytical aspects of GPs' diagnostic thinking, ${ }^{24,25}$ without mentioning the phrase gut feelings. However, each group spontaneously talked about gut feelings shortly after the group discussions started. The group discussions were tape-recorded and transcribed, and we checked the text. After each meeting there was a debriefing with the moderator and we adapted the scenario to focus on unclear aspects. Data saturation was reached after four group sessions. 
Text box4.1 Some important questions in the scenario.

- The aim of this study is to collect information on the way you approach the diagnostic process. When you were training to become a doctor, you learned to diagnose patients using systematic frameworks and questions. In actual practice, however, doctors don't always seem to use such a structured approach, as their gut feelings and practical experience also play an important part. We are especially interested in this non-analytical aspect. What comes to mind when you think about the non-analytical aspects of establishing a diagnosis?

- What happens if your gut feelings start to play a part in the diagnostic process? How do you deal with this? Can you indicate what cues or key symptoms trigger your intuition?

- To what extent do you think this is influenced by professional experience?

- (if this has not yet come up in the discussion) What are your feelings about the 'sense of reassurance versus sense of alarm' distinction? Are these concepts useful in your opinion?

- Can you think of a case in which you had a sense of reassurance which turned out to be unjustified?

- We would like to arrive at a description of such gut feelings (sense of reassurance versus sense of alarm). In your opinion, what elements would definitely have to be included in such a description?

- $\quad$ (after the first group) People in the previous group said that gut feelings are a key element in a doctor's professional behaviour. What do you think of that?

- $\quad$ (after two groups) Do you think the concept of gut feelings (distinguishing between a sense of reassurance and a sense of alarm) can be taught to students?

- $\quad$ (after two groups) In terms of gut feelings, do you think there is a difference between male and female GPs?

- (after two groups) The previous sessions have given us the idea that these gut feelings are more than just feelings, as they also depend on knowledge. What is your opinion about this?

\section{Analysis}

Since hardly anything was known about the diagnostic role of gut feelings in general practice, we used the grounded theory approach ${ }^{26,27}$ where data are jointly collected, coded and analyzed, while deciding which data belong to which category. We started with an open coding of the transcripts and attached codes to any quote that could be important, in the light of our research questions. Subsequently, we iteratively developed new codes and ideas and compared them with old data. This specific approach is appropriate when studying a previously unresearched phenomenon. It enabled us to construct a theoretical concept, while continuously comparing old data with new ones gathered for this specific purpose. The transcripts were coded by three independent researchers (ES, LVB, TVdW), who reached consensus on the selection of meaningful codes afterwards. In the next phase - known as axial coding - we looked for relations between codes and developed categories and themes to build a grounded theory about gut feelings. Each new step was initiated after agreement in the research group. The analysis was facilitated by the Atlas-ti software program. The text was then reread to reflect on the categories we had developed. Finally, we did a member check by sending the participants a summary of our research findings and incorporating their suggestions for adjustment. 


\section{Ethical approval}

Participants were asked to give their informed consent at the start of each focus group session. Since no patients were involved and GPs were only asked about their opinions and perceptions, this research did not fall under the Dutch Medical Research Involving Human Subjects Act (WMO) or the Embryos Act, so that no ethical permission was required.

\section{Results}

\section{Study population}

Four focus group sessions took place, with a total of 28 GPs participating. The characteristics of the GPs met our criteria (see Table 4.1). Two GPs who had accepted the invitation did not turn up, without giving a reason.

Table 4.1 Characteristics of members of focus groups.

\begin{tabular}{|c|c|c|c|c|c|c|c|c|c|c|c|c|c|}
\hline & $\mathrm{N}$ & $M$ & $\mathrm{~F}$ & Age & $\begin{array}{c}\text { Experience } \\
<6 \text { years }\end{array}$ & $\begin{array}{l}\text { Experience } \\
>6 \text { years }\end{array}$ & $\begin{array}{c}\text { Experience, } \\
\text { mean no. of } \\
\text { years }\end{array}$ & Urban & Rural & $\begin{array}{c}\mathrm{GP} \\
\text { trainer }\end{array}$ & $\begin{array}{c}\text { Single- } \\
\text { person } \\
\text { Pract. }\end{array}$ & $\begin{array}{l}\text { Group } \\
\text { Pract. }\end{array}$ & $\begin{array}{l}\text { Part } \\
\text { time }\end{array}$ \\
\hline F1 & 6 & 5 & 1 & 45.6 & 2 & 4 & 12.6 & 0 & 6 & 0 & 3 & 3 & 2 \\
\hline F2 & 6 & 4 & 2 & 49.2 & 0 & 6 & 17.8 & 4 & 2 & 5 & 4 & 2 & 0 \\
\hline F3 & 9 & 8 & 1 & 50.3 & 0 & 9 & 17.4 & 5 & 4 & 5 & 3 & 6 & 2 \\
\hline F sub-total & 21 & 17 & 4 & 48.6 & 2 & 19 & 15.9 & 9 & 12 & 10 & 10 & 11 & 4 \\
\hline $\mathrm{F} 4$ & 7 & 0 & 7 & 34.7 & 7 & 0 & 4.1 & 3 & 4 & 1 & 0 & 7 & 7 \\
\hline F total & 28 & 17 & 11 & 45 & 9 & 19 & 13 & 12 & 16 & 11 & 10 & 18 & 11 \\
\hline
\end{tabular}

\section{Describing gut feelings}

Gut feelings were recognized in all focus groups as a phenomenon familiar to most GPs in the Netherlands and playing an important role both in routine practice and during out of hours care. Two types of gut feelings were mentioned by the participants: a sense of alarm and a sense of reassurance. The participants often perceived the sense of alarm as a physical sensation in the abdomen or the heart (a) (see Text box 4.2 quotes). Three elements were seen as important in describing a sense of alarm: the feeling that there appears to be something wrong without the doctor having objective arguments, a distrust of the situation because of uncertainty about the prognosis of the complaints and the need for some kind of intervention to prevent serious health problems (b). When they experienced a sense of reassurance, the GPs were sure about the prognosis and therapy, even in the absence of a diagnosis (c). Gut feelings were not related to specific diseases but to the certainty of what a GP had to do. A GP can have a sense of reassurance when he sends one patient with chest pain home but also when he refers another to hospital. GPs were 
not always conscious of their sense of reassurance at the time they made decisions. It was often identified in retrospect (d). Sometimes a GP experienced a gradually growing sense of alarm, but it might also have a sudden onset, after which it could fade away in the course of the encounter. Several determinants of gut feelings could be distinguished; these are discussed below. Based on our findings we visualized the interrelated determinants in a network (see Figure 4.1: determinants of gut feelings in general practice). The outcome did not differ fundamentally between the groups.

Text box 4.2 Quotes.

\section{Defining gut feelings}

a. Where I feel this? Literally in my guts; it's an actual physical sensation, telling me something's wrong. (V1570) I can actually feel my heartbeat start to accelerate. (V1605).

b. It's the feeling that, in spite of all rational arguments and considerations and weighing up all the information you've obtained from history-taking, physical examination and perhaps some additional diagnostics, there's still this underlying feeling of something not fitting in, something being amiss. I can't really grasp it, or put a name on it, and there are all kinds of arguments to say there's nothing wrong, and yet as a GP you still have this sense, which you could call a sense of alarm, of something being not right. (M1444) But to me, this gut feeling means that you're very soon aware whether something is wrong or not. That's the gut feeling. (N591) Because you see a lot of patients with complaints, and with most of them your gut feeling reassures you there's no serious problem. And then suddenly there's one who's not OK and you get this feeling a sort of tingling in your spine. (V1599)

c. You've got your diagnosis and it all fits and even if they feel very sick you can say you'll be OK in the morning. So you are backed up by a diagnosis that actually helps you. It all fits, so you're reassured, even though the patient feels very sick. (V2008) But in your everyday practice routine, it's often enough to, say, postpone it or to say it's so recent or things are going OK or whatever, so that means you're working in a grey area, without having an actual diagnosis, but a general sense of what direction to go, or this can wait, or I need to see this patient again. So you're in a grey area: there's as yet no clear diagnosis but you still take a decision. That sort of thing. ( M0410)

d. Nine out of ten times, or perhaps even ninety-five out of a hundred times, you're not aware of this sense of reassurance; it's the sense of alarm that you're aware of. (V1215). At a certain moment, it becomes a matter of knowing, this gut feeling of alarm or reassurance, you just know (N0626).

\section{Fitting or alerting factors}

e. I always think: does this presentation fit in, with the complaints, and with what you find in your examination. Do they form a consistent picture or are there aspects that don't fit in? That make you think wait a minute, this isn't right. And how can I look at it differently? That's when you start to look into it further. (H0501).

f. These people come and, as it were, sing their song. It's usually the same song, but if it changes, that's when you sit up and look at it in a completely different way. (N0385).

\section{Contextual knowlegde and interfering factors}

g. You also have the frame of reference of the family that a patient comes from, which means you notice when they're different or present in an unusual way or they may say well, this time there's really something wrong with me, or perhaps that's precisely what they do not say, whereas they normally do. So there's something different and that has some significance, in light of what you already know about them. (M0438).

h. When I'm angry like that, my antennae don't work, and that means I'm not being a good doctor to this patient. I'm convinced of that. I really mess up, because my gut feeling no longer works. (N1024).

i. I think my rational considerations, my lists and all that, are much more valid than my initial intuition. I tend to ignore that. (M0747). 


\section{Medical education and experience}

j. It's not what I learned at university; I was taught to work on the basis of lists. (M1296)

k. And I think you can teach an trainee GP this by saying to them wait a minute, stop thinking of numbers and things like that, what about your feelings? What do your feelings tell you? (V2984).

I. Your GP training can provide you with a number of 'handles' that can help you develop this feeling. One of these handles is self-reflection. But it's also a matter of personality: if you're not willing to engage in introspection and self-criticism, you won't easily learn these things. (N2177).

$\mathrm{m}$. The more experienced you are, the more you're able to identify and evaluate the 'noise', and that of course is something I also notice in trainee GPs; they're finding it more difficult, they make less use of the noise than I do. I'm better able to evaluate the importance of the noise and I make better use of it, while they tend to, if they don't understand something they tend to say I don't understand this, so it's probably not important. (M0215).

\section{Personality}

n. You want to reduce the sense of uncertainty, and personally, my criterion is that I have to be able to sleep quietly at night at any rate; I need to feel I've done the right thing. (M0712). In most cases perhaps you don't know exactly what's going on. But you have a general idea, you have a working diagnosis and I personally don't feel bad about it if that involves a certain degree of uncertainty. (V1314).

o. You receive a whole stream of information through a whole range of channels, and you tend to immediately draw your conclusion from that, but you have to force yourself not to do so, in order to stay at the right level of rationality. Because I think it's a real pitfall. (M272).

\section{Consequences of a sense of alarm}

p. Those gut feelings of alarm or reassurance, if there's something that makes me worry, that's a feeling that I feel I want do follow up on. They're alarming signals and I need to check them, I need to make sure for myself whether it's something I really need to act upon or whether I can ignore it because it's nothing serious. (N0819). It raises my state of alertness. I tend to literally sit up and start to focus more. (N0412).

q. Those cases in which I think I have a gut feeling that it's OK, but rational arguments say it's not, I always refer those, on rational arguments, to be on the safe side. And cases where rational arguments say it's OK but my gut feelings say there's something wrong, I also refer, based on my gut feeling. (M0754).

\section{Compass}

r. I had this patient presenting with tightness of the chest, not elicited by exertion, not responding to nitro, nothing in the family history except a younger brother who had some heart complaints at one stage. Apart from that, nothing at all, and yet... He didn't sweat, he seemed very well, and still I had this feeling that I didn't trust the situation. I don't know why... So it turned out he had an inferior wall infarction, and I thought: Yes, I was right! There were no clear indications of an infarction, but I just didn't trust it. And now I won't care if the next four patients I refer turn out to have nothing wrong with them. (M0638)

s. There's a new patient every ten minutes, right, you have to try and understand the problem presented by a patient, you have to ask questions, have the patient undress, do a physical exam, have the patient put on their clothes again, then discuss your findings, explain what you think it is and then make out a prescription and explain about the therapy or try to reassure them before getting ri... err, before getting them to leave, so to say (laughter). And all of that must be done within ten minutes, as you have thirty or thirty-five patients to see that day. So at a certain point you have to, you really need that gut feeling, or you would never get through your surgery, honestly. If you didn't have that gut feeling, you might as well give up tomorrow, I think. This sense of reassurance or alarm, which brings you to your diagnosis, if you haven't got that and always have to rely only on lists and theoretical knowledge, you'd never make it through surgery hour. (H2089). 


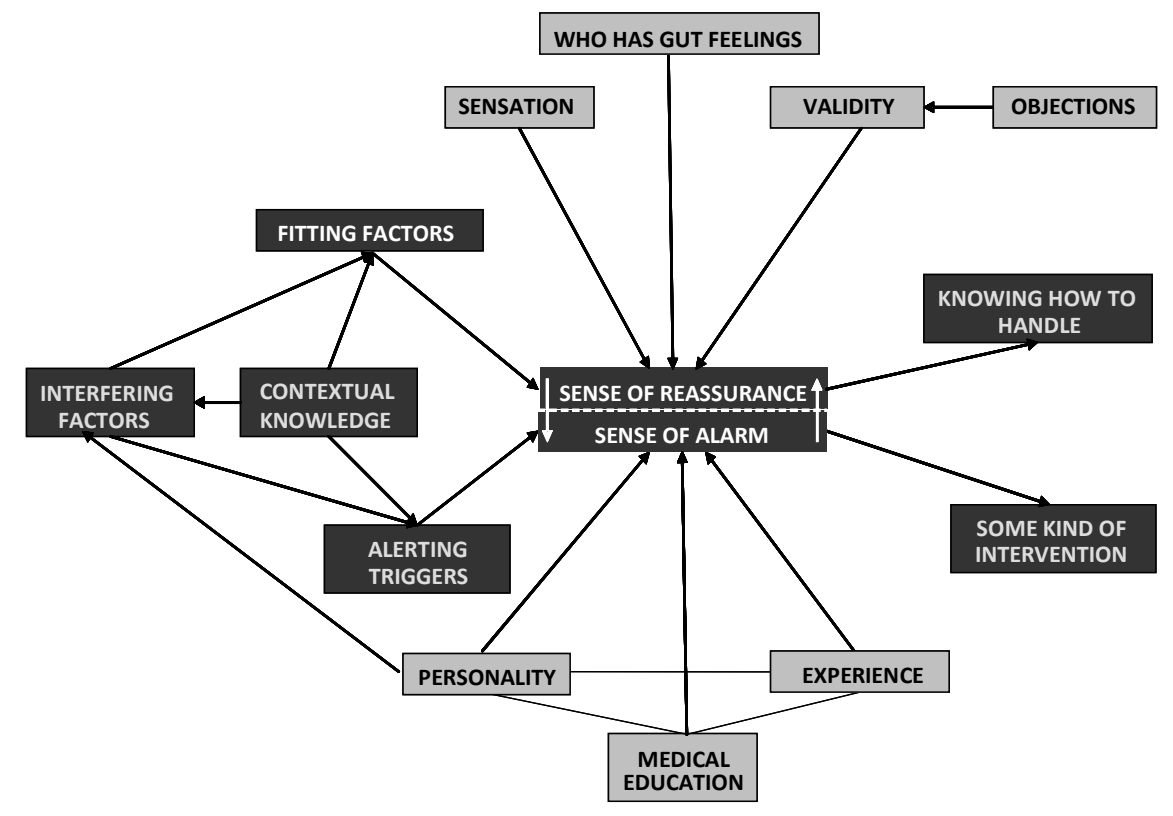

Figure 4.1 Determinants of gut feelings in general practice.

\section{Fitting or alerting factors}

Many GPs used the phrase: it fits or it does not fit in. They explained this as a process of comparing pictures, that is, comparing the current picture which the overall picture they expected based on what they knew about a patient or about a disease (e). In the case of a sense of reassurance, the current picture was compatible with the known pattern for the patient or for the disease. There was congruity. In the case of a sense of alarm, there was a discrepancy between the pictures. Things did not fit in; something was lacking, or just odd, but the GP did not (or not yet) know exactly what (f). The triggers could be found in a patient's presentation, in the way the patient sat or spoke, or in the way other patients of the same age behaved. It was often a very rapid process: GPs realized these things before they even started reasoning.

\section{Contextual knowledge and interfering factors}

Everything a GP knows about a patient in addition to the presented symptoms and signs, i.e. the contextual knowledge, seemed a very important determinant, because it acted as a frame of reference ( $\mathrm{g}$ ). Interfering factors were mentioned as well: emotions like sympathy, aversions and feelings of guilt from the past could interfere 
with gut feelings (h). Sometimes GPs reported that they distrusted their gut feelings or disregarded them because of rational considerations (i).

\section{Medical education and experience}

Most GPs in the focus groups believed that gut feelings can be taught, though they are not easily learned. Medical education teaches students to recognize diseases mainly rationally, by selecting and analyzing symptoms and signs step by step, hypothesizing diagnoses and asking supplementary questions: the hypothetic-deductive method (j). But at the same time there is also a diagnostic feeling, a sense of how a patient tells his story or behaves during the consultation, a sense of what is normal for this patient and what is not. GP trainers in the focus groups said that reflection could be a way to develop diagnostic feelings, including gut feelings (k). GP trainers might ask their trainees to stop counting symptoms and numbers and to start listening to what a patient really means, while observing the patient as well as their own feelings (I). Not every sign or symptom would fit in with a diagnosis and the focus group members said that inexperienced GPs tended to ignore these aberrant and individual elements in the flow of information. After several years of experience, however, they used this knowledge to assess the symptoms and signs presented by patients $(\mathrm{m})$. Experience with patients in general practice contributed to the development of gut feelings and made them reliable. GPs developed their own feeling of what is normal or not and familiarized themselves with prior probabilities in their practice; this then became implicit knowledge. In experienced GPs, the whole process of scanning and comparing pictures had become partly automatic. Before applying any logical reasoning, GPs sometimes knew intuitively whether there was something wrong with a patient or whether it was nothing serious.

\section{Personality}

The ability to tolerate uncertainty and to take some risks seems to influence the way physicians handle gut feelings (n). GPs with less self-confidence might not trust their sense of reassurance. Also, they might fear the opinion of colleagues like hospital specialists, which might make them postpone referral to hospital even if they had a sense of alarm. Rational doctors in our focus groups had difficulty developing gut feelings. Some GPs even regarded gut feelings as a pitfall which they tried to avoid by objective rational diagnostics (o). These GPs pointed out that there is no evidence in the literature for the value of gut feelings.

\section{Consequences of a sense of alarm}

According to the focus group participants, a sense of alarm alerted a physician, and rang an alarm bell. The GP sat up and tried to find objective reasons to support his/her feelings. It thus stimulated the diagnostic process, sometimes resulting in a 
specific diagnosis (p). But in some cases the sense of alarm remained and the GP had to decide whether to take action or use a policy of watchful waiting (q).

\section{Compass}

GPs are often faced with uncertain situations and gut feelings may act as a compass, which is usually active but not always perceptible. Most of the participants trusted this compass in spite of some misjudgments ( $r$ ). It steered them through busy office hours and made complex situations manageable (s).

\section{Discussion}

\section{Main finding}

The findings of our focus group sessions show that gut feelings as a diagnostic instrument play a substantial role in general practice and that many GPs rely on it. The participants distinguished two types of gut feeling, a sense of reassurance and a sense of alarm. In the former case a GP is sure about prognosis and therapy, although he may not always have a clear diagnosis in mind. A sense of alarm means that a GP has the feeling that something is wrong even though objective arguments are lacking. He distrusts the situation and is unsure about prognosis and therapy. He feels some kind of intervention is needed to prevent serious health problems. We identified several determinants: fitting, alerting and interfering factors, sensation, contextual knowledge, medical education, experience and personality. Participants denied that gender played any part in the topic. Instead, a GP's rational and emotional characteristics seems to be more important.

\section{Theory and concept}

Several years ago, Elstein \& Shwarz published a selective review about research into diagnostic reasoning. ${ }^{2}$ They distinguished two main schools of thought on the subject. The first is the psychological approach called problem-solving, with pattern recognition as an important mechanism and illness script and the prototype theory as models for understanding the knowledge structure. ${ }^{3,5}$ The other is the decisionmaking process, based on probability theory, including Bayes theorema and parameters such as predictive value, likelihood ratio and diagnostic panorama. ${ }^{28}$ We have compiled a diagram to visualize this classification and we suggest that gut feelings should be placed near the centre of the diagram because of their different effects (see Figure 4.2: pathways of GPs' diagnostic reasoning). Gut feelings may stimulate diagnostic reasoning, but when this does not lead to a satisfactory diagnosis, action will be taken. Gut feelings may also bypass explicit reasoning, causing a prompt intervention when a GP considers this necessary. Since 
determinants like fitting and alerting factors play key roles, pattern recognition seems an important mechanism to explain the gut feelings that arise $e^{1,2,5,29}$ which is why we have situated gut feelings closer to the problem-solving side in our diagram. However, in contrast to what is claimed in the literature on diagnostic reasoning, the pattern of signs and symptoms does not always fit in and does not give rise to a diagnosis, but to a prognosis and/or intervention. The prognosis is then not a specific prediction of the course of a disease but rather a general feeling that action is required. In the case of a compatible, sticking pattern, GPs feel reassured about the prognosis even if they have as yet no clear diagnosis. We suppose that gut feelings act as a diagnostic instrument that is always active, even though doctors are not always aware of it.

Our description of gut feelings is composed of elements mentioned by the GPs in our focus groups. To ensure that our concept is complete and operational, consensus may have to be achieved by means of a Delphi procedure with experts.

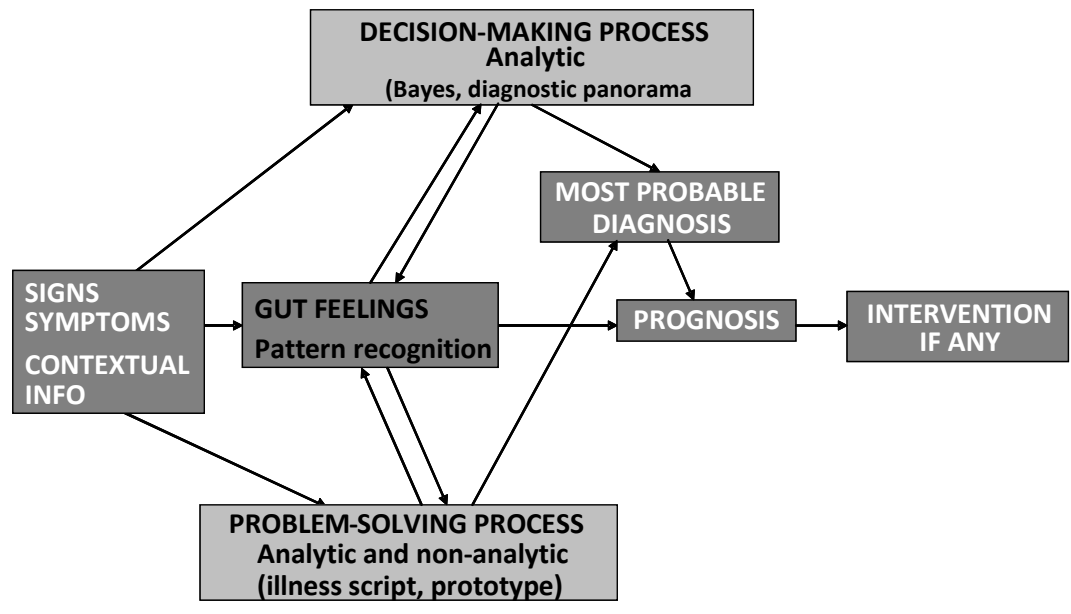

Figure 4.2 Diagnostic reasoning pathways of GPs.

\section{Trustworthiness}

Three independent researchers studied the texts of the focus groups and coded them individually to increase the trustworthiness of the data analysis. Afterwards, it appeared that $90 \%$ of the codes were similar and consensus on disagreements was easily reached. A different group of researchers might have picked slightly different quotations and would probably have coded somewhat differently, but the element of the researchers being part of the process is characteristic of qualitative research analysis, and the possible bias seems small. 


\section{Variation}

Although we now know the essential elements making up the concept of gut feelings, we do not yet know how much they contribute and interact in real practice. GPs vary in the degree to which they rely on gut feelings. Part of this variation may be explained by differences in medical education, while another factor may be the level of experience. How many years of experience in medical practice are necessary to develop and accurately use gut feelings? In our focus groups even GPs with limited experience reported having gut feelings and using them. According to some members of our focus groups, differences in personality play a more important role.

The significance of gut feelings can be affected by the position of GPs within their national healthcare system. In the Netherlands, GPs do not work in hospitals but instead act as gatekeepers. Patients consult their GPs, who weigh the presented signs and symptoms against the background of their contextual knowledge, mostly without X-ray or lab results. ${ }^{30}$ Dutch GPs, like those in several other countries, follow their patients, often over many years, and thus know much about their history and background. ${ }^{31,32}$ It seems interesting to study the significance of gut feelings in other health care systems.

\section{Conclusions}

Most GPs were positive about the significance of gut feelings in general practice and about possibilities to integrate gut feelings in medical education. Although the role of gut feelings in general practice has become much clearer, further research into this complex topic is needed to unravel each determinant's contribution, to examine the accuracy of gut feelings and to make this concept suitable, if possible, for inclusion in medical school curricula. A Delphi consensus procedure may consolidate the elements of the concept of gut feelings and make it operational. We intend to explain gut feelings in the light of current psychological theories and to develop appropriate designs to further study this fascinating phenomenon. 


\section{References}

1. Norman GR, Eva K, Brooks LR, Hamstra S. Expertise in Medicine and Surgery. In The Cambridge Handbook of Expertise and Expert Performance. Edited by Ericsson KA, Charness N, Feltovich PJ, Hoffman RR. New York: Cambridge University Press. 2006:339-54.

2. Elstein AS, Schwarz A. Clinical problem solving and diagnostic decision making: a selective review of the cognitive literature. BMJ 2002;324:729-32.

3. Charlin B, Tardif J, Boshuizen HP. Scripts and medical diagnostic knowledge: theory and applications for clinical reasoning instruction and research. Acad Med 2000;75:182-90.

4. Elstein AS, Shulman L, Sprafka S. Medical Problem Solving: an analysis of clinical reasoning. Cambridge, mass.: Harvard University Press. 1978.

5. Schmidt HG, Norman GR, Boshuizen HP. A cognitive perspective on medical expertise: theory and implication. Acad Med 1990;65:611-21.

6. Hull F. The consultation process. In Decision Making in General Practice. Edited by Sheldon M, Brooke J, Rector A. London: Macmillan. 1985:13-26.

7. Andre M, Borgquist L, Foldevi M, Molstad S. Asking for 'rules of thumb': a way to discover tacit knowledge in general practice. Fam Pract 2002;19:617-22.

8. Boreham NC. The dangerous practice of thinking. Med Educ 1994;28:172-9.

9. Van den Bruel A. The value of signs and symptoms for the diagnosis of serious infections in children in primary care. Catholic University Leuven Belgium. 2006.

10. Buntinx F, Truyen J, Embrechts P, Moreel G, Peeters R. Chest pain: an evaluation of the initial diagnosis made by 25 Flemish general practitioners. Fam Pract 1991;8:121-4.

11. Barraclough K. Medical intuition. BMJ 2006;332(497).

12. Grossman SC, Wheeler K. Predicting patients' deterioration and recovery. Clin Nurs Res 1997;6:45-58.

13. Hams SP. A gut feeling? Intuition and critical care nursing. Intensive Crit Care Nurs 2000;16:310-8.

14. Nordberg M. Just a gut feeling. Emerg Med Serv 1996;25:31,34-40.

15. Pyles SH, Stern PN. Discovery of Nursing Gestalt in critical care nursing: the importance of the Gray Gorilla syndrome. Image J Nurs Sch 1983;15:51-7.

16. Eraut M. Expert and expertise: meanings and perspectives. Learning in Health and Social Care 2005;4: 173-9.

17. Rew L, Barrow EM. State of the science: intuition in nursing, a generation of studying the phenomenon. ANS Adv Nurs Sci 2007;30:E15-E25.

18. Hamm RM Clinical intuition and clinical analysis: Expertise and the Cognitive Continuum. In Professional judgement. A reader in clinical decision making. Edited by Dowie J, Elstein A. Cambridge: Cambridge University Press. 1988:78-104.

19. Dreyfus HL, Dreyfus SE. Mind over machine: The power of human intuition and expertise in the era of the computer. Oxford. 1986.

20. Benner P, Tanner C. Clinical judgment: how expert nurses use intuition. Am J Nurs 1987;87:23-31.

21. Greenhalgh T. Intuition and evidence-uneasy bedfellows? Br J Gen Pract 2002;52:395-400.

22. Pope C, Van Royen P, Baker R. Qualitative methods in research on healthcare quality. Qual Saf Health Care 2002;11:148-52.

23. Vermeire E, Van Royen P, Griffiths F, Coenen S, Peremans L, Hendrickx K. The critical appraisal of focus group research articles. Eur J of Gen Pract 2002;8:104-8.

24. Eva KW. What every teacher needs to know about clinical reasoning. Med Educ 2004;39:98-106.

25. Bowen JL. Educational strategies to promote clinical diagnostic reasoning. N Engl J Med 2006;355: 2217-25.

26. Glaser B, Strauss A. The Discovery of Grounded Theory. Chicago: Aldine. 1967

27. Strauss A, Corbin J: Basics of qualitative research: techniques and procedures for developing grounded theory. London: Sage Publications. 1998.

28. Van Puymbroeck H, Remmen R, Denekens J, Scherpbier A, Bisoffi Z, Van den Ende J. Teaching problem solving and decision making in undergraduate medical education: an instructional strategy. Med Teach 2003;25:547-50.

29. Hani MA, Keller H, Vandenesch J, Sonnichsen AC, Griffiths F, Donner-Banzhoff N. Different from what the textbooks say: how GPs diagnose coronary heart disease. Fam Pract 2007;24:622-7. 
30. Baerheim A. The diagnostic process in general practice: has it a two-phase structure? Fam Pract 2001; 18:243-5.

31. Hjortdahl P. The influence of general practitioners' knowledge about their patients on the clinical decision-making process. Scand J Prim Health Care 1992;10:290-4.

32. Hjortdahl P. Continuity of care. In Oxford Textbook of Primary Medical Care. Volume 1: Principles and Concepts. Edited by Jones R, Britten N, Culpepper L, Gass DA, Grol R, Mant D, Silagy C. Oxford: Oxford University Press. 2004:249-52. 



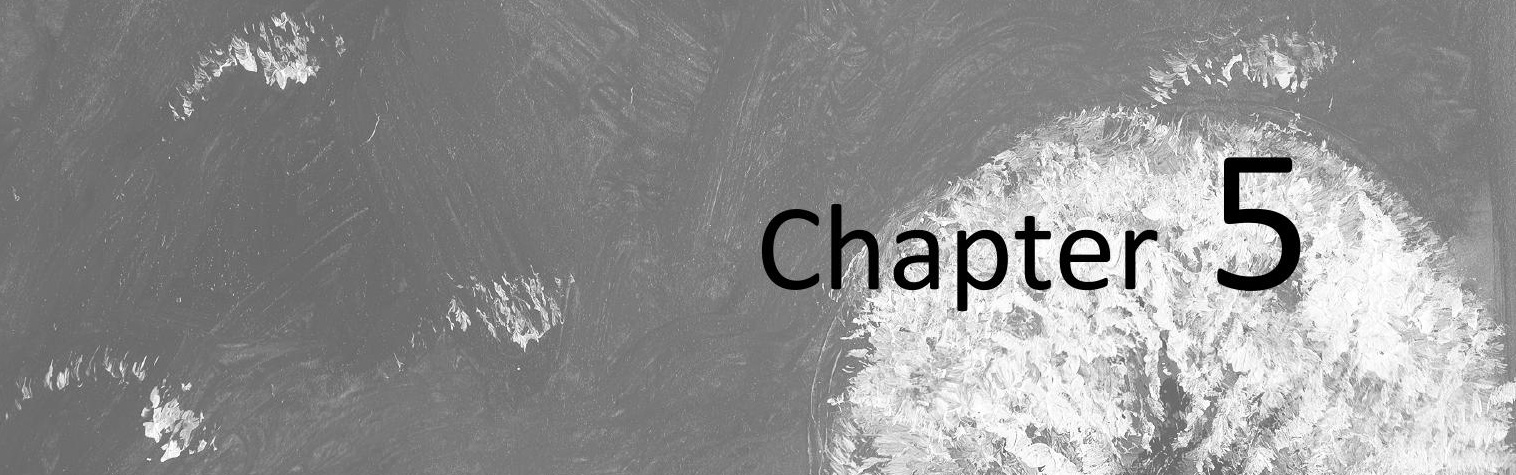

\section{Consensus on gut feelings in general practice}
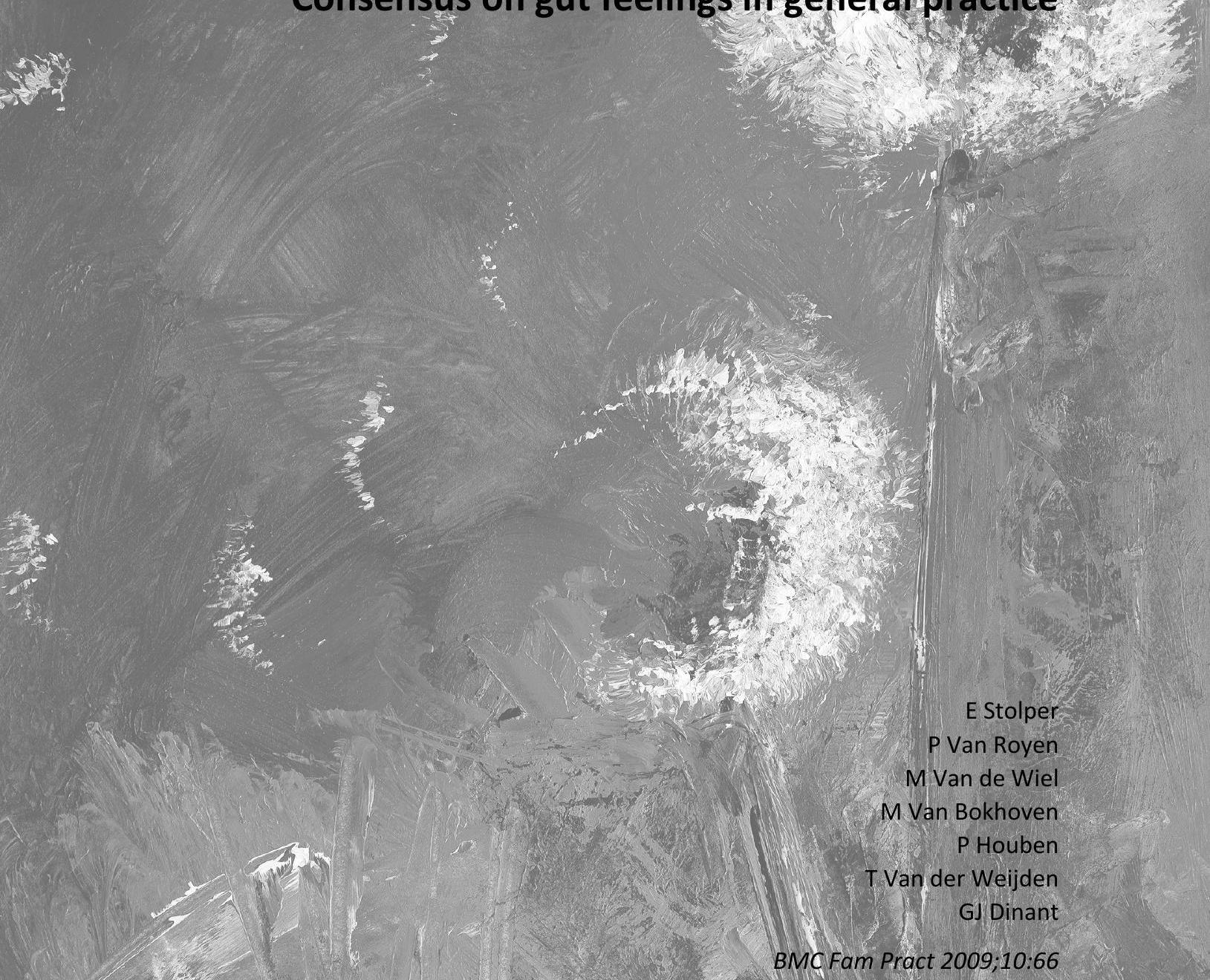

and
aो 


\section{Abstract}

\section{Introduction}

General practitioners (GPs) sometimes base clinical decisions on gut feelings alone, even though there is little evidence of their diagnostic and prognostic value in daily practice. Research to validate the determinants and to assess the test properties of gut feelings requires precise and valid descriptions of gut feelings in general practice which can be used as a reliable measuring instrument. Research question: Can we obtain consensus on descriptions of two types of gut feelings: a sense of alarm and a sense of reassurance?

\section{Methods}

Qualitative research including a Delphi consensus procedure with a heterogeneous sample of 27 Dutch and Belgian GPs or ex-GPs involved in academic educational or research programmes.

\section{Results}

After four rounds, we found $70 \%$ or greater agreement on seven of the eleven proposed statements. A "sense of alarm" is defined as an uneasy feeling perceived by a GP as he/she is concerned about a possible adverse outcome, even though specific indications are lacking: There's something wrong here. This activates the diagnostic process by stimulating the GP to formulate and weigh up working hypotheses that might involve a serious outcome. A "sense of alarm" means that, if possible, the GP needs to initiate specific management to prevent serious health problems. A "sense of reassurance" is defined as a secure feeling perceived by a GP about the further management and course of a patient's problem, even though the doctor may not be certain about the diagnosis: Everything fits in.

\section{Conclusion}

The sense of alarm and the sense of reassurance are well-defined concepts. These descriptions enable us to operationalise the concept of gut feelings in further research. 


\section{Introduction}

Uncertainty and unpredictability are common phenomena in general practice. $^{1}$ Unexplained complaints and ill-defined syndromes together form the group of uncertain diagnoses and uncertainty remains a characteristic part of medical life. ${ }^{2-4}$ Although gut feelings can play a role in dealing with this diagnostic and prognostic uncertainty, ${ }^{5-7}$ studies about the validity of gut feelings are lacking.

A qualitative study using four focus groups of 28 general practitioners (GPs) in the Netherlands distinguished two types of gut feelings: a sense of alarm and a sense of reassurance. ${ }^{8}$ Gut feelings are based on the recognition of a pattern that agrees or disagrees with the expected pattern for an individual patient or for a clinical picture, sometimes without a specific diagnosis. Although GPs are not always aware of their sense of reassurance, a sense of alarm alerts GPs and starts or re-starts the process of diagnostic reasoning: something does not fit in. This sense of alarm makes a GP feel uneasy and restless until the reason has been found. Sometimes there is a lack of objective arguments and the sense of unease remains. Three elements are important in defining a sense of alarm: the feeling that there seems to be something wrong without the doctor having objective arguments, a distrust of the situation because of uncertainty about the prognosis of the complaints, and the need for some kind of intervention to prevent serious health problems. When GPs experience a sense of reassurance, they are sure about the prognosis and therapy, even in the absence of a diagnosis. Gut feelings thus act as a compass in situations of uncertainty. To follow-up on the four focus groups and to operationalise this concept in further research and educational programmes, we organized a consensus procedure among opinion leaders and experts in general practice to explore if sufficient agreement could be reached on precise and valid descriptions of both types of gut feeling.

\section{Methods}

A modified Delphi consensus procedure was used combining several convential postal rounds and one face-to-face group session (see Figure 5.1). The aim of such a procedure, named after the famous Delphic oracle, is to determine the extent to which experts agree about a given issue. ${ }^{9,10}$ This anonymous process was organised via a series of structured documents, including a number of statements, sent by post or e-mail to all participants, inviting them to rate their agreement on a scale from 1 (total disagreement) to 9 (total agreement). We encouraged the participants to explain their ratings, at least in the case of a rating lower than 7 , by adding comments on the statements. Afterwards, these ratings and comments were used by two researchers (ES, PVR) to adjust the statements. After each round, the ratings and comments were used by two researchers (ES, PVR) to accept a statement or to adjust or reject the statements (if there was less than $70 \%$ agreement with a rating of 7 or 
higher). This phase of the Delphi technique involved an important qualitative component of considering, deliberating, weighing arguments and comments, thinking it over and finally deciding together (ES, PVR) to change a statement using different wording, another phrase or more fitting expression. However, the participants' rating afterwards played a decisive role in assessing whether an adaptation was an improvement or not. This whole process was checked by the co-authors. After each round, the ratings and comments were summarised and incorporated in a new version of the document. The participants then re-rated their agreement with each statement, with the possibility to change their rating in view of the group's response. The rounds were repeated till consensus was reached or seemed impossible. Not until the fourth round were the participants informed about the results of our previous focus group study into gut feelings in order to prevent any bias by this information. The fourth round involved three meetings with 5-7 participants each, where they discussed the adjusted statements in group and rated them individually for the last time without giving written comments. The nine absent participants rated the statements afterwards by e-mail. Consensus in favour of a statement was defined as $70 \%$ or more agreement with a rating of 7 or higher.

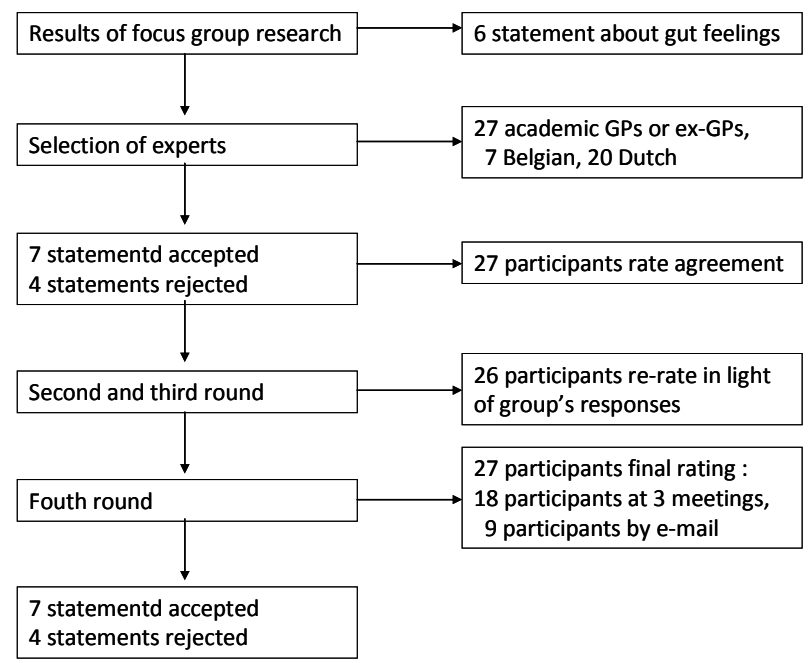

Figure 5.1 Flowchart Delphi consensus procedure about gut feelings.

We started with six statements, which were selected by the project group (i.e. the authors) and were based on the results of our previous focus-group study (see Text box 5.1). Next, we purposively sampled well-known opinion leaders and experts in general practice in the Netherlands and Belgium, who were working at universities in 
educational or research programmes, since the consensus statements had to be suitable for educational and research studies on the topic. We approached 30 colleagues by phone, 27 of whom accepted our invitation and received written information about the procedure. Because no patients were involved and GPs were only asked about their opinion and perception, no ethical permission was required. During the Delphi-procedure, all statements and comments were formulated in Dutch; afterwards all statements were translated into English and back-translated, in order to check for the right wording.

Text box 5.1 Statements submitted to Delphi participants.

- Statement 1: A GP's 'sense of reassurance or alarm' is mostly related to their degree of certainty about the prognosis of the complaints.

- Statement 2: The 'sense of reassurance or alarm' has very little to do with formulating working hypotheses or establishing diagnoses.

- Statement 3: A 'sense of alarm' implies that a GP is worried about a patient's health status, even though he or she has as yet no objective argument for this; it is a sense of 'there's something wrong here'.

- Statement 4: A 'sense of alarm' means that some form of intervention seems necessary to prevent imminent serious health problems.

- Statement 5: A 'sense of reassurance' means that a GP feels secure about the prognosis, even though there are no objective arguments for this: everything fits in.

- Statement 6: A 'sense of reassurance' implies that a GP feels secure about whether and what therapy needs to be started.

\section{Results}

Four rounds were needed to reach consensus. During the entire process, eleven statements were presented to the participants, the six original ones and five new ones that emerged from the comments. Seven statements were accepted and four rejected (see Text box 5.2 and 5.3). There was a high level of response, and a large number of comments were given per round (see Table 5.1). In the first round, the participants were invited to add their own statements about gut feelings. Two supplementary statements were then incorporated in the next three rounds (statements 7 and 8). One statement was a comprehensive definition of gut feelings, while the other expressed the dynamic character of gut feelings. However, it proved to be impossible to get sufficient agreement about one definition that included all aspects of both types of gut feeling, despite several adjustments. 
Text box $5.2 \quad$ Accepted statements.

- Statement 1a: A 'sense of alarm' means that a GP perceives an uneasy feeling as he/she is concerned about a possible adverse outcome.

- Statement 3: A 'sense of alarm' implies that a GP worries about a patient's health status, even though he/she has found no specific indications yet; it is a sense of 'there's something wrong here'.

- Statement 2: A 'sense of alarm' activates the diagnostic process by stimulating a GP to formulate and weigh up working hypotheses that might involve a serious outcome.

- Statement 4: A 'sense of alarm' means that, if possible, the GP needs to initiate specific management to prevent serious health problems

- Statement 9: A 'sense of alarm' will decrease as the diagnosis and the right management become clearer.

- Statement 5: A 'sense of reassurance' means that a GP feels secure about the further management and course of a patient's problem, even though he/she may not be certain about the diagnosis: everything fits in.

- Statement 8: The 'sense of reassurance' and the 'sense of alarm' constitute a dynamic element in a GP's diagnostic process.

Text box $5.3 \quad$ Rejected statements.

- Statement 1: A GP's 'sense of reassurance or alarm' is mostly related to their degree of certainty about the prognosis of the complaints.

- Statement 1b: A 'sense of reassurance' means that a GP feels at ease as he or she is confident about the further approach and outcome.

- Statement 6: A 'sense of reassurance' implies that a GP has a clear idea whether a particular therapy would be useful and needs to be started.

- Statement 7: A 'sense of alarm' is a sensation/feeling that a doctor is unable to express in specific terms and that is prompted by data from medical history-taking and / or examination of a patient. It helps the doctor in taking further diagnostic and therapeutic decisions in order to prevent a potentially serious outcome for the patient.

Table 5.1 Number of comments (n), consensus (\%) per round and final result in terms of agreement or disagreement with the proposed statements.

\begin{tabular}{|l|c|c|c|c|c|c|c|c|c|}
\hline Statement & \multicolumn{2}{|c|}{ Round 1 } & \multicolumn{2}{|c|}{ Round 2 } & Round 3 & Round 4 & Result & In round \\
\hline & $\mathrm{n}$ & $\%$ & $\mathrm{n}$ & $\%$ & $\mathrm{n}$ & $\%$ & $\%$ & & \\
\hline 1 & 26 & 37 & & & & & & Rejected & 1 \\
\hline $1 \mathrm{a}$ & & & 18 & 76 & 4 & 100 & & Accepted & 3 \\
\hline $1 \mathrm{~b}$ & & & 16 & 69 & & & & Rejected & 2 \\
\hline 2 & 26 & 33 & 12 & 73 & 9 & 76 & 89 & Accepted & 4 \\
\hline 3 & 19 & 59 & 10 & 92 & 3 & 100 & & Accepted & 3 \\
\hline 4 & 22 & 59 & 17 & 58 & 17 & 58 & 89 & Accepted & 4 \\
\hline 5 & 19 & 44 & 12 & 92 & 8 & 88 & 85 & Accepted & 4 \\
\hline 6 & 20 & 33 & 14 & 77 & 10 & 62 & & Rejected & 3 \\
\hline 7 & & & 24 & 33 & 18 & 42 & & Rejected & 3 \\
\hline 8 & & & 19 & 31 & 19 & 39 & 74 & Accepted & 4 \\
\hline 9 & & & 18 & 50 & 11 & 77 & 78 & Accepted & 4 \\
\hline
\end{tabular}


Although uncertainty emerged as a key word from the focus groups, it was difficult to keep it in, due to disagreement about the first statement presented to the Delphi panel. In this statement we had tried to unify the two types of gut feeling in one phrase about the degree of uncertainty. Although the significance of uncertainty as a central element in the concept of gut feelings had resulted from our previous research, it seemed too theoretical to be used to summarise the two types of gut feeling in one statement in the first round. Therefore, we split up the first statement (into $1 \mathrm{a}$ and $1 \mathrm{~b}$ ) in the second round and offered all statements relating to the sense of alarm separately from those relating to the sense of reassurance. Although some GPs commented in the last round that they would have preferred the notion of uncertainty to be included, it is still implied in statements 1 a and 3 as "uneasy feeling", "worries" and "there is something wrong here" and in statement 5 as "secure feeling" and "uncertain about the diagnosis" (see Text box 5.2).

In the second round we added another statement (9) about the process of gut feelings, based on the comments of the participants. Statement 6 was accepted in round 2, but further explanation, intended to reach a higher degree of consensus, confused the participants and we therefore withdrew this statement. Furthermore, statement 5 already comprised all elements of the sense of reassurance.

In the course of this Delphi procedure, the statements gradually became more focused. After three rounds, we had already reached sufficient consensus about several statements, but the consensus even increased after the wording was further adjusted. In the end, it was not difficult to distinguish between accepted and rejected statements.

\section{Discussion}

We reached consensus on a broadly based and precise description of the two types of gut feeling: a sense of alarm and a sense of reassurance. The key elements in the results of our earlier focus group study were confirmed and transformed into clear, practical descriptions that could be used by doctors participating in general practice research. A sense of alarm is defined as an uneasy feeling perceived by a GP as he/she is concerned about a possible adverse outcome, even though specific indications are lacking: There's something wrong here. This activates the diagnostic process by stimulating the GP to formulate and weigh up working hypotheses that might involve a serious outcome. A sense of alarm means that, if possible, the GP initiates specific management to prevent serious health problems. A sense of reassurance is defined as a secure feeling perceived by a GP about the further management and course of a patient's problem, even though he/she may not be certain about the diagnosis: Everything fits in.

We distinguished four interrelated dimensions in the accepted statements: the meanings of the sense of alarm and the sense or reassurance (statements 1a, 3 and 
$5)$, the vague and uneasy prognostic feeling lacking clear causes (statements 1a and 3) and the consequences of the sense of alarm (statements 2 and 4). And the statements 8 and 9 express that this is not a steady state: a sense of alarm is sometimes replaced by a sense of reassurance during the encounter and vice versa.

The two types of gut feelings are not each other's mirror images. The essential element of the sense of alarm is the lack of a diagnosis whereas a clear diagnosis can reassure a GP, even though it may actually be an unfavourable diagnosis for the patient.

Several participants associated gut feelings with feelings of empathy towards the patient but the topic of our research was the significance of GPs' gut feelings in the diagnostic process, rather than the GPs' empathy, which has no diagnostic value. Empathy comes into play after the diagnosis has been established, for instance in the case of an unfavourable diagnosis, when the doctor has to initiate treatment and/or define a management plan, whereas the gut feelings we wish to study are used in the diagnostic process itself. In the second round, the participants were therefore asked to use this basic assumption as a starting point. Several colleagues expressed their disagreement with this decision in their ratings.

The Delphi consensus technique has been used widely in health care research ${ }^{9,10}$ and its validity and trustworthiness have been the topic of many debates. However, we followed the guidelines for the use of this consensus technique ${ }^{11}$ and the transparency of the way we dealt with the comments and ratings and how we adjusted or rejected statements may have improved the validity and reliability of the consensus achieved. Although this Delphi consensus procedure only included 27 participants, they were all well-known experts from eight universities in two countries with wide experience both as GPs and researchers or medical educators. Their representativeness for general practice and their power to implement the findings may contribute to the generalizability of the results. Furthermore, the consensus is in line with the focus group results. The procedure started with statements based on our earlier focus group research, without the participants being aware of this. The validity of the focus group results was checked by comparing it with the results achieved by the consensus procedure, a process commonly referred to as triangulation. ${ }^{12,13}$ Compared with the results of the focus groups, the descriptions of both types of gut feeling have now been improved and have become more precise and complete than before.

Another possible weakness of our study is what is known as regression to the mean: participants are inclined to adjust their opinions during the process of finding consensus. ${ }^{14}$ Nevertheless, the degree of agreement reached about seven statements was high and four statements were not accepted despite several adjustments. 


\section{Conclusions}

We conclude that the sense of alarm and the sense of reassurance are well-defined concepts and the descriptions resulting from the Delphi procedure enable us to operationalise the concept of gut feelings in further research into the validity of this "compass" as well as educational programmes. 


\section{References}

1. Innes AD, Campion PD, Griffiths FE. Complex consultations and the 'edge of chaos'. Br J Gen Pract 2005;55:47-52

2. Dinant GJ. Diagnosis and decision. Undifferentiated illness and uncertainty in diagnosis and management. In: Jones R, Britten N, Gulpepper L, Gass D, Grol R, Mant D, Silagy C, editors. Oxford Textbook of Primary Medical Care.Oxford: Oxford University Press. 2004:201-3.

3. Griffiths F, Green E, Tsouroufli M. The nature of medical evidence and its inherent uncertainty for the clinical consultation: qualitative study. BMJ 2005;330:511.

4. Tanenbaum SJ. Uncertainty, consultation, and the context of medical care. BMJ 2005;330:515.

5. Barraclough K. Medical intuition. BMJ 2006;332(497).

6. Van den Bruel A. The value of signs and symptoms for the diagnosis of serious infections in children in primary care. Catholic University Leuven Belgium;.2006.

7. Buntinx F, Truyen J, Embrechts P, Moreel G, Peeters R. Chest pain: an evaluation of the initial diagnosis made by 25 Flemish general practitioners. Fam Pract 1991;8:121-4.

8. Stolper CF, Van Bokhoven MA, Houben PHH, Van Royen P, Van de Wiel M, Van der Weijden T, Dinant GJ. The diagnostic role of gut feelings in general practice. A focus group study of the concept and its determinants. BMC Fam Pract 2009;10:17.

9. Jones J, Hunter D. Consensus methods for medical and health services research. BMJ 1995;311: 376-80.

10. Hasson F, Keeney S, McKenna H. Research guidelines for the Delphi survey technique. J Adv Nurs 2000;32:1008-15.

11. Fink A, Kosecoff J, Chassin M, Brook RH. Consensus methods: characteristics and guidelines for use. Am J Public Health 1984;74:979-83.

12. Denzin N.K. The research act. 3rd ed. New York: Prentince Hall. 1989.

13. Kimchi J, Polivka B, Stevenson JS. Triangulation: operational definitions. Nurs Res 1991;40:364-6.

14. Woudenberg F. An evaluation of Delphi. Technological Forecasting and Social Change 1991;40:131-50. 

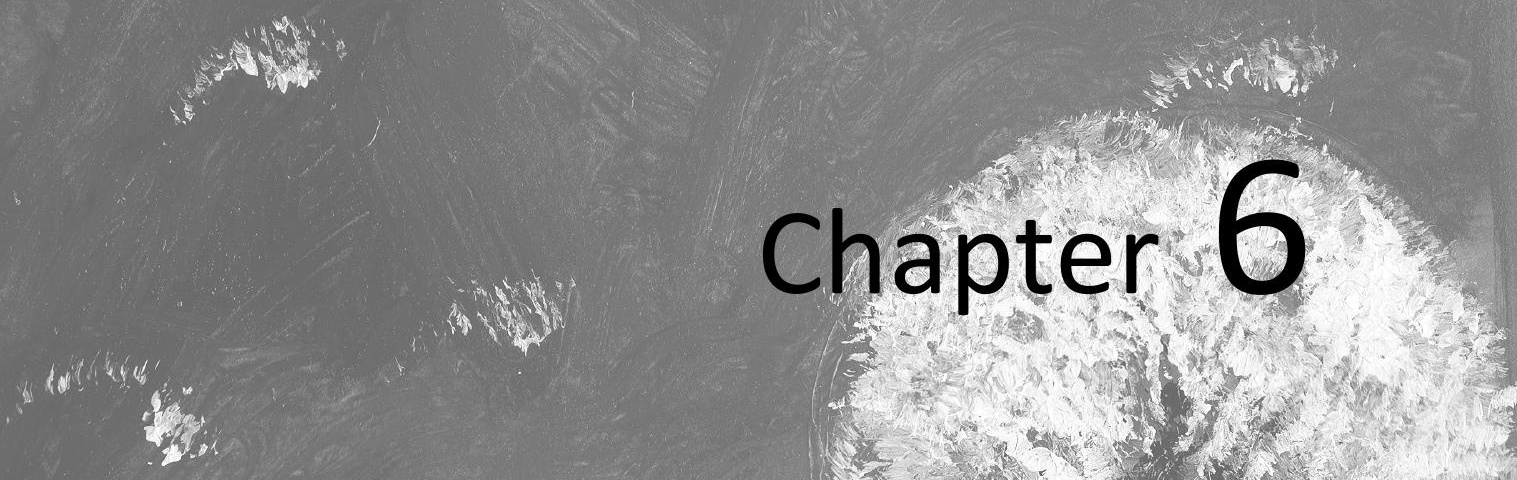

How do disciplinary tribunals evaluate gut feelings

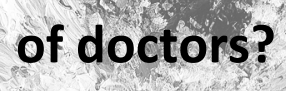

An analysis of Dutch tribunal decisions 2000-2008

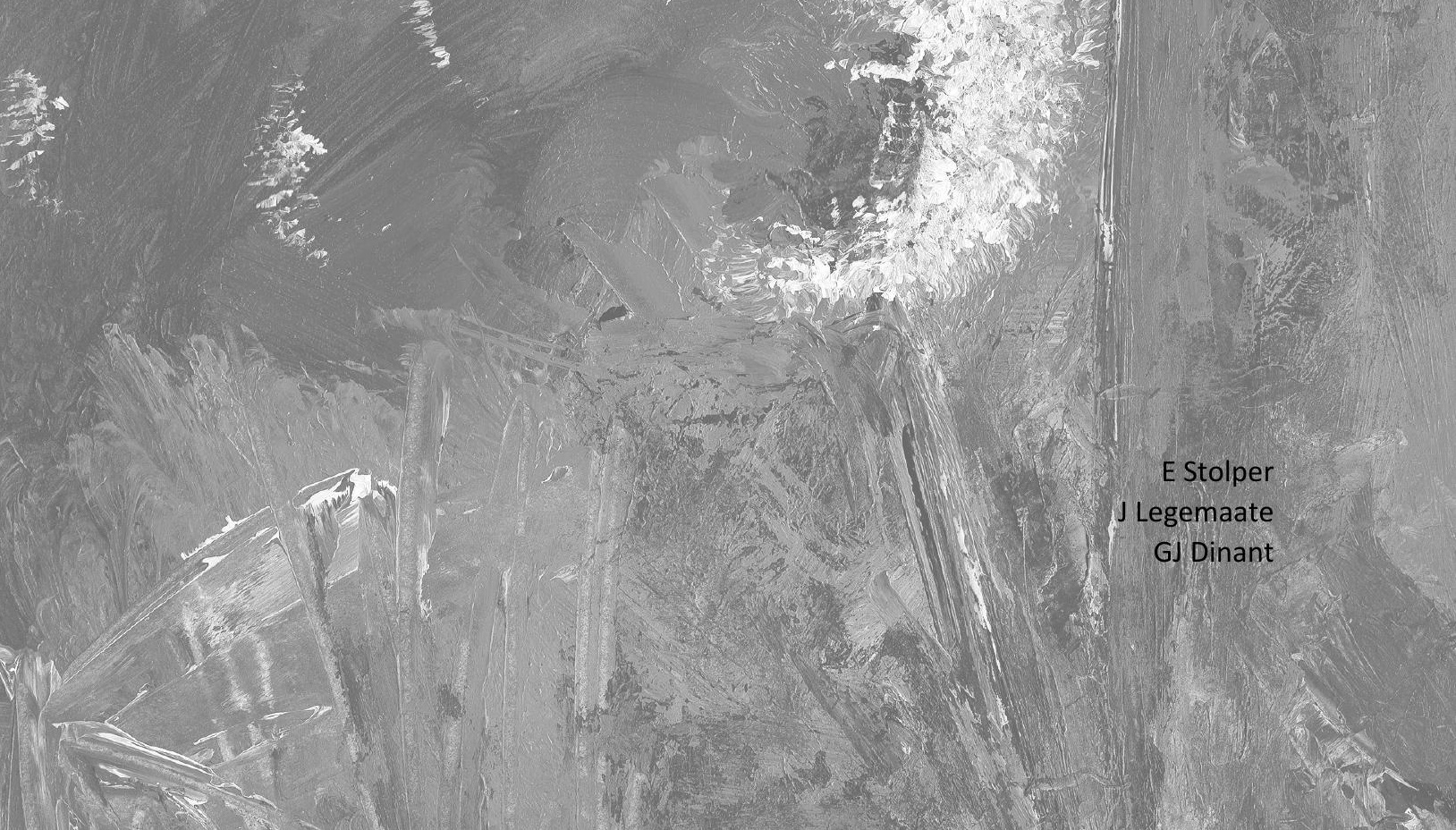




\section{Abstract}

\section{Introduction}

A sense of alarm, which is a form of gut feeling, sometimes plays a part in published decisions of medical disciplinary tribunals in the Netherlands. Since the judgements of these tribunals are regarded as setting standards for professional attitudes and interventions in the Netherlands, the question arises how disciplinary tribunals have evaluated gut feelings in their judgements. Furthermore, we wanted to compare how disciplinary tribunals in other European countries deal with gut feelings in diagnostic reasoning.

\section{Methods}

An exploratory study was performed by searching two Dutch digital databases over a nine-year period and asking 26 national representatives and key persons of the European General Practice Research Network for information about the role of gut feelings in the decisions of disciplinary tribunals in their countries.

\section{Results}

A sense of alarm was mentioned in judgements in 34 Dutch cases. The final outcome in these cases was often a serious threat or damage to the patient's somatic health. Defendants were hardly ever reproached for missing the correct diagnosis, but mostly for not acting in a professional manner. The sense of alarm was referred to as a diagnostic tool to assess a patient's situation, although the judgements indicate that it must be followed by further diagnostic steps in agreement with professional standards. The role of gut feelings in decisions of disciplinary tribunals in Europe is unclear.

\section{Discussion}

The overrepresentation of general practitioners (GPs) in our study - two-thirds of all decisions we studied involved GPs - can be explained by their frontline position in the Dutch national health care system. We conclude that the sense of alarm as a diagnostic tool has been taken seriously by Dutch disciplinary tribunals. The timely development of a sense of alarm is considered to be an element of the professional standards for doctors, though it must be followed by extensive history-taking, physical examination and careful documentation. 


\section{Introduction}

In 2005, a Dutch General Practitioner (GP) was disciplined by a medical disciplinary tribunal for not having had a timely sense of alarm when seeing a patient with severe headache. When the GP finally got, as he called it, the gut feeling that there was something wrong, he postponed his decision to consult a neurologist and instead phoned a colleague the day after. His patient turned out to have a severe subarachnoidal bleeding. The regional medical disciplinary tribunal (referred to below as the tribunal) disciplined the GP because he had not acted as might have been expected according to professional guidelines. (RT Eindhoven, 11-08-2005, GJ 2005, 115, http://www.tuchtcollege-gezondheidszorg.nl/uitspraken) In 2004, a cardiologist was disciplined for failing to recognize that his patient's situation necessitated an emergency echocardiography. In the tribunal's opinion, the facts of the case should have induced a sense of alarm during the consultation. (CTG 06-01-04, 2002/053, http://www.tuchtcollege-gezondheidszorg.nl/uitspraken) In 2008, a tribunal rejected a complaint filed against a GP by the parents of an ill baby. During the consultation, they had told the GP about their gut feeling that there was something wrong with their child, but the GP did not find any alarming signs at the time. Afterwards, however, the baby turned out to have meningitis. (RT Zwolle, 22-5-2008, 146/2007, http://www.tuchtcollege-gezondheidszorg.nl/uitspraken)

Apparently, then, disciplinary tribunals sometimes take into account gut feelings in their considerations when they pass judgement on physicians against whom a complaint has been filed. Since the judgements of these tribunals are regarded as setting standards for professional attitudes and interventions in the Netherlands, it is important to study how disciplinary tribunals have evaluated gut feelings in their judgements.

In the Netherlands and Flanders, many GPs use a Dutch phrase ("niet-pluis") to express a sense of alarm, that is the gut feeling that something does not fit in or seems wrong. ${ }^{1,2}$ In fact, GPs all over Europe as well as some hospital-based specialists recognize such a sense of alarm, although they do not always have a specific expression for it. ${ }^{3-6}$ Research in general practice has identified two types of gut feelings: a sense of alarm and a sense of reassurance. The sense of alarm - the Dutch "niet-pluis" - means that a GP worries about a patient's health status, even though they have found no specific indications yet; it is the feeling that "there's something wrong here". It means that the GP needs to initiate specific management to prevent serious health problems. The sense of reassurance -the Dutch "pluis" - means that a GP feels secure about the further management and course of a patient's problem, even though they may not be certain about the diagnosis: "everything fits in". Such gut feelings play a substantial diagnostic role in general practice ${ }^{7-9}$ and can be regarded as a third track in GPs' diagnostic reasoning next to medical problem-solving and medical decision-making. These three diagnostic tracks are integrated by the interacting analytical and non-analytical cognitive processes. GPs are often faced with 
uncertain situations and gut feelings may act as a compass, which is usually active but not always perceptible. Focus group research has revealed that most GPs trust this compass in spite of some misjudgements. ${ }^{1}$ It steers them through busy office hours and makes complex situations manageable. Some GPs distrust their gut feelings, ${ }^{1}$ and although the value of this diagnostic instrument has been clarified, further research into the validity of gut feelings in general practice is needed.

We studied the way disciplinary tribunals in the Netherlands have used gut feelings in their considerations and what this means for the professional standards on the quality of health care. We compared this with the way disciplinary tribunals in other European countries have dealt with gut feelings in their judgements.

\section{Methods}

First, we explain how the disciplinary tribunals in Dutch health care are organized and how complaints against physicians or other health professionals are dealt with. This information is needed as background knowledge to evaluate the results of our study. Next, an exploratory study was performed by searching an extensive digital database of tribunals judgements (http://www.tuchtcollege-gezondheidszorg.nl/uitspraken). We selected those cases heard by Dutch disciplinary tribunals over a nine-year period (2000-2008) in which gut feelings played a part using the search term "niet-pluis". A similar search was undertaken in a Dutch professional journal (Medisch Contact) which sometimes reports on striking and instructive decisions of Dutch disciplinary tribunals. Subsequently, 26 national representatives and key persons of the European General Practice Research Network (EGPRN) were asked to provide information about the role of gut feelings in decisions of disciplinary tribunals in their countries, by searching medical tribunal databases, if possible.

Relevant characteristics of tribunal decisions referring to sense of alarm were then summarized. We listed descriptive phrases referring to the sense of alarm, the consequences they should have according to the tribunals' considerations and the tribunals' evaluations in cases where a sense of alarm had been lacking.

\section{Results}

\section{How are Dutch disciplinary tribunals organized?}

The Dutch Individual Health Care Professions Act empowers regional disciplinary tribunals to deal with complaints about the professional conduct of physicians, nurses, midwives, psychotherapists, health care psychologists, physiotherapists, dentists and pharmacists. Complaints can be filed by patients, their family members, or the Health Care Inspectorate. Each year, approximately 1300 complaints are filed against 
professionals from these groups (http://www.tuchtcollege-ezondheidszorg.nl/Images/ Jaarverslag\%202008_tcm37-29660.pdf). Each of the five regional tribunals (RTs), often referred to as "medical courts", consists of five members: two lawyers and three persons from the same profession as the defendant. Appeals in all cases are judged by the Central Disciplinary Tribunal (CTG) in The Hague, consisting of three lawyers and two persons from the same profession as the defendant. The main objective of the tribunals is to safeguard and improve the quality of care, while a secondary objective is to provide patients with an opportunity to complain and seek redress.

Complaints are dealt with according to a procedure prescribed by law. Both parties are given the opportunity to express their views in writing, after which a formal session takes place during which the tribunal can ask questions and the complainant and the defendant can once more communicate their viewpoints. The tribunal then passes judgement after a number of weeks. This whole process (from filing the complaint to the tribunal passing judgement) usually takes more than a year. If a complaint is judged to be founded, a variety of disciplinary measures can be imposed, ranging from a warning or a reprimand to a fine or even temporary or permanent suspension, though the heavier sanctions are rarely imposed. In the case of a "first offender" who acted in good faith but failed to comply with professional standards, the tribunals tend to give a warning or a reprimand. The decisions of the disciplinary tribunals are published on a website (http://www.tuchtcollege-gezondheidszorg.nl) and a selection are also published in the various periodicals of the professional organizations involved, and in legal journals. The publication of decisions is an important means to achieve the aforementioned objective of improving the quality of care. Health professionals are expected to take note of decisions relevant to their domain and apply them in their own practice.

\section{Cases involving gut feelings}

Our search yielded 34 cases where the expression "niet-pluis" (sense of alarm) was used in the judgements on 23 GPs (68\%), 8 specialists (24\%), 2 midwives and 1 nurse practitioner. (See Table 6.1) It was mostly found in the defendant's response to the complaints, the RTs' considerations and the evaluations by the CTG. Sometimes it was first used in the defendants' responses but quite often it appeared only in considerations or evaluations. In all 34 cases, the sense of alarm concept was used in line with our description, and always in situations of diagnostic uncertainty or failures. The expression "pluis" (sense of reassurance) was never used. In nearly all cases, the final outcome was a serious threat or damage to the patient's somatic health, resulting in death in 10 cases (29\%). In 19 cases, the final judgement was a disciplinary measure (56\%), seven of which concerned cases involving the patient's death $(37 \%$ of the disciplinary measures). Defendants were hardly ever reproached for missing the correct diagnosis, but mostly for not acting as might have been expected on the basis of the prevailing professional standards. 


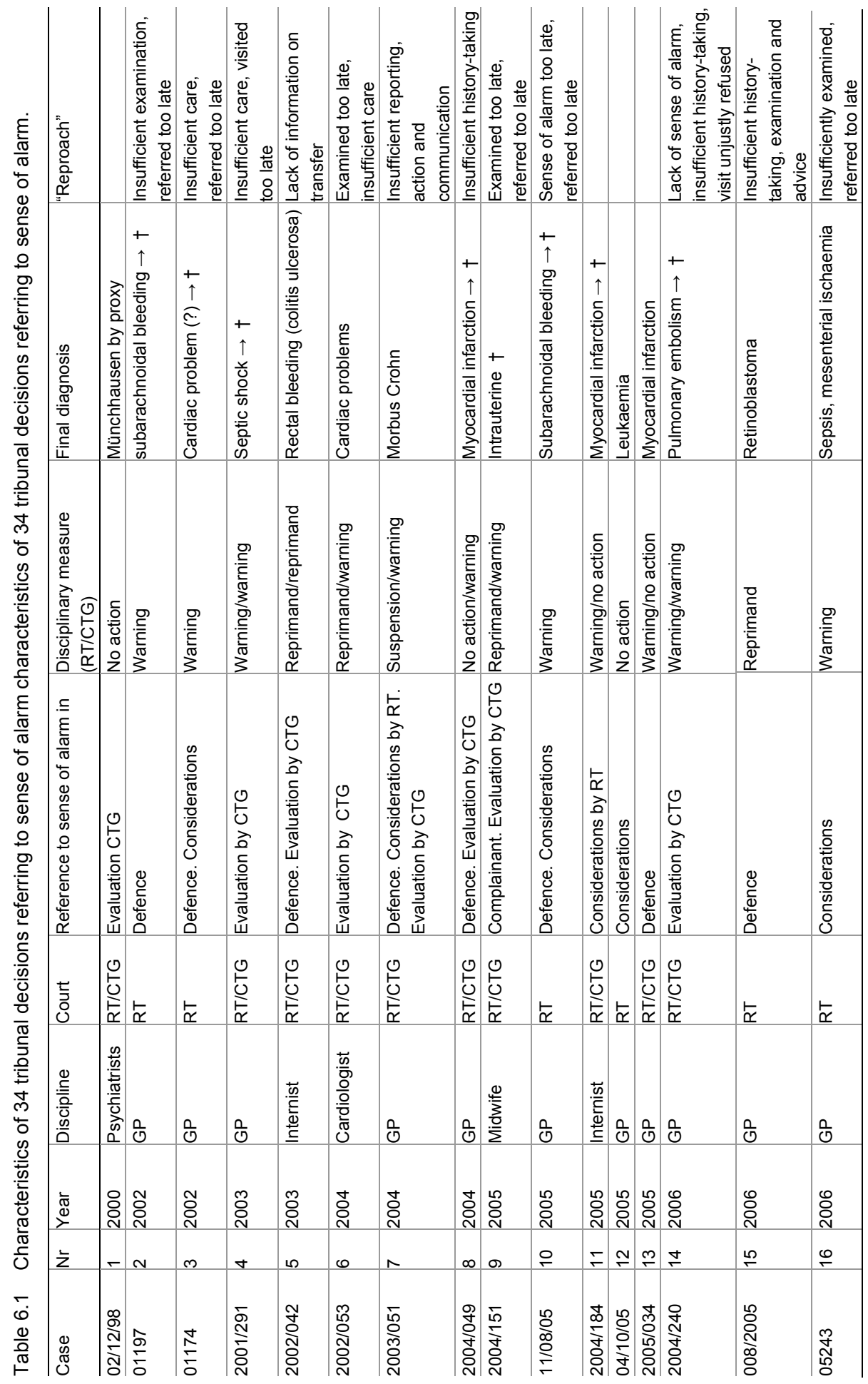




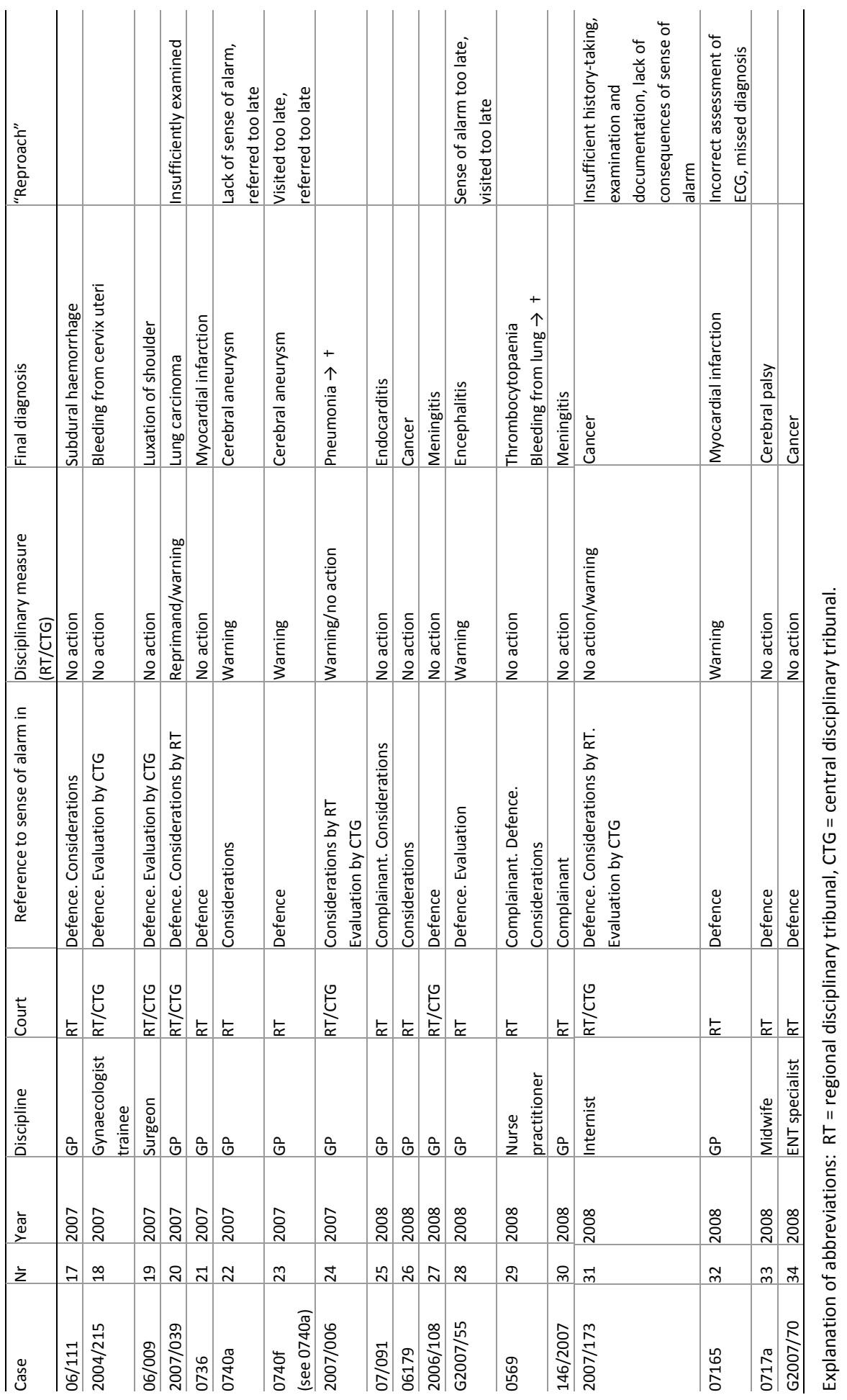


The sense of alarm seems to be a well-known concept for physicians and medical courts, as only one published verdict included a description, describing it as an alarm bell going off. (See Text box 6.1, Descriptive phrases) It is referred to as a diagnostic tool used to assess a patient's situation, although the judgements indicate that it must be followed by further diagnostic steps in agreement with professional standards, like extensive history-taking and physical examination, in order to further clarify the patient's situation. (See Text box 6.1, Consequences) A sense of alarm has to be objectified, and if necessary must result in a more careful management, e.g. documenting all important information and handing it over to colleagues if referred, consulting experienced colleagues or referring the patient to a specialist or hospital. In cases involving children, the parent's sense of alarm must be taken seriously. Sometimes, tribunals have reproached physicians for not having had a sense of alarm, while there were clear indications in the case history, as well as at the time the patient was evaluated. (See Text box 6.1, Unjustified lack of sense of alarm)

Text box 6.1 Judgements.

\section{Descriptive phrases referring to sense of alarm}

- In the RT's opinion, the circumstances should have set alarm bells ringing, or have resulted in a sense of alarm in the trainee doctor. (Case No. 24)

\section{Consequences of sense of alarm}

- The defendant's initial sense of alarm subsided as exam findings gave no clear indications of cardiac problems. Although the correct diagnosis of cardiac problems was missed, the history-taking and physical exam were appropriate and the defendant's actions were not incompatible with his duty of care. (No. 21)

- In the tribunal's opinion, the pattern of complaints in this case, which raised a sense of alarm in the defendant, should induce a doctor to ensure that the patient was examined further. (No. 3)

- The doctor's initial sense of alarm disappeared as the patient's chest pain ... proved to be tenderness. In this sense, the doctor was clearly misled by the symptoms. Nevertheless, the clues from the patient's history ... should have induced the doctor to ask further questions. (No. 8)

- The doctor's initial sense of alarm subsided because the ECG showed no evident signs of infarction. Considerations: ECG was incorrectly evaluated and this evidence was given too much weight. Triage, history and examination should have led the doctor to formulate a presumptive diagnosis of cardiac infarction. (No. 32)

- RT: the doctor should have objectified his sense of alarm and should have given appropriate instructions. CTG: the doctor's actions were correct. (No.11)

- The trainee gynaecologist experienced a sense of alarm, and therefore referred the patient to her supervisor. (No. 18)

- The doctor had a sense of alarm even though he saw no abnormal signs on the X-ray. He therefore ordered further $\mathrm{X}$-rays and referred the patient to a more experienced colleague. This means that he acted correctly, although he had missed the visible luxation. (No. 19)

- The defendant stated ... that he did experience a sense of alarm... The defendant did not pursue this sense of alarm. (No. 7)

- The defendant was unable to establish a definitive diagnosis but only had a sense of alarm ... which induced her to refer the young patient. (No. 12)

- The doctor's actions were correct as such, but he might have pursued his sense of alarm somewhat further. (No. 17)

- Although the defendant did experience a sense of alarm, she nevertheless - not knowing what the problem was - failed to refer the patient. The tribunal considers this culpable negligence. (No. 20) 
- With hindsight, the defendant should have pursued her sense of alarm, but it is understandable that she did not, as she relied on the judgement of experienced colleagues. (No. 25)

- The baby's parents experienced a sense of alarm, which the doctor did not ignore. The doctor's examinations were in accordance with the rules. (No. 30)

- The doctor should have pursued his sense of alarm, and should have documented everything and passed this information on to the colleagues to whom he referred the patient. (No. 31)

- The doctor experienced a sense of alarm and acted accordingly in terms of diagnostics and management. (No. 34)

\section{Unjustified lack of sense of alarm}

- The repeated phone calls asking for a home visit... as well as the persistent fever and the other symptoms should have made the doctor realise that there might be a serious problem. No arguments have been produced to alter this conclusion. (No. 4)

- In the tribunal's opinion, the facts of the case-abnormal test results and edema of the ankle- should have induced a sense of alarm during the consultation, which should have resulted in an ultrasound examination being ordered. (No. 6)

- The defendant should have developed a sense of alarm, and he should have reacted more promptly and correctly to this sense of alarm once it arose. (No. 10)

- The defendant should have had an emerging sense of alarm, as this was the patient's fourth housecall, including two emergency visits. The doctor should at least have consulted a neurologist or should have urgently referred the patient. (No. 22)

- The patient's state of mind, characterized by agitation and fear, should have raised a sense of alarm in the doctor and should have induced him to visit the patient. (No. 14)

- The doctor should already have had a sense of alarm during the telephone conversation, rather than at the delayed house-call. (No. 28)

Justified lack of sense of alarm

- The doctor did not experience such an urgent sense of alarm that she considered calling a neurologist. The tribunal does not blame her for missing the correct diagnosis, but for failing to visit the patient immediately or consulting a neurologist. (No. 23)

- The lack of a sense of alarm does not constitute culpable negligence in the legal sense. The doctor's management is beyond reproach. (No. 26)

- The midwife had no cause to experience a sense of alarm. (No. 33)

- In the CTG's opinion, there was insufficient reason for a sense of alarm. (No. 24)

- The defendant claims that he had no sense of alarm and has acted with due care. (No. 27). The CTG appeal finds for the defendant.

\section{Other European countries}

We received information from 22 European countries. In most of them a central database with decisions of disciplinary tribunals is lacking or not accessible for research. A search of a database of decisions taken by the General Medical Council in the UK about the role of gut feelings in decisions of disciplinary tribunals, revealed no relevant cases. The search was done by information access managers using terms like "gut feelings", "sense or sensation of alarm", "feeling wrong", "uneasy feeling", "not feeling right", "not listening to feelings", "uncertainty" and "unsure". In France, gut feelings are not explicitly mentioned in the national Deontology Code and they were not referred to in the central database. (http://www.jurisprudence.ordre.medecin.fr/ jurisprudence/index.html). In Germany, no references to gut feelings or related topics were found in a database of medical tribunal judgments. (www.beck-online.de) In 
Denmark, the central databank with not all decisions from the Danish Patient Complaints Board (www.pkn.dk) offers a very limited publicly available number of cases but a search revealed no relevant cases.

\section{Discussion}

The decisions by Dutch medical disciplinary tribunals clearly indicate that the sense of alarm that is sometimes experienced by physicians, midwives, nurses or parents has to be taken seriously. The timely development of a sense of alarm is considered to be part of the professional standard for doctors, contributing to the quality of the health care they provide. This implies that a physician can be held liable for not developing a sense of alarm when there are clear indications, or for a failure to act on the basis of such a sense. Having a sense of alarm should be followed by extended history-taking and physical examination, and all case information must be carefully documented and handed over if the patient is transferred, to safeguard optimal care. In this sense, the sense of alarm, which is one aspect of the physicians' gut feelings, plays a substantial part in diagnostic reasoning, both by GPs and specialists. Whereas blaming a physician for not having had a sense of alarm when they should have may be difficult to accept for some doctors, describing the failure as an unjustified sense of reassurance may be more acceptable.

It is interesting to note that in hardly any of these cases was the health professional disciplined for missing the correct diagnosis. With hindsight, it may sometimes be rather easy to recognize the correct diagnosis. One might imagine that a lack of professional knowledge would have been part of the reproach. However, the professionals were only reproached for failing to act professionally in situations in which clear indications were present that there was something seriously wrong with their patient. Apparently, professional behaviour primarily includes thorough historytaking and physical examination, and weighing up the signs and symptoms against the possibility of serious disease. ${ }^{10}$ The tribunals do not expect doctors to always establish correct diagnoses.

Although all decisions taken by the Dutch Central Disciplinary Tribunal in 2000-2008 are included in the database we searched, not all decisions taken by Regional Tribunals during the first years of their existence have been made available in digital form. Still, 34 cases seem enough to gain a reliable idea how tribunals evaluate gut feelings, although our search might have missed comparable cases where the typical Dutch expression for a sense of alarm was not used, but only some descriptive phrase. A search using key words of our description, ${ }^{1,2}$ however, found only one new comparable case.

Two-thirds of all decisions we studied involved GPs (Table 6.1). Over the 1997-2006 period, the total number of decisions by medical tribunals in the Netherlands was 9387, including the unpublished decisions; 2042 (22\%) involved GPs. ${ }^{10}$ The 
overrepresentation of GPs in our study can be explained by their frontline position in the Dutch national health care system. Dutch GPs do not work in hospitals but instead act as gatekeepers, seeing many people with vague, incompletely developed and mostly self-limiting complaints. In these situations of diagnostic uncertainty, ${ }^{11}$ GPs weigh up the presenting signs and symptoms against the background of their contextual knowledge of the patient, mostly without X-ray or lab results, and gut feelings may play a substantial part in their diagnostic reasoning. ${ }^{1,12}$ Dutch GPs, like those in several other countries, often see their patients over many years, and thus

know much about their medical and family history and social background. ${ }^{13,14}$ This contextual knowledge is a major determinant of gut feelings in general practice. Patients referred by GPs to specialists often have clearer signs and symptoms and more fully developed clinical pictures, while the easy access that specialists have to high-tech equipment also reduces the diagnostic uncertainty.

The percentage of disciplinary measures in first instance judgements (56\%) was higher in our cases than the average of $42 \%$ (http://www.tuchtcollege-ezondheidszorg.nl/ Images/ Jaarverslag\%202008_tcm37-29660.pdf). These cases thus clearly indicate that in the opinion of the tribunals, a sense of alarm should not be ignored, even when no clear diagnosis can as yet be established, since ignoring a sense of alarm may have serious consequences for both patient and GP.

The limited results of our searches in some other European countries are inconclusive. Relevant data are not easily accessible for research, if at all. Still, this exploratory investigation seems to indicate that the significance of the role of gut feelings is especially acknowledged by the Dutch tribunals, even though gut feelings are a common phenomenon in general practice all over Europe. This may in part be a matter of culture or professional language or caused by the current lack of validity data. It would be worthwhile to compare in greater detail how the tribunals in various European countries develop standards of good professional behaviour.

\section{Conclusion}

We conclude that the sense of alarm as a diagnostic tool has been taken seriously by Dutch disciplinary tribunals over the last nine years, although the first results of research into the value of gut feelings have only just been published. The fact that the tribunals' decisions rarely offer any descriptions of the term indicates that this assumed to be a well-known concept among physicians. The timely development of a sense of alarm is considered to be an element of the professional standards for doctors. It has to be followed by extensive history-taking and physical examination, weighing up the presented signs and symptoms against the possibility of serious disease, and all information must be carefully documented and handed over if the patient is transferred, in order to safeguard optimal care. In fact, not developing a sense of alarm when there are clear indications is in itself considered reprehensible. If 
they feel a sense of alarm, physicians are obliged to exclude serious diseases to the best of their ability. Missing a diagnosis is not always reprehensible, but failing to act professionally certainly is. Further research on this topic in other countries is necessary. 


\section{References}

1. Stolper CF, Van Bokhoven MA, Houben PHH, Van Royen P, Van de Wiel M, Van der Weijden T, Dinant G.J. The diagnostic role of gut feelings in general practice. A focus group study of the concept and its determinants. BMC Fam Pract 2009;10:17.

2. Stolper CF, Van Royen $\mathrm{P}$, Van Bokhoven MA, Houben PHH, Van de Wiel M, Van der Weijden T, Dinant GJ. Consensus on gut feelings in general practice. BMC Fam Pract 2009;10:66.

3. Grossman SC, Wheeler K. Predicting patients' deterioration and recovery. Clin Nurs Res 1997;6:45-58.

4. Hams SP. A gut feeling? Intuition and critical care nursing. Intensive Crit Care Nurs 2000;16:310-8.

5. Nordberg M. Just a gut feeling. Emerg Med Serv 1996;25:31, 34-40.

6. Eraut M. Expert and expertise: meanings and perspectives. Learning in Health and Social Care 2005;4:173-9.

7. Buntinx F, Truyen J, Embrechts P, Moreel G, Peeters R. Chest pain: an evaluation of the initial diagnosis made by 25 Flemish general practitioners. Fam Pract 1991;8:121-4.

8. Van den Bruel A. The value of signs and symptoms for the diagnosis of serious infections in children in primary care. Catholic University Leuven Belgium. 2006.

9. Lykke K, Christensen P, Reventlow S. "This is not normal ... "--signs that make the GP question the child's well-being. Fam Pract 2008;25:146-53.

10. Van Leusden MB, Jongerius P, Hubben JH. GPs and disciplinary procedures [Huisarts en Tuchtrecht 1997 - 2007]. Den Haag: Sdu, Uitgevers BV. 2008.

11. Dinant GJ. Diagnosis and decision. Undifferentiated illness and uncertainty in diagnosis and management. In: Jones R, Britten N, Gulpepper L, Gass D, Grol R, Mant D, Silagy C, editors. Oxford Textbook of Primary Medical Care.Oxford: Oxford University Press. 2004:201-3.

12. Baerheim A. The diagnostic process in general practice: has it a two-phase structure? Fam Pract 2001; 18:243-5.

13. Hjortdahl P. The influence of general practitioners' knowledge about their patients on the clinical decision-making process. Scand J Prim Health Care 1992;10:290-4.

14. Hjortdahl P. Continuity of care. In: Jones R, Britten N, Culpepper L, Gass DA, Grol R, Mant D, Silagy C, editors. Oxford Textbook of Primary Medical Care. Volume 1 Principles and Concepts.Oxford: Oxford University Press; 2004:249-52. 

any

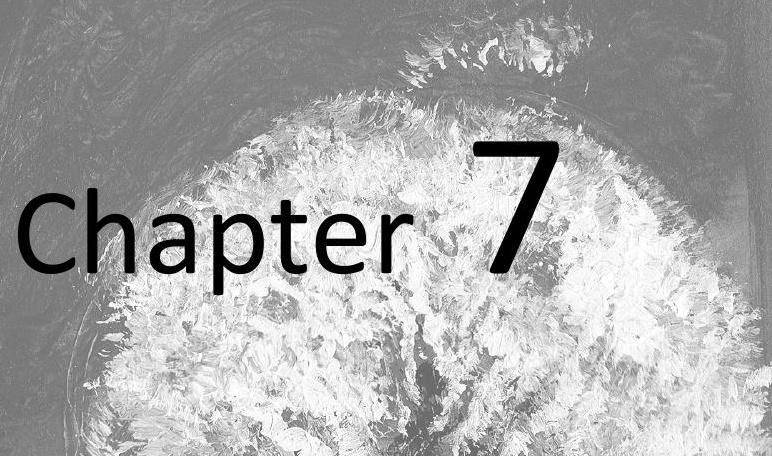

Gut feelings as a third track in general practitioners'

diagnostic reasoning

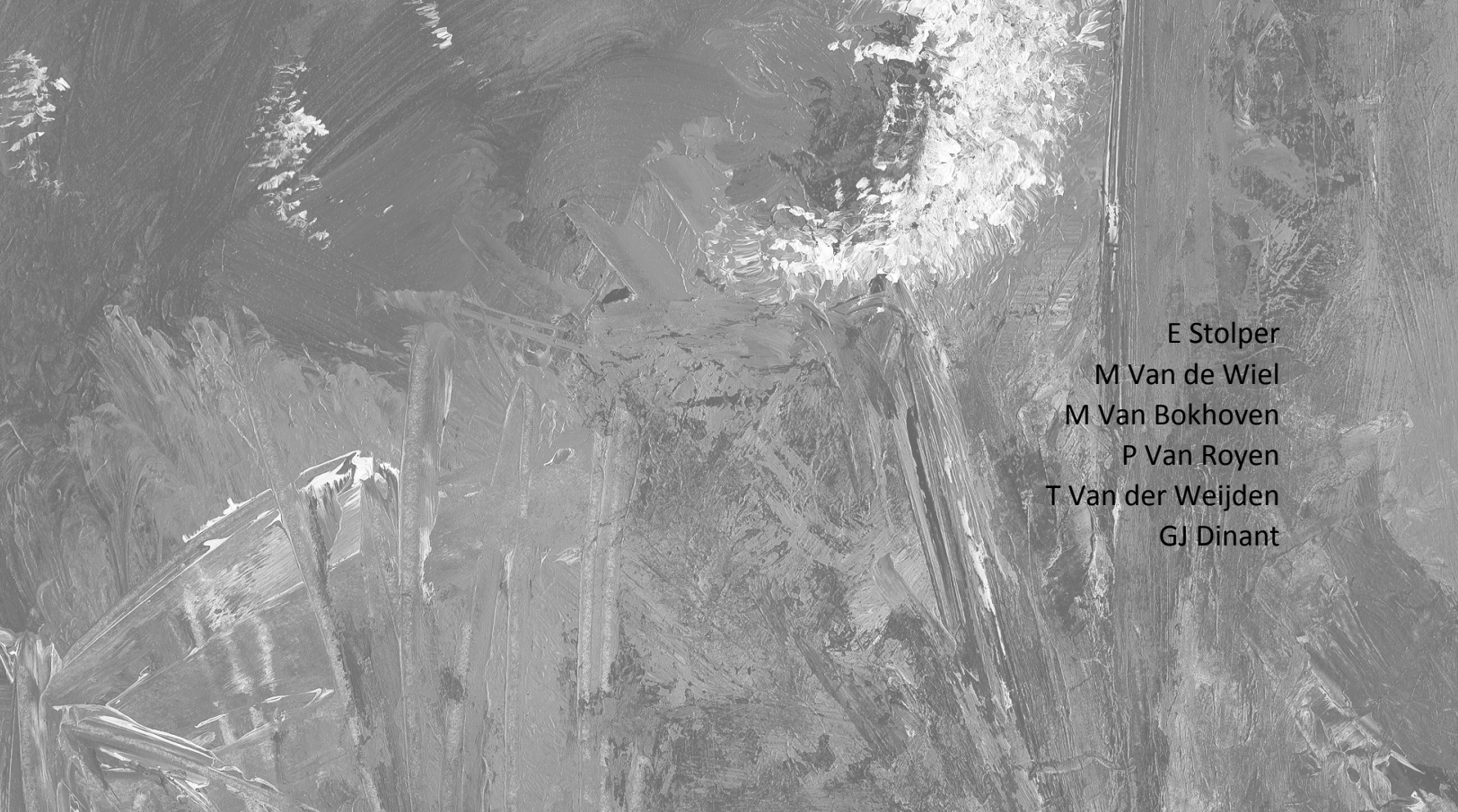




\section{Abstract}

\section{Purpose}

General practitioners (GPs) are often faced with complicated, vague problems in situations of uncertainty which they have to solve at short notice. In such situations, gut feelings play a substantial role in their diagnostic process as earlier research found. Two types of gut feelings have been distinguished: a sense of alarm and a sense of reassurance. However, not every GP trusts his or her gut feelings since a scientific explanation is lacking. This paper explores how gut feelings arise and function in GPs' diagnostic reasoning as a third track, next to the well-known tracks of medical problem-solving and medical decision-making.

\section{Methods}

The paper reviews literature on diagnostic reasoning from various perspectives as well as psychological theories of dual processing.

\section{Results and conclusions}

The well-defined processes of analytical and non-analytical reasoning and the insights from dual process theories enabled us to construct a model of the diagnostic reasoning process which integrates the three diagnostic tracks. Analytical and non-analytical diagnostic reasoning interact continuously, and GPs may simultaneously use elements of all three tracks, depending on the task and the situation. The role of affect as a heuristic within the physician's knowledge network explains how gut feelings may help GPs to navigate in a mostly efficient way in the often complex and uncertain diagnostic situations of general practice. The implications for medical education and research are discussed. 


\section{Introduction}

Most general practitioners (GPs) will recognize that feeling of sudden heightened awareness or alarm, which sometimes emerges during a consultation: "There's something wrong with this patient but I don't know exactly what. I have to do something because a delay can be harmful" ${ }^{1-3}$ These so-called gut feelings seem to play a part in the diagnostic process of general practitioners (GPs) when symptoms are vague, undifferentiated or at an early stage of a patient's illness. However, this role has hardly been studied and is not well understood either. Focus group research into gut feelings in general practice found that many GPs trust their gut feelings which act as a compass, steering GPs through busy office hours and enabling them to handle complex problems. ${ }^{4}$ A GP in one of the focus groups told about how he was irritated when a young man entered his consultation room late on a Friday afternoon with only a common cold and a sore throat. Suddenly, however, he had the feeling there was something wrong with this patient, although he did not know why. He examined him, found an enlarged spleen and referred the patient to the hospital. It turned out that he had leukaemia. "It was the first time in my life", said this GP, "that I examined an abdomen of a patient with just a sore throat, but my gut feelings told me that something did not fit in. In hindsight, I suppose it had something to do with the colour of his face". However, some GPs in the focus groups distrusted their intuitive gut feelings because they viewed them as irrational. As a GP said: "You get all kinds of information, and it's tempting to draw a conclusion, but you absolutely have to force yourself not to do that, to remain at a rational level, as I think gut feelings are a major pitfall". Yet another GP said: "As GPs, I think we need to be aware of the way we think, the way we establish a diagnosis, and that we have to specify that process and make it objective, without resorting to something as unreliable as gut feelings". These GPs represented the view that there is no scientific explanation for the way they originate.

A Delphi consensus procedure with GPs or ex-GPs involved in academic educational or in research programmes corroborated the two types of gut feelings that were described in the focus groups: a sense of alarm and a sense of reassurance. ${ }^{5}$ The "sense of alarm" implies that a GP worries about a patient's health status, even though they have found no specific indications yet; it is a sense of "there's something wrong here". It means that the GP needs to initiate specific management to prevent serious health problems. The "sense of reassurance" means that a GP feels secure about the further management and course of a patient's problem, even though they may not be certain about the diagnosis: "everything fits in".

Dealing with uncertainty and unpredictability is a characteristic part of medical practice in complex situations ${ }^{6-8}$ triggering gut feelings. ${ }^{9-14}$ The role of gut feelings in GPs' diagnostic reasoning has become much clearer but a scientific understanding is still lacking. To explain this role, we present a model of the diagnostic process, in which the role of gut feelings as a non-analytical mode of reasoning has been added 
to the well-defined diagnostic tracks of medical problem-solving and medical decisionmaking. ${ }^{15}$ This model with three diagnostic tracks can help us understand gut feelings and explore their position in medical curricula.

Based on Elstein's and Schwarz's selective review, ${ }^{15}$ we first discuss the two main tracks of diagnostic reasoning, medical problem-solving and medical decision-making, focusing on analytical and non-analytical processes. We then review the diagnostic process and the role of gut feelings in the light of current psychological theories of dual processing. Finally, we will discuss the implications of our model for daily practice, medical education and research.

\section{Medical problem-solving}

Physicians can be regarded as medical detectives since the analysis of signs and symptoms may lead them to the correct diagnosis. ${ }^{16}$ This diagnostic reasoning, described as generating and testing hypotheses and known as the hypotheticodeductive method $^{17-20}$ has not been found to differ between successful and unsuccessful diagnosticians, nor between experts and novices. ${ }^{19,21}$ The difference between them arise from the underlying knowledge base that enables experienced physicians, in routine cases, to automatically retrieve the correct diagnostic hypotheses based on only a few relevant signs and symptoms. ${ }^{19,22-24}$ Their knowledge also guides them in an efficient information search and treatment planning. The direct retrieval of relevant knowledge is an automatic, non-analytical process which, in the case of diagnosis, is often referred to as pattern recognition. ${ }^{15,25}$ It implies that clinicians do not reason analytically with signs and symptoms, but immediately understand a patient's problem in diagnostic terms. This might be based on an automatic information integration process such as categorization and problem representation ${ }^{15,26-28}$ or on the instant recognition of similarity to a previously seen case stored in memory. ${ }^{25,29}$

The knowledge structures underlying the categorization of a patient's characteristics as related to a particular disease are often described as prototypes and illness scripts. ${ }^{30-33}$ They can function both at an analytical and non-analytical level, depending on the availability and accessibility of a diagnosis given the patient's information. In analytical processing, features are listed and weighed up when they are mapped to diseases. Contextual factors such as age, gender, prior medical history and drug use play an important role in family medicine (as enabling conditions) in generating accurate diagnostic hypotheses since they may make the presence of a disease more likely. $^{34}$

Another analytical process that might be invoked in medical problem solving is causal reasoning with biomedical knowledge. ${ }^{25,30,35}$ This type of analysis is often used by medical students who have learned about disease and the underlying pathophysiological processes, but who lack the clinical experience to instantaneously 
recognize a patient's problem. ${ }^{36}$ It is also a fall-back mechanism for experienced physicians when they are confronted with difficult or complex cases ${ }^{24,37,38}$ and data. ${ }^{24,39}$ If we conceptualize expert medical knowledge as a large and highly coherent but associative network in which contextual information, signs and symptoms, causes of disease, pathophysiological mechanisms and high-level clinical concepts in the form of diagnostic labels are represented, ${ }^{25,27,30}$ we can explain the use of biomedical knowledge as and when necessary in diagnostic reasoning. As physicians diagnose routine cases, the relevant clinical concepts become activated, resulting in direct clinical associations bypassing biomedical knowledge. But in difficult and complex cases, this non-analytical process fails and more detailed biomedical knowledge might be used to bridge the gaps between the elements in the clinical picture. Biomedical knowledge might also be used in explaining or checking the outcomes of nonanalytical processes. ${ }^{40}$

As medical expertise develops, knowledge structures become richer, more diversified (causal networks, prototypes, illness scripts, specific cases), better coordinated, and attuned to the patients encountered, so the right knowledge will be activated at the right time. ${ }^{25,27,30,41}$ With experience, therefore, clinical reasoning becomes more automatic and non-analytical allowing fast and efficient diagnosis and treatment while the rich knowledge base can be accessed, if necessary, in a more deliberate and analytical way.

Gut feelings can be explained as the result of non-analytical reasoning in medical problem-solving. It is the outcome of a quick scan, in which a patient's current picture is compared with the overall picture the GP expects from their knowledge about this patient and about diseases. Does it fit in or not? ${ }^{4} A$ sense of reassurance arises when pattern indicates that the clinician trusts their hypothesis or problem definition. A sense of alarm arises when patterns do not match and the clinician cannot form a coherent interpretation of the case.

\section{Intuition, problem-solving and expertise}

Whereas the literature discussed above does not use intuition as a concept, the role of intuition in medical problem-solving is explicitly addressed in other traditions. ${ }^{42-45}$ In the cognitive continuum theory, intuition and analysis are defined as two modes of cognition that can be placed at the ends of a continuum, where intuition refers to rapid, unconscious processing and low control, and analysis refers to slow, conscious and controlled processing. ${ }^{45,46}$ A lot of thinking falls somewhere in between and the appropriate mode of thought depends on the specific task characteristics. Doctors need to match the cognitive processes to the task requirements to be accurate. In their theory of expertise, Dreyfus and Dreyfus emphasize that expertise develops with experience and thinking proceeds in several stages from analytical to almost completely intuitive. ${ }^{42}$ Intuitive judgment is seen here as the hallmark of expertise. Both approaches fit in with the above view that the task in interaction with the 
physician's knowledge structures determines whether reasoning will be automatic and fast, i.e. intuitive, or analytical.

Intuitive processes are so fast that one just knows or acts without being aware where the thought or action comes from. The knowledge on which it is based is not directly accessible and in any case not explicitly used. Hence it is referred to by some authors as tacit knowledge. ${ }^{43,47,48}$ Polanyi introduced this term to emphasize that personal knowledge is built on a wealth of experiences that is not verbalizable: "that which we know but cannot tell". ${ }^{47,49}$ It is tied to the practices from which it is acquired, and often results from informal and implicit learning. ${ }^{43,50}$ This experiential knowledge is part of the highly interconnected network of knowledge of medical experts, ${ }^{50}$ and may lead to both routine action and reflection. ${ }^{51}$ "Not feeling right", for example, is the outcome of an implicit monitoring process that may trigger immediate intervention, further thinking or even deliberate learning, depending on the situation. ${ }^{43}$

The role of intuition in diagnostic reasoning has been extensively investigated in nursing and results show that intuition is an integrated part of nurses' decisionmaking ${ }^{9,11,52-55}$ It is assumed to be based in expert knowledge and explained by theories referred to above. ${ }^{42,51,53,56-58}$

Intuition can thus be explained as the outcome of highly personalized knowledgebased processes that may help physicians and nurses deal with the complexity of the tasks they face. ${ }^{44}$ We assume that gut feelings in general practice are similar to intuition but more specific as they are confined to prognostic assessments of the patient's situation, often accompanied by bodily sensations. ${ }^{4,5}$

\section{Medical decision-making}

Medical decision-making models (MDM) make use of Bayes theorem, likelihood ratios, prior and posterior odds, thresholds, schemes and decision trees to arrive at the best diagnostic and therapeutic decisions. ${ }^{15,59-62}$ These mathematical models, incorporating clinical epidemiological data, are related to the concept of evidence based medicine (EBM) and constitute a norm for best practice. It is assumed that these models help physicians avoid cognitive biases and mistakes that arise by relying on ones own accumulated knowledge base. ${ }^{15,63-66}$ The MDM literature emphasizes that intuitions may be false and therefore advocates the use of analytical models and decisions aids, as well as the monitoring of intuitive ideas by checking for biases before deciding.

In contrast to the problem-solving approach, MDM does not focus on the virtues of experience and expertise, but on the pitfalls. For example, the domain specificity of expertise can be a handicap when physicians diagnose a patient with a disease related to but outside their speciality, as they impose their prior knowledge on the situation. ${ }^{67}$ They interpret the case from their frame of reference, activating hypotheses that fit with diseases they usually see rather than with the hypotheses proposed by real 
specialists. The problem is that the ideas that first spring to mind determine further thinking and action, so other relevant information, such as the base rates in a population, may be neglected or only data confirming the current hypothesis may be considered and sought. The feeling of knowing, in the sense of having great confidence in one's own judgment, is what we described as the sense of reassurance. Doctors are sometimes incorrectly reassured when they prematurely close the diagnostic or therapeutic process without critically searching for novel conflicting information or weighing up evidence from the literature. ${ }^{68,69}$

In the majority of cases, however, experience lead to adaptive and efficient performance in practice, ${ }^{15,18}$ and deliberate control over the outcomes of automatic processes can be short and guided by routine when there are no reasonable doubts about their value. Moreover, the use of analytical methods is not without errors either, as experts often have to enter the values into formulas based on their subjective evaluations or make errors of calculation. ${ }^{46,70}$ In making decisions, clinicians also use non-analytical knowledge. Clinicians are Bayesians by nature in their diagnostic reasoning, and the patient's history, signs and symptoms are powerful tests updating prior probabilities ${ }^{71}$ but GPs do not calculate a running tally of likelihood ratios. ${ }^{72-74}$ Relying on their knowledge of patients, on their expertise and an often intuitive assessment of prior probabilities, usually expressed in an ordinal scale from very unlikely to almost certain, GPs add evidence to a prior probability instead of multiplying evidence with a prior chance. ${ }^{75,76}$ Furthermore, the power of a diagnostic indicator to confirm or exclude is mostly assessed in terms like insignificant, weak, good, strong or very strong, and physicians usually assess decision thresholds when deciding to wait, initiate further examinations or take action. ${ }^{62,77}$

Evidence-based medicine (EBM) originally closely followed the MDM approach ${ }^{78}$, but now stands for "integrating individual clinical expertise with the best available external clinical evidence from systematic research". ${ }^{79}$ Scientific evidence alone is not an adequate guide, as based on their expertise and skills clinicians need to acquire and integrate information on the condition of the individual patient, his or her preferences, and the best evidence. ${ }^{79}$ The patient's problem is the starting point to search for answers to clinically relevant questions in appropriate sources, and the clinician has to decide whether to apply the findings to this individual patient. ${ }^{80} \mathrm{New}$ evidence will be integrated in the knowledge networks of experts and can later be applied. Thus, in taking medical decisions, practitioners have to find a balance between analytical and non-analytical reasoning, based on their explicit and tacit knowledge ${ }^{81}$ of clinical medicine, their patients, and the value of evidence and analytical tools. The critical question is when to trust intuition and when to revert to more formal reasoning. ${ }^{70,82}$ 


\section{Analytical versus non-analytical reasoning: a dual process}

Analytical, rule-based reasoning and non-analytical, experiential reasoning are contrasted as two modes of knowing and thinking in psychological dual-process theories. ${ }^{3,83-86}$ The analytical system is explicit, controlled, rational, effortful and relatively slow. In clinical reasoning, analytical thinking is present in hypotheticodeductive diagnostic processes, in causal reasoning with biomedical knowledge and when using decision tools. The non-analytical system is implicit, based on tacit, automatic and effortless thought processes and is associative, intuitive and fast. Nonanalytical reasoning can be recognized both in medical problem-solving and in medical decision-making, for instance in pattern recognition and in automatic assessment processes of chances and in gut feelings. When automatic processes do not lead to clear hypotheses, the similarity or discrepancy with what is known about a patient or disease may induce a sense of reassurance or a sense of alarm. The interaction between these two systems determines the output of the whole thinking process. The outcomes of the non-analytical system can be reflected upon by the analytical system and accepted or elaborated upon for further understanding and investigation or to provide explanations. ${ }^{84}$

\section{Affect}

The role of affect in non-analytical processes has been acknowledged in some dualprocess theories. ${ }^{86}$ Affect as a state of feeling (whether conscious or subconscious) means a positive feeling of "goodness" or a negative one of "badness" and is assumed to have become attached by experience to knowledge represented in images, metaphors and narratives. As a heuristic or mental shortcut it automatically facilitates associative processes. ${ }^{84,86-88}$ Affective responses occur rapidly and somewhere along the line the "good" or "bad" feelings guide the thinking process, helping people to navigate, in a mostly efficient way, in complex, uncertain and sometimes dangerous situations. ${ }^{89}$ Thus analytical and non-analytical systems are both active, continually interacting in what has been characterized as "the dance of affect and reason". ${ }^{88}$ GPs very often face uncertain and complex situations where they have to assess their patients' health risk. Gut feelings, which GPs may experience in their diagnostic reasoning process, can be understood as a part of the affect heuristic, and may enable them to distinguish between situations where "something is wrong", even without specific indications, and those where they may be secure about the further management and course of a patient's problem, even though they are unsure about the diagnosis. Since the affect heuristic is supposed to act at a sometimes subconscious level, this explains why GPs are not always aware of their sense of reassurance unless they reflect upon their diagnostic reasoning. ${ }^{4}$

The reason why GPs often perceive the sense of alarm as a physical sensation in the abdomen or the heart ${ }^{4}$ can be explained by "the somatic marker hypothesis". ${ }^{90}$ It is 
supposed that images stored in one's knowledge become "marked" through experience by positive or negative feelings directly or indirectly linked to bodily states. A negative somatic marker sounds a bodily experienced alarm when a linked image of a future outcome is activated and, conversely, a positive somatic marker associated with a positive image triggers a good or secure feeling.

\section{Diagnostic reasoning model}

To conclude, we present a model to visualize GPs' diagnostic reasoning as a mix of analytical and non-analytical reasoning processes (see Figure 7.1) where the three tracks of diagnostic reasoning, medical decision-making, medical problem-solving and gut feelings, collaborate within the knowledge network. Depending on the task (routine or more complicated) and the situation (being familiar with a patient and a disease or not) GPs simultaneously use elements of all three tracks. With increasing experience, their knowledge network will become richer and more coherent and nonanalytical reasoning will more often be invoked, but experienced GPs are able to switch to analytical reasoning when the automatic approach is not enough to explain the patient's situation. The sense of alarm can be regarded as the first warning sign that automatically pops up from the knowledge network, to slow down when necessary. ${ }^{82}$ Sometimes no satisfactory explanation can as yet be found, but prompt intervention is necessary bypassing a diagnosis. And sometimes GPs can feel reassured about the expected course of an illness even if they have as yet no clear diagnosis.

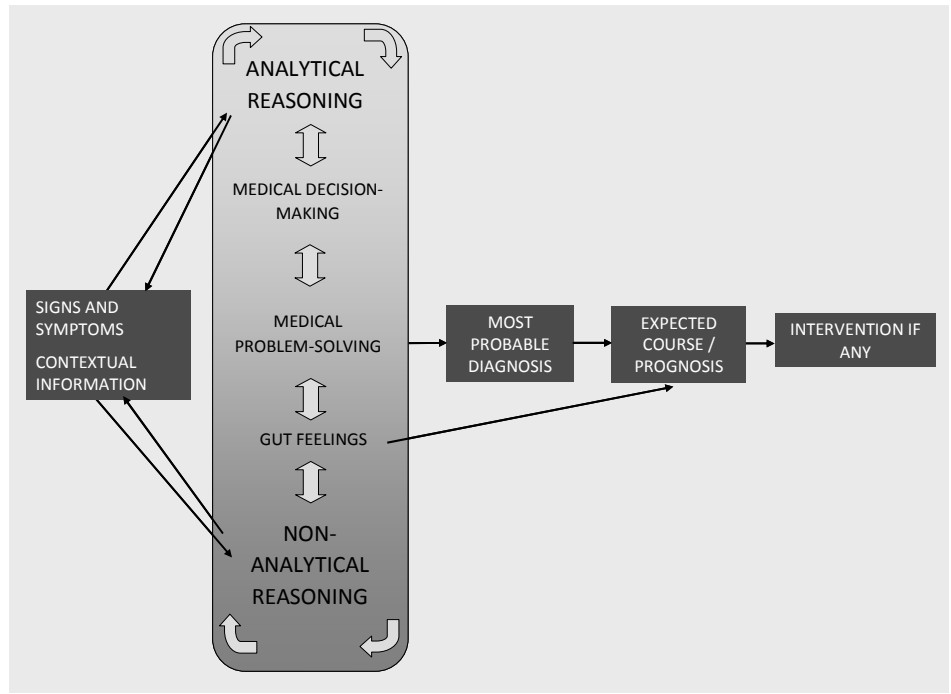

Figure 7.1 Knowledge-based model of GPs' diagnostic reasoning. 


\section{Implications}

Many discussions in the literature about the role of intuition versus rational decisionmaking in medicine have ended with a normative conclusion: use mostly rational thinking since intuitive hunches have often proved to be incorrect or less effective. ${ }^{91,92}$ But this dilemma does not make sense and such discussions are fruitless, since they overlook the contributions of the expert knowledge network. We particularly want to emphasize that the interaction between analytical and non-analytical reasoning is vital in diagnostic thinking and both strategies should be learned in this interactive fashion. ${ }^{17,18,82}$ The implications for teaching could be an extended attention for awareness and acknowledgement of diagnostic feelings, and for indicators to slow down switching to analytical reasoning. However, medical educators mostly teach students to reason in an analytical way, and when doctors explain their diagnostic reasoning for a patient's problem they usually make it seem like a logical hypotheticodeductive process or the result of a decision-making model. Unfortunately, this retrospective reconstruction of seemingly objective reasoning sometimes excludes the tacit clues and intuitive hunches hidden in the patient's story on which the original diagnosis depended. It also denies the coordinated processes of analytical and nonanalytical reasoning in which gut feelings play a substantial part. Knowing the patient's narrative and its interpretation by the experienced physician can help medical students to understand both aspects of diagnostic reasoning. ${ }^{93,97}$ "Reflectionin-action" by the physician will contribute to an understanding of this complex process. $^{51,98,99}$

GPs often follow their patients over many years, and thus know much about their history and background. ${ }^{100,101}$ This contextual knowledge as a frame of reference is a characteristic of general practice, enabling doctors to compare what they already know with the present picture..$^{34,102,103}$ Since this contextual knowledge has proved to be an important determinant of gut feelings ${ }^{4}$ such feelings function well in the sometimes unclear and complex diagnostic situations of general practice where GPs have to judge under uncertainty.

Further research should establish the diagnostic value of gut feelings, and test ways to integrate the use of non-analytical reasoning in medical education.

\section{Conclusion}

GPs are often faced with complicated, vague problems which they have to solve at short notice. Our model of GPs' diagnostic reasoning (see Figure 7.1), emphasizes that analytical and non-analytical cognitive processes are combined in this complex task. It integrates the two well-known diagnostic reasoning tracks of medical decision-making and medical problem-solving, and explains how gut feelings arise as a third track. In a dual process theory, gut feelings emerge as a consequence of non-analytical 
processing of all available information and knowledge, reassuring GPs that they are on the right track, or alerting them that something is wrong and action is required. The role of gut feelings at the intersection of the two processes is substantial and intriguing. 


\section{References}

1. Hull F. The consultation process. In: Sheldon M, Brooke J, Rector A, editors. Decision Making in General Practice.London: Macmillan. 1985:13-26.

2. Andre M, Borgquist L, Foldevi M, Molstad S. Asking for 'rules of thumb': a way to discover tacit knowledge in general practice. Fam Pract 2002;19:617-22.

3. Boreham NC. The dangerous practice of thinking. Med Educ 1994;28:172-9.

4. Stolper CF, Van Bokhoven MA, Houben PHH, Van Royen P, Van de Wiel M, Van der Weijden T, Dinant G.J. The diagnostic role of gut feelings in general practice. A focus group study of the concept and its determinants. BMC Fam Pract 2009;10:17.

5. Stolper CF, Van Royen P, Van Bokhoven MA, Houben PHH, Van de Wiel M, Van der Weijden T, Dinant GJ. Consensus on gut feelings in general practice. BMC Fam Pract 2009;10:66.

6. Dinant GJ. Diagnosis and decision. Undifferentiated illness and uncertainty in diagnosis and management. In: Jones R, Britten N, Gulpepper L, Gass D, Grol R, Mant D, Silagy C, editors. Oxford Textbook of Primary Medical Care.Oxford: Oxford University Press. 2004:201-3.

7. Griffiths F, Green E, Tsouroufli M. The nature of medical evidence and its inherent uncertainty for the clinical consultation: qualitative study. BMJ 2005;330:511.

8. Innes AD, Campion PD, Griffiths FE. Complex consultations and the 'edge of chaos'. Br J Gen Pract 2005;55:47-52.

9. Rew L, Barrow EM, Jr. State of the science: intuition in nursing, a generation of studying the phenomenon. ANS Adv Nurs Sci 2007;30:E15-E25.

10. Nordberg M. Just a gut feeling. Emerg Med Serv 1996;25:31, 34-40.

11. Hams SP. A gut feeling? Intuition and critical care nursing. Intensive Crit Care Nurs 2000;16:310-8.

12. Barraclough K. Medical intuition. BMJ 2006;332(497).

13. Hall KH. Reviewing intuitive decision-making and uncertainty: the implications for medical education. Med Educ 2002;36:216-24.

14. Greenhalgh T. Intuition and evidence-uneasy bedfellows? Br J Gen Pract 2002;52:395-400.

15. Elstein AS, Schwarz A. Clinical problem solving and diagnostic decision making: a selective review of the cognitive literature. BMJ 2002;324:729-32.

16. Osborn J. Observation, Sherlock Holmes, and Evidence Based Medicine. Med Secoli 2002;14:515-27.

17. Bowen JL. Educational strategies to promote clinical diagnostic reasoning. N Engl J Med 2006;355:2217-25.

18. Eva KW. What every teacher needs to know about clinical reasoning. Med Educ 2004;39:98-106.

19. Elstein AS, Shulman L, Sprafka S. Medical Problem Solving: an analysis of clinical reasoning. Cambridge, Mass.: Harvard University Press. 1978.

20. Dinant GJ, Van Leeuwen YD. Diagnosis and decision-making. Clinical diagnosis: hypothetico-deductive reasoning and other theoretical frameworks. In: Jones R, Britten N, Culpepper L, Gass D, Grol R, Mant D, Silagy C, editors. Oxford Textbook of Primary Medical Care. Oxford: Oxford University Press. 2004:203-5.

21. Neufeld VR, Norman GR, Feightner JW, Barrows HS. Clinical problem-solving by medical students: a cross-sectional and longitudinal analysis. Med Educ 1981;15:315-22.

22. Feltovich PJ, Barrows HS. Issues of generality in medical problem solving. In:Tutorials in problembased learning. A new direction in teaching the health professions. Assen: Van Gorcum. 1984.

23. Patel VL, Groen GJ. Knowledge based solution strategies in medical reasoning. Cogn Science 1986;10:91-116.

24. Lesgold AM, Rubinson H, Feltovich PJ, Glaser R, Klopfer R, Wang Y. Expertise in a complex skill; diagnosing X-ray pictures. In: Chi MTH, Glaser R, Farr MJ, editors. The nature of expertise.Hillsdale, New Jersey: Lawrence Erlbaum Associates. 1988:311-42.

25. Norman GR, Eva K, Brooks LR, Hamstra S. Expertise in Medicine and Surgery. In: Ericsson KA, Charness N, Feltovich PJ, Hoffman RR, editors. The Cambridge Handbook of Expertise and Expert Performance.New York: Cambridge University Press. 2006:339-54.

26. Bordage G, Lemieux M. Semantic structures and diagnostic thinking of experts and novices. Acad Med 1991;66(9 Suppl):S70-S72. 
27. Van de Wiel M, Boshuizen HPA, Schmidt H. Knowledge restructuring in expertise development: Evidence from pathophysiological representations of clinical cases by students and physicians. Eur J Cogn Psych 2000;12:323-55.

28. Van de Wiel M, Szegedi KHP, Weggeman CDP. Professional learning: Deliberate attempts at developing expertise. In: Boshuizen HPA, Bromme R, Gruber H, editors. Professional Learning: Gaps and transitions on the way from novice to expert.Dordrecht: Kluwer, The Netherlands. 2004:181-206.

29. Norman G, Young M, Brooks L. Non-analytical models of clinical reasoning: the role of experience. Med Educ 2007;41:1140-5.

30. Schmidt HG, Norman GR, Boshuizen HP. A cognitive perspective on medical expertise: theory and implication. Acad Med 1990;65:611-21.

31. Charlin B, Boshuizen HP, Custers EJ, Feltovich PJ. Scripts and clinical reasoning. Med Educ 2007;41:1178-84.

32. Bordage G. Elaborated knowledge: a key to successful diagnostic thinking. Acad Med 1994;69:883-5.

33. Bordage G. Prototypes and semantic qualifiers: from past to present. Med Educ 2007;41:1117-21.

34. Hobus PP, Schmidt HG, Boshuizen HP, Patel VL. Contextual factors in the activation of first diagnostic hypotheses: expert-novice differences. Med Educ 1987;21:471-6.

35. Woods NN. Science is fundamental: the role of biomedical knowledge in clinical reasoning. Med Educ 2007;41:1173-7.

36. Schmidt HG, Boshuizen HPA. On acquiring expertise in medicine. Educational Psychology Review 1992;5:1-17.

37. Patel VL, Groen GJ, Arocha JF. Medical expertise as a function of task difficulty. Mem Cognit 1990;18:394-406.

38. Norman GR, Trott AD, Brooks LR, Smith EKM. Cognitive differences in clinical reasoning related to postgraduate training. Teaching and Learning in Medicine 1994;6:114-20.

39. Gilhooly KJ, McGeorge P, Hunter J, Rawles JM, Kirby IK, Green C, et al. Biomedical knowledge in diagnostic thinking: The case of electrocardiogram (ECG) Interpretation. Eur J Cogn Psych 1997;9: 199-223.

40. Van de Wiel M, Boshuizen HPA, Schmidt HG, Schaper N. The explanation of clinical concepts by expert physicians, clerks, and advanced students. Teaching and Learning in Medicine 1999;11:153-63.

41. Schmidt HG, Rikers RM. How expertise develops in medicine: knowledge encapsulation and illness script formation. Med Educ 2007;41:1133-9.

42. Dreyfus H.L, Dreyfus S.E. Mind over machine: The power of human intuition and expertise in the era of the computer. Oxford. 1986.

43. Eraut M. Non-formal learning and tacit knowledge in professional work. $\mathrm{Br} \mathrm{J}$ Educ Psychol 2000;70:113-36.

44. Abernathy CM, Hamm RM. Surgical intuition: What it is and how to get it. Philadelphia. 1995.

45. Hamm RM. Clinical intuition and clinical analysis: Expertise and the Cognitive Continuum. In: Dowie J, Elstein A, editors. Professional judgement. A reader in clinical decision making.Cambridge: Cambridge University Press. 1988:78-104.

46. Hammond KR, Hamm RM, Grassia JL, Pearson T. Direct comparision of the efficacy and analytical cognition in expert judgement. IEEE Transactions on Systems, Man and Cybernetics ed. 1987.

47. Polanyi M. The Tacit Dimension. London: Routledge and Kegan Paul. 1967.

48. Sternberg RJ, Horvath JA. Tacit knowledge in professional practice: Researcher and practitioner perspectives. Mahwah,N.J.: Lawrence Erlbaum. 1999.

49. Henry SG. Recognizing tacit knowledge in medical epistemology. Theor Med Bioeth 2006;27:187-213.

50. Patel VL, Arocha JF, Kaufman DR. Expertise and tacit knowledge in medicine. In: Sternberg RJ, Horvath $\mathrm{JA}$, editors. Tacit knowledge in professional practice: Researcher and practitioner perspectives. Mahwah N.J.:Lawrence Erlbaum. 1999:75-120.

51. Schon D. The reflective practitioner: How professionals think in action. New York: Basic Books. 1983.

52. Lee J, Chan AC, Phillips DR. Diagnostic practise in nursing: a critical review of the literature. Nurs Health Sci 2006;8:57-65.

53. Benner P, Tanner C. Clinical judgment: how expert nurses use intuition. Am J Nurs 1987;87:23-31.

54. Grossman SC, Wheeler K. Predicting patients' deterioration and recovery. Clin Nurs Res 1997;6:45-58.

55. McCutcheon HHI. Intuition: an important tool in the practice of nursing. Journal-of-Advanced-Nursing 2001;35:342-8. 
56. King L, Appleton JV. Intuition: a critical review of the research and rhetoric. J Adv Nurs 1997;26: 194-202.

57. Hamm R.M. Clinical intuition and clinical analysis: Expertise and the Cognitive Continuum. In: Dowie J, Elstein A, editors. Professional judgement. A reader in clinical decision making.Cambridge: Cambridge University Press. 1988:78-104.

58. Welsh I. Evidence-based care and the case for intuition and tacit knowledge in clinical assessment and decision making in mental health nursing practice: an empirical contribution to the debate. Journalof-Psychiatric-and-Mental-Health-Nursing 2001;8:299-305.

59. Chapman GB, Sonnenberg F. Decision making in health care: theory, psychology, and applications. New York: Cambridge University Press. 2000.

60. Sackett DL, Haynes RB, Guyatt GH, Tugwell P. Clinical epidemiology: a basic science for clinical medicine. 2 ed. Boston: Little, Brown. 1991.

61. Richardson WS, Wilson MC, Guyatt GH, Cook DJ, Nishikawa J. Users' guides to the medical literature: $X V$. How to use an article about disease probability for differential diagnosis. Evidence-Based Medicine Working Group. JAMA 1999;281:1214-9.

62. Pauker SG, Kassirer JP. The threshold approach to clinical decision making. N Engl J Med 1980;302:1109-17.

63. Elstein AS. Heuristics and biases: selected errors in clinical reasoning. Acad Med 1999;74:791-4.

64. Kuhn GJ. Diagnostic errors. Acad Emerg Med 2002;9:740-50.

65. Klein JG. Five pitfalls in decisions about diagnosis and prescribing. BMJ 2005;330:781-3.

66. Croskerry P. The importance of cognitive errors in diagnosis and strategies to minimize them. Acad Med 2003;78:775-80.

67. Hashem A, Chi MTH, Friedman CP. Medical errors as a result of specialization. J Biomed Inform 2003;36:61-9.

68. Van Leeuwen YD, Mol SS, Pollemans MC, Drop MJ, Grol R, Van der Vleuten CP. Change in knowledge of general practitioners during their professional careers. Fam Pract 1995;12:313-7.

69. Eva KW. The aging physician: changes in cognitive processing and their impact on medical practice. Acad Med 2002;77(10 Suppl):S1-S6.

70. Kleinmuntz B. Why we still use our heads instead of formulas: Toward an integrative approach. Psychological Bulletin 1990;107:296-310.

71. Gill CJ, Sabin L, Schmid CH. Why clinicians are natural bayesians. BMJ 2005;330:1080-3.

72. Steurer J, Fischer JE, Bachmann LM, Koller M, Ter Riet G. Communicating accuracy of tests to general practitioners: a controlled study. BMJ 2002;324:824-6.

73. Berwick DM, Fineberg HV, Weinstein MC. When doctors meet numbers. Am J Med 1981;71:991-8.

74. Reid MC, Lane DA, Feinstein AR. Academic calculations versus clinical judgments: practicing physicians' use of quantitative measures of test accuracy. Am J Med 1998;104:374-80.

75. Van den Ende J, Van Gompel A, Van den Ende E, Van Damme W, Janssen PA. Bridging the gap between clinicians and clinical epidemiologists: Bayes theorem on an ordinal scale. Theor Surg 1994;9(195).

76. Van den Ende J, Bisoffi Z, Van Puymbroek H, Vanderstuyft P, Van Gompel A, Derese A, Lynen L, Moreira J, Janssen PA. Bridging the gap between clinical practice and diagnostic clinical epidemiology: pilot experiences with a didactic model based on a logarithmic scale. J Eval Clin Pract 2007;13:374-80.

77. Van Puymbroeck H, Remmen R, Denekens J, Scherpbier A, Bisoffi Z, Van den Ende J. Teaching problem solving and decision making in undergraduate medical education: an instructional strategy. Med Teach 2003;25:547-50.

78. Elstein AS. On the origins and development of evidence-based medicine and medical decision making. Inflammation Research 2004;53(Suppl 2):184-9.

79. Sackett DL, Rosenberg WM, Gray JA, Haynes RB, Richardson WS. Evidence based medicine: what it is and what it isn't. BMJ 1996;312:71-2.

80. Haynes RB, Devereaux PJ, Guyatt GH. Clinical expertise in the era of evidence-based medicine and patient choice. ACP J Club 2002;136:A11-A14.

81. Dawes M, Summerskill W, Glasziou P, Cartabellotta A, Martin J, Hopayian K, Porzsolt F, Burls A, Osborne J. Sicily statement on evidence-based practice. BMC Med Educ 2005;5:1.

82. Moulton CA, Regehr G, Mylopoulos M, MacRae HM. Slowing down when you should: a new model of expert judgment. Acad Med 2007;82(10 Suppl):S109-S116. 
83. Stanovich KE, West RF. Individual differences in reasoning: implications for the rationality debate? Behav Brain Sci 2000;23:645-65.

84. Kahneman D. A perspective on judgment and choice: mapping bounded rationality. Am Psychol 2003;58:697-720.

85. Ferreira MB, Garcia-Marques L, Sherman SJ, Sherman JW. Automatic and controlled components of judgment and decision making. J Pers Soc Psychol 2006;91:797-813.

86. Epstein S. Integration of the cognitive and the psychodynamic unconscious. Am Psychol 1994;49: 709-24.

87. Slovic P, Finucane M, Peters E, MacGregor DG. The Affect Heuristic. In: Gilovich T, Griffin D, Kahneman D, editors. Heuristics and biases.New York: Cambridge University Press. 2002:397-420.

88. Finucane $M$, Peters $E$, Slovic $P$. Judgement and decision making: The dance of affect and reason. In: Schneider S.L., Shanteau J, editors. Emerging Perspectives on Judgement and Decision Research.Cambridge, UK: Cambridge University Press. 2003:327-64.

89. Slovic $P$, Finucane $M L$, Peters $E$, MacGregor DG. Risk as analysis and risk as feelings: some thoughts about affect, reason, risk, and rationality. Risk Anal 2004;24:311-22.

90. Damasio AR. Descartes' Error: Emotion, Reason, and the Human Brain. New York: Avon. 1994.

91. Lamond D, Thompson C. Intuition and analysis in decision making and choice. J Nurs Scholarsh 2000;32:411-4.

92. Pretz JE. Intuition versus analysis: strategy and experience in complex everyday problem solving. Mem Cognit 2008;36:554-66.

93. Greenhalgh T. Narrative based medicine: narrative based medicine in an evidence based world. BMJ 1999;318:323-5.

94. Greenhalgh T. Storytelling should be targeted where it is known to have greatest added value. Med Educ 2001;35:818-9.

95. Gaver A, Borkan JM, Weingarten MA. Illness in context and families as teachers: a year-long project for medical students. Acad Med 2005;80:448-51.

96. Macnaughton J. Anecdote in clinical practice. In: Greenhalgh T, Hurwitz B, editors. Narrative based medicine: dialogue and discourse in clininal practice.London: BMJ Publications. 1999:202-11.

97. Eva KW, Hatala RM, Leblanc VR, Brooks LR. Teaching from the clinical reasoning literature: combined reasoning strategies help novice diagnosticians overcome misleading information. Med Educ 2007;41:1152-8.

98. Baarts C, Tulinius C, Reventlow S. Reflexivity-a strategy for a patient-centred approach in general practice. Fam Pract 2000;17:430-4.

99. Mamede S, Schmidt HG. The structure of reflective practice in medicine. Med Educ 2004;38:1302-8.

100. Hjortdahl P. The influence of general practitioners' knowledge about their patients on the clinical decision-making process. Scand J Prim Health Care 1992;10:290-4.

101. Hjortdahl P. Continuity of care. In: Jones R, Britten N, Culpepper L, Gass D.A., Grol R, Mant D, Silagy C, editors. Oxford Textbook of Primary Medical Care. Volume 1 Principles and Concepts.Oxford: Oxford University Press. 2004:249-52.

102. Hani MA, Keller H, Vandenesch J, Sonnichsen AC, Griffiths F, Donner-Banzhoff N. Different from what the textbooks say: how GPs diagnose coronary heart disease. Fam Pract 2007;24:622-7.

103. Jones I, Morrell D. General practitioners' background knowledge of their patients. Fam Pract 1995;12:49-53. 

win

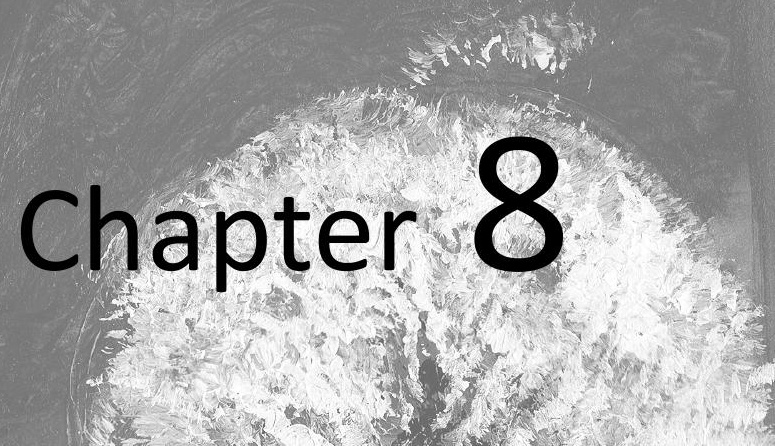

Establishing an international research agenda on gut feelings in general practice using the nominal group

technique
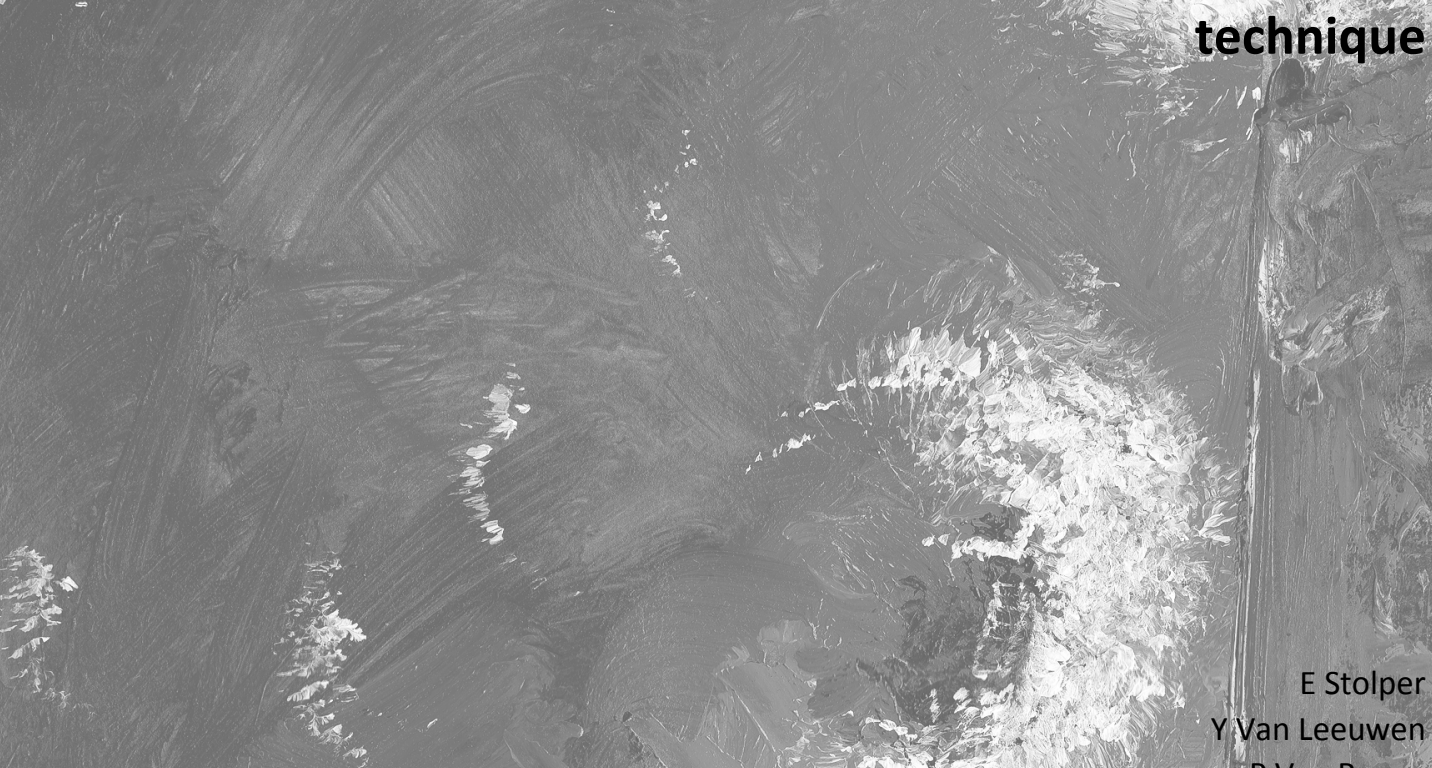


\section{Abstract}

\section{Objective}

Although gut feelings play a substantial role in general practitioners diagnostic reasoning there is little evidence about their diagnostic and prognostic values. Consensus on the two types of gut feelings, a sense of alarm and a sense of reassurance, has enabled us to operationalise the concept. We now need to know which aspects of gut feelings are most relevant to daily practice and medical education and thus need further study. What research questions would enable us to validate the concept of gut feelings and estimate its usefulness for daily practice and medical education?

\section{Methods}

The nominal group technique (NGT) is a qualitative research method of judgmental decision-making involving four phases (generating ideas, recording them, evaluation and group decision). Dutch and Belgian university teachers and researchers whose subject is general practice $(\mathrm{N}=18)$ attended one of three scheduled meetings.

\section{Results}

The three groups produced 20 research questions, regarding the diagnostic value, the validation of determinants, opportunities for integrating gut feelings in medical education, and some other ideas. Appropriate proposed designs included prospective recording, observational designs and experimental studies.

\section{Conclusion}

NGT helped us to establish an international research agenda on gut feelings in general practice which can be used in collaborative research with other countries. 


\section{Introduction}

General practitioners (GPs) sometimes base clinical decisions on gut feelings alone, even though there is little evidence on the diagnostic and prognostic value of such gut feelings in daily practice. Focus group research into gut feelings in general practice has shown that many GPs in the Netherlands trust their gut feelings, which act as a compass steering GPs through busy office hours and enabling them to handle complex problems. ${ }^{1}$ Primary care research into the diagnostic value of signs and symptoms for serious infections in children has identified the physician's feeling that "something is wrong" as the most important diagnostic item. ${ }^{2}$ Conversely, some GPs in our focus groups distrusted their intuitive gut feelings, regarding them as irrational and lacking scientific foundation. We did an e-mail survey among GPs in all countries involved in the European General Practitioners Research Network (EGPRN), asking them whether they recognised our description of the "sense of alarm" and if they had a typical phrase in their language to express this feeling of uneasiness. This survey showed that the sense of alarm is a rather common phenomenon in general practices in Europe. Thus, although gut-feelings are generally recognised as a frequently used but poorly understood diagnostic tool, research into its validity seems a neglected area. A study of the descriptions of two types of gut feeling, a sense of alarm and a sense of reassurance, led to a consensus (see Text box 8.1). ${ }^{3}$ These descriptions may enable researchers to operationalise the concept of gut feelings, making them in some way measurable. However, before initiating further research we need to know which questions are most relevant for daily practice and medical education and - perhaps more important and more difficult - which research designs are appropriate and feasible. Academic experts on general practice, appointed for educational or research tasks, can help us in defining and prioritising the questions.

Text box 8.1 Consensus on gut feelings.

- Statement 1a: A 'sense of alarm' means that a GP perceives an uneasy feeling as he/she is concerned about a possible adverse outcome.

- Statement 3: A 'sense of alarm' implies that a GP worries about a patient's health status, even though he/she has found no specific indications yet; it is a sense of 'there's something wrong here'.

- Statement 2: A 'sense of alarm' activates the diagnostic process by stimulating a GP to formulate and weigh up working hypotheses that might involve a serious outcome.

- Statement 4: A 'sense of alarm' means that, if possible, the GP needs to initiate specific management to prevent serious health problems

- Statement 9: A 'sense of alarm' will decrease as the diagnosis and the right management become clearer.

- Statement 5: A 'sense of reassurance' means that a GP feels secure about the further management and course of a patient's problem, even though he/she may not be certain about the diagnosis: everything fits in.

- Statement 8: The 'sense of reassurance' and the 'sense of alarm' constitute a dynamic element in a GP's diagnostic process. 
This article describes the development of an international research agenda including research questions that aim to validate the concept of gut feelings and estimate its value for daily practice and medical education.

\section{Methods}

We used the nominal group technique (NGT) because the study of this topic is conceptually complex and intricate and there are no guiding examples of research in the literature. NGT involves four phases: generating ideas, recording them, evaluation and a group decision phase. The technique enables researchers to gather information from relevant experts. ${ }^{4,5}$ It facilitates creative problem solving by means of judgmental decision making ${ }^{6-8}$ in situations where routine answers are inadequate. This means that the judgments of experts on the topic are integrated, in our case to establish a research agenda.

We purposively sampled well-known opinion leaders and experts on general practice in the Netherlands and Belgium, who were working at universities in educational or research programmes about general practice. We approached 30 colleagues by phone, 27 of whom were willing to cooperate and received written information about the goal of the meeting and the procedure. These 27 colleagues were familiar with our research subject, since they had also been involved in an earlier study that aimed to achieve consensus on definitions of gut feelings. ${ }^{3}$ We invited them to attend one of the three regionally organised meetings, and 18 accepted our invitation (6, 5 and 7 per meeting). Reasons to decline included prior engagements and illness. No financial compensation was given. The sessions were chaired by experienced and independent moderators, assisted by one of the authors (MVdW, PVR, GJD) using flip-charts. We developed a scenario for the meetings in advance to ensure that all phases of NGT would be completed.

In the first phase, that of "generating ideas", the moderator explained the procedure and asked the participants to write down in silence, what they regarded as the main research questions relating to gut feelings, as well as appropriate designs for such research. Stimulated by the written information they had received about the aim of the meeting and the method that will be used, some of the experts had already formed specific ideas in their mind. In the second phase, "recording", the members of the group were engaged in a round-robin feedback session to concisely record each idea. Research questions and designs were noted and numbered on flip-charts (6-8 in each session). In the third phase, "evaluation", each recorded idea was clarified and evaluated by discussion, in which those present proposed and weighed the arguments for and against the proposed questions and designs. The purpose of the fourth and final phase was to aggregate the judgments of individual members, in order to determine the relative importance of the research questions and the corresponding designs. In this phase, the experts voted individually to prioritise the ideas, and their 
votes were used to arrive at a group decision. Each member selected five research questions and the corresponding designs and wrote the numbers down on separate cards, starting with the most important idea and ending with the least important one. The numbers on the cards were noted on a flip-chart and an overall prioritised list was drawn up. Afterwards, a brief discussion was held to evaluate the procedure and the outcome: no objections were made.

\section{Results}

The three groups produced 20 research questions with corresponding appropriate designs. Although there was considerable overlap in the results and ideas were sometimes difficult to distinguish, the second session produced 5 new questions and 6 new or modified designs compared to the first one and even the third session resulted in 3 new research questions and 2 new or modified designs. After the three meetings we compared all research questions and corresponding designs and distinguished 10 main research questions (Text box 8.2) and 9 designs (Text box 8.3). They were related to 4 topics: the diagnostic value of gut feelings, the validation of determinants such as contextual information and the GP's experience, the possibilities for including gut feelings in medical eduation, and some other ideas.

Text box 8.2 Research questions.

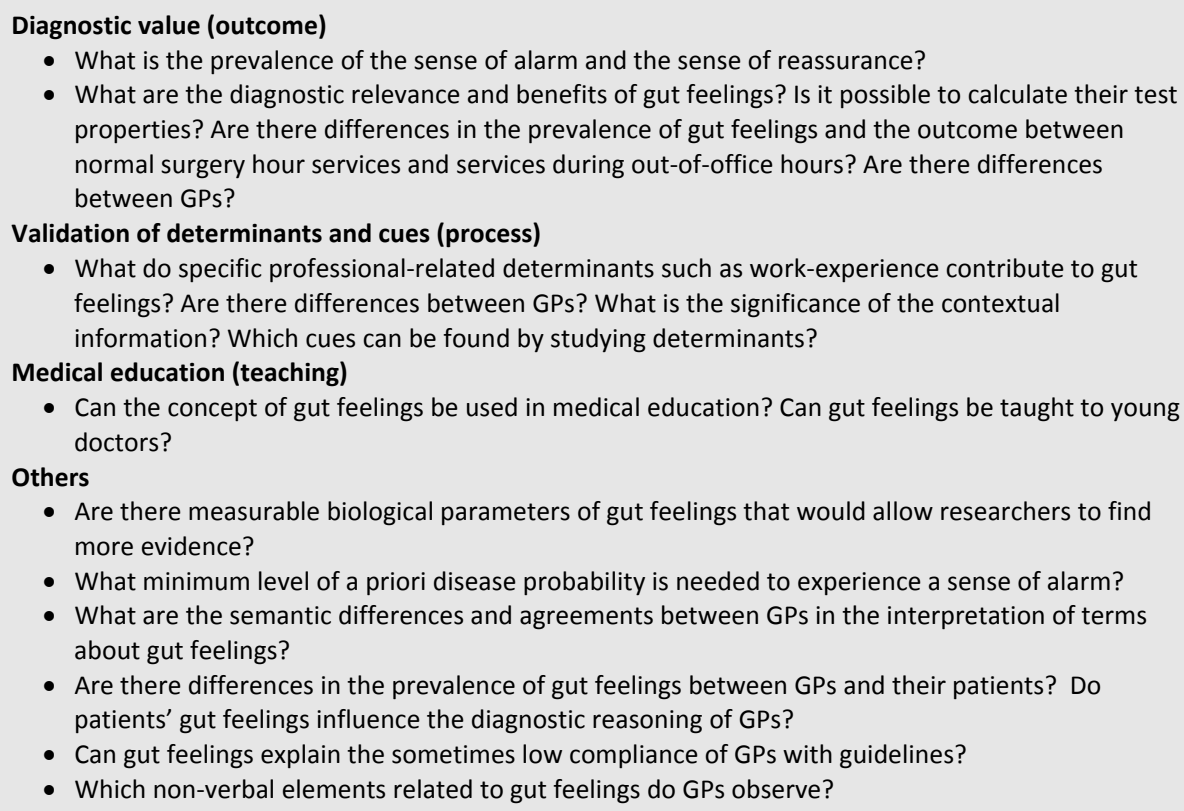

- What are the diagnostic relevance and benefits of gut feelings? Is it possible to calculate their test properties? Are there differences in the prevalence of gut feelings and the outcome between normal surgery hour services and services during out-of-office hours? Are there differences between GPs?

Validation of determinants and cues (process)

- What do specific professional-related determinants such as work-experience contribute to gut feelings? Are there differences between GPs? What is the significance of the contextual information? Which cues can be found by studying determinants?

Medical education (teaching)

- Can the concept of gut feelings be used in medical education? Can gut feelings be taught to young doctors?

Others

- Are there measurable biological parameters of gut feelings that would allow researchers to find more evidence?

- What minimum level of a priori disease probability is needed to experience a sense of alarm?

- What are the semantic differences and agreements between GPs in the interpretation of terms about gut feelings?

- Are there differences in the prevalence of gut feelings between GPs and their patients? Do patients' gut feelings influence the diagnostic reasoning of GPs?

- Can gut feelings explain the sometimes low compliance of GPs with guidelines?

- Which non-verbal elements related to gut feelings do GPs observe? 
Text box 8.3 Corresponding appropriate designs.

\section{Diagnostic value}

- Recording gut feelings, determinants, expected outcome (ICPC), in surgery and out of office hours. Follow-up after three months. Problem: which reference standard?

Valdation of determinants and cues. Medical education

- Stimulated recall after surgery: selection of patients on the basis of a strong sense of alarm; reflection on determinants afterwards.

- Stimulated recall by experienced GPs and trainees after encounters with simulation patients. Same design but after observing video tapes with real patients.

- Studies based on vignettes.

- Experimental study with an intervention in the form of a short course to make participants aware of gut feelings and their significance involving students, inexperienced GPs and experienced GPs.

- Experimental study with an intervention in the form of reflection after each consultation; recording gut feelings and determinants.

- Giving trainees an opportunity to tell their consultation stories and analyse the role of gut feelings.

Others

- Conversation analysis or linguistic analysis of transcripts of consultations.

- Recording heart rate and skin resistance during office hours with simulation patients or during observations of video-taped consultations.

After each meeting, the exact order of the research questions of each group was calculated with the Kruskal-Wallis test (because of the ordinal distribution), but the results hardly differ from the assessments at the end of the last phase. (see Table 8.1) The results of the three groups were not entirely comparable since each group produced a number of unique ideas. Therefore, the ranking of all research questions with corresponding designs after the three meetings was impossible. 
Table 8.1 Ratings per group, of all research questions and corresponding appropriate designs (1=highest rating in a group).

\begin{tabular}{|c|c|c|c|c|c|c|}
\hline \multirow[b]{2}{*}{ Rating } & \multicolumn{2}{|l|}{ Ratings of group a } & \multicolumn{2}{|l|}{ Ratings of group b } & \multicolumn{2}{|l|}{ Ratings of group c } \\
\hline & Aim & Design & Aim & Design & Aim & Design \\
\hline 1 & $\begin{array}{l}\text { Validation of } \\
\text { determinants and } \\
\text { cues }\end{array}$ & Recording & $\begin{array}{l}\text { Diagnostic value } \\
\text { Prevalence, } \\
\text { relevance, } \\
\text { testproperties. }\end{array}$ & $\begin{array}{l}\text { Recording, } \\
\text { follow-up }\end{array}$ & $\begin{array}{l}\text { Diagnostic value } \\
\text { Prevalence, } \\
\text { relevance, } \\
\text { testproperties. }\end{array}$ & $\begin{array}{l}\text { Recording, } \\
\text { follow-up }\end{array}$ \\
\hline \multirow[t]{2}{*}{2} & \multirow{2}{*}{$\begin{array}{l}\text { Diagnostic value } \\
\text { Prevalence, } \\
\text { relevance, } \\
\text { testproperties }\end{array}$} & $\begin{array}{l}\text { Reflection after } \\
\text { consultation }\end{array}$ & \multirow{2}{*}{$\begin{array}{l}\text { Validation of } \\
\text { determinants and } \\
\text { cues } \\
\text { Interdoctor } \\
\text { variation }\end{array}$} & \multirow[t]{2}{*}{$(-)$} & \multirow{2}{*}{$\begin{array}{l}\text { Validation of } \\
\text { determinants and } \\
\text { cues }\end{array}$} & $\begin{array}{l}\text { Video } \\
\text { stimulated recall }\end{array}$ \\
\hline & & $\begin{array}{l}\text { Recording, } \\
\text { follow-up }\end{array}$ & & & & Video recording \\
\hline 3 & $\begin{array}{l}\text { Others } \\
\text { Finding cut off } \\
\text { points }\end{array}$ & $\begin{array}{l}\text { Manipulation in } \\
\text { vignette studies }\end{array}$ & $\begin{array}{l}\text { Others } \\
\text { Biological variables }\end{array}$ & $\begin{array}{l}\text { Measuring } \\
\text { heart rate and } \\
\text { skin resistance }\end{array}$ & $\begin{array}{l}\text { Setting as a } \\
\text { determinant }\end{array}$ & $\begin{array}{l}\text { Surgery vs out- } \\
\text { of- office } \\
\text { Acute vs chronic }\end{array}$ \\
\hline 4 & $\begin{array}{l}\text { Validation of } \\
\text { determinants and } \\
\text { cues }\end{array}$ & $\begin{array}{l}\text { Analysis of cases } \\
\text { after consultation }\end{array}$ & $\begin{array}{l}\text { Validation of } \\
\text { determinants and } \\
\text { cues } \\
\text { Setting as a } \\
\text { determinant }\end{array}$ & $\begin{array}{l}\text { Surgery vs out- } \\
\text { of- office } \\
\text { Acute vs } \\
\text { chronic }\end{array}$ & $\begin{array}{l}\text { Other } \\
\text { determinants }\end{array}$ & $\begin{array}{l}\text { Case vignettes } \\
\text { study }\end{array}$ \\
\hline 5 & \begin{tabular}{|l} 
Others \\
Interdoctor \\
variation
\end{tabular} & Stimulated recall & $\begin{array}{l}\text { Others } \\
\text { Non-verbal } \\
\text { elements }\end{array}$ & $(-)$ & \begin{tabular}{|l} 
Others \\
Doctor-patient \\
differences
\end{tabular} & $(-)$ \\
\hline 6 & & & $\begin{array}{l}\text { Validation of } \\
\text { determinants and } \\
\text { cues } \\
\text { Expertise }\end{array}$ & $\begin{array}{l}\text { Comparing } \\
\text { experts and } \\
\text { trainees, video } \\
\text { observation } \\
\end{array}$ & $\begin{array}{l}\text { Influence on } \\
\text { guideline } \\
\text { compliance }\end{array}$ & $(-)$ \\
\hline 7 & & & $\begin{array}{l}\text { Others } \\
\text { Semantic } \\
\text { differences in } \\
\text { interpretation }\end{array}$ & $\begin{array}{l}\text { Linguistic } \\
\text { analyses }\end{array}$ & $\begin{array}{l}\text { Validation of } \\
\text { determinants and } \\
\text { cues }\end{array}$ & $\begin{array}{l}\text { Conversation } \\
\text { analysis }\end{array}$ \\
\hline \multirow[t]{2}{*}{8} & & & \multirow[t]{2}{*}{ Medical education } & $\begin{array}{l}\text { Trainees telling } \\
\text { their stories }\end{array}$ & & \\
\hline & & & & Studying videos & & \\
\hline
\end{tabular}

\section{Discussion}

With the help of NGT we were able to establish a research agenda on gut feelings in general practice. We listed 10 main research questions and 9 corresponding appropriate designs. These results allow us to start high-quality studies into the validity of this generally recognised but poorly researched diagnostic tool, and into the possibilities for integrating it in medical education.

The highest priority was given to the questions about the prevalence of gut feelings and their diagnostic accuracy. Gut feelings can function as a compass in uncertain and complex situations which are a characteristic part of a doctor's life ${ }^{1,9,10}$, but do they contribute to correct decisions? Although the question about the test properties of this diagnostic tool thus seems justified measuring them will not be easy, since the 
sense of alarm does not occur very frequently during surgery hours. Although this problem could be overcome by using vignette and video tape studies, they lack the contextual information of daily practice, which is important for recognising pattern discrepancies.

A number of further topics could be studied. Indeed, it would be important to study the contributions of the most important determinants because they can create possibilities to use these determinants in medical education and postgraduate training. Another possible research topic is how students can be trained to recognise this tool or general practitioners to improve its diagnostic value in daily practice, while avoiding pitfalls. Do experienced GPs differ from students in their observation and selection of patient- and disease-related cues? And can any evidence be found in the literature to justify these cues? Some specific patient related cues may only be recognised by the patient's own practitioner. Patients themselves or their caregivers have gut feelings too and it would be interesting to study the extent to which a patient's gut feeling influence the doctor's decision-making process. Indeed, it may be worth while taking patients' gut feelings seriously when they say that something is wrong.

NGT has rarely been used as a method to generate ideas for study designs, as a search in PubMed showed (searched for "Group Processes"[Mesh] OR "Consensus"[Mesh] OR "Consensus Development Conferences"[Mesh] AND "Research"[Mesh] OR "Research Design"[Mesh] AND Nominal OR Agenda). ${ }^{11-13}$ Nevertheless, it seemed to be an efficient technique to gather specific ideas about difficult research questions and corresponding appropriate designs. The benefit of NGT is that all experts get equal opportunity to participate and to influence the decisions since it reduces the conforming common influence that tends to occur in face-to-face group meetings. ${ }^{5,6}$ Using consecutive groups seems worthwhile since each new group also contributed new ideas.

\section{Conclusions}

An extensive international research agenda on gut feelings has been established with the help of NGT. We propose to use this agenda in collaborative research with other European countries to further validate the concept of gut feelings. 


\section{References}

1. Stolper CF, Van Bokhoven MA, Houben PHH, Van Royen P, Van de Wiel M, Van der Weijden T, Dinant GJ. The diagnostic role of gut feelings in general practice. A focus group study of the concept and its determinants. BMC Fam Pract 2009;10:17.

2. Van den Bruel A. The value of signs and symptoms for the diagnosis of serious infections in children in primary care. Catholic University Leuven Belgium. 2006.

3. Stolper CF, Van Royen P, Van Bokhoven MA, Houben PHH, Van de Wiel M, Van der Weijden T, Dinant GJ. Consensus on gut feelings in general practice. BMC Fam Pract 2009;10:66.

4. Jones J, Hunter D. Consensus methods for medical and health services research. BMJ 1995;311: 376-80.

5. Gallagher M, Hares T, Spencer J, Bradshaw C, Webb I. The nominal group technique: a research tool for general practice? Fam Pract 1993;10:76-81.

6. Dunham RB. Nominal Group Technique: a users' guide. Organizational Behavior 1998.

7. Bazan S. Enhancing decision-making effectiveness in problem-solving teams. Clin Lab Manage Rev 1998;12:272-6.

8. Carney O, McIntosh J, Worth A. The use of the Nominal Group Technique in research with community nurses. J Adv Nurs 1996;23:1024-9.

9. Griffiths F, Green E, Tsouroufli M. The nature of medical evidence and its inherent uncertainty for the clinical consultation: qualitative study. BMJ 2005;330:511.

10. Dinant GJ. Diagnosis and decision. Undifferentiated illness and uncertainty in diagnosis and management. In: Jones R, Britten N, Gulpepper L, Gass D, Grol R, Mant D, Silagy C, editors. Oxford Textbook of Primary Medical Care.Oxford: Oxford University Press. 2004:201-3.

11. Broder MS, Landow WJ, Goodwin SC, Brook RH, Sherbourne CD, Harris K. An agenda for research into uterine artery embolization: results of an expert panel conference. J Vasc Interv Radiol 2000;11: 509-15.

12. Kramer JM. Managing the risks of therapeutic products: proceedings of a workshop. Pharmacoepidemiol Drug Saf 2005;14:619-28.

13. Mootz RD, Hansen DT, Breen A, Killinger LZ, Nelson C. Health services research related to chiropractic: review and recommendations for research prioritization by the chiropractic profession. J Manipulative Physiol Ther 2006;29:707-25. 


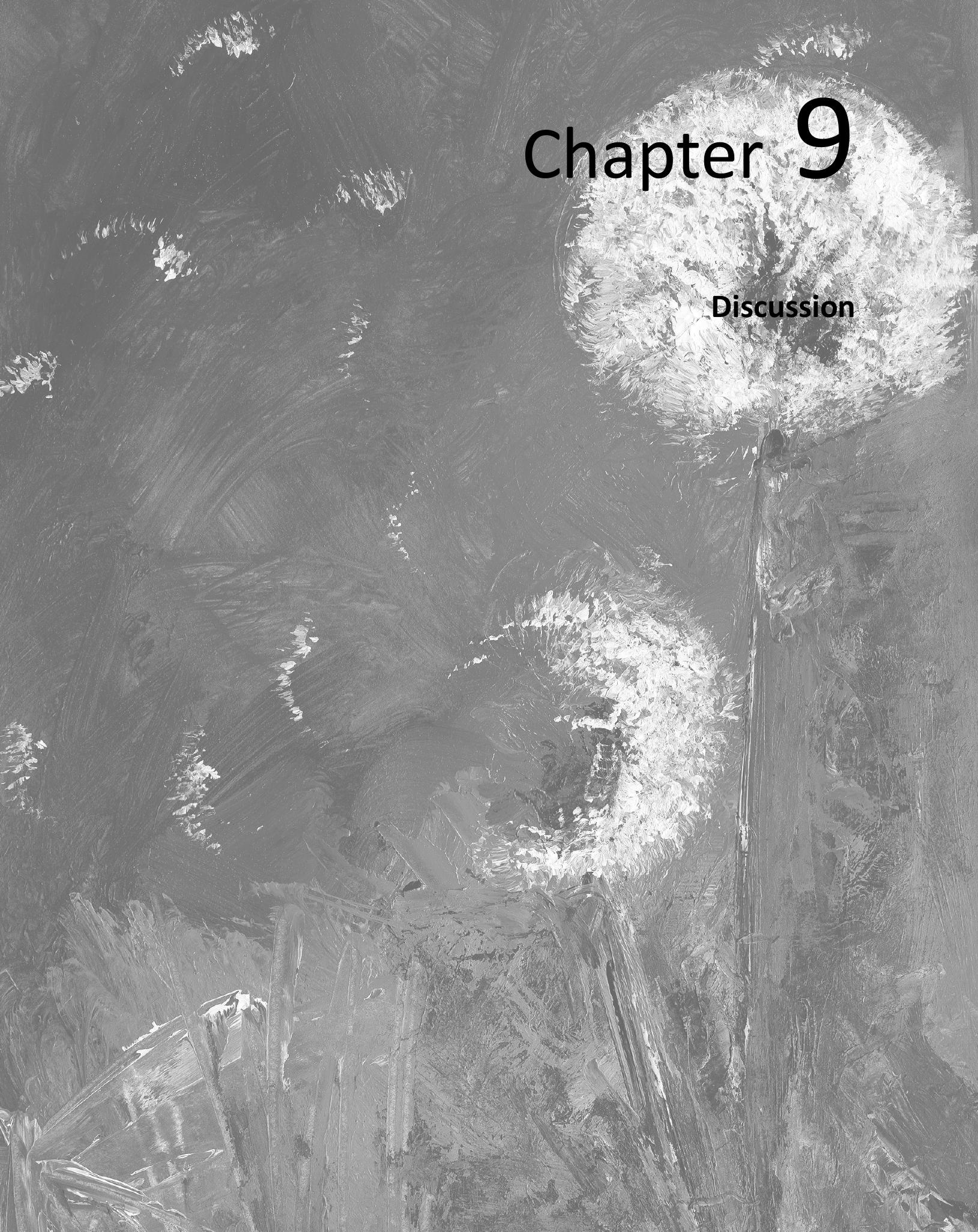

$x$ 
112 Chapter 9 


\section{General discussion}

\section{Main findings}

Reviewing the results of our study in the light of our research questions, we found clear answers: gut feelings play a substantial role in general practitioners' (GPs) diagnostic reasoning process in the Netherlands and Flanders - probably also in the rest of Europe - as they stimulate diagnostic reasoning; disciplinary tribunals in the Netherlands have acknowledged this role; consensus has been reached on statements about gut feelings; major determinants of gut feelings, like experience and contextual information, have been identified, and we now have a better understanding of how gut feelings arise and influence GPs' diagnostic reasoning. According to GPs, gut feelings are useful in the sometimes unclear and complex diagnostic situations encountered in general practice, where they have to judge in conditions of uncertainty. An extensive research agenda has been established which can be used in collaborative international research.

However, we have not yet realized our dream to construct a four-field table with numbers in all boxes which would allow us to calculate the predictive values and likelihood ratios of gut feelings. So far, we have mostly used qualitative methods to get a grip on the phenomenon of gut feelings. From here on, we can start designing an instrument to measure gut feelings, which is one of the most urgent topics on our research agenda, so we can gradually merge primarily qualitative with more quantitative research.

\section{Strengths and weaknesses of our study}

Our study was the first in the domain of general practice to extensively investigate the role of gut feelings in the diagnostic reasoning of GPs. This is remarkable, since GPs all over Europe seem to recognize that gut feelings may play a substantial part in the diagnostic process, though gut feelings are sometimes considered as non-scientific and an unreliable source of knowledge. Although it is not easy to get a grip on gut feelings, the qualitative approach we used yielded highly valid information within a short time. We used a grounded theory approach involving focus groups and a Delphi consensus procedure to study the research question, i.e. the meaning and definition of gut feelings, from different points of view (methodological triangulation), and managed to formulate, for the first time in the literature, an extended description of gut feelings, including their major potential determinants. We also gained a clear understanding of the substantial role of gut feelings in the GPs' diagnostic reasoning process. Our results are supported by the literature on diagnostic reasoning as well as by psychological theories of dual processing. Our conclusion that gut feelings play an important part in general practice is confirmed by the way disciplinary tribunals in the Netherlands have dealt with the sense of alarm. Last but not least, presentations of our results at international fora of GP researchers have led to the foundation of an 
international expert group as a platform where research findings and methodological expertise can be shared and cross-border projects initiated (see below). The results of comparable research in Germany and France have confirmed our concept of gut feelings.

One of our future challenges will be to use quantitative methods to obtain more data about the significance of gut feelings in diagnostic reasoning, as the lack of such quantitative data may be seen as a weakness of our study. However, our qualitative research results are indispensible in preparing for quantitative research.

\section{Medical education}

During our investigations of the last few years, we became increasingly aware of the complexity of the diagnostic reasoning process. Although it is understandable that research on this process has been split up into several - historically developed and sometimes strictly separated - approaches, the integrated view of the entire process may have been lost in some educational programmes. ${ }^{1,2}$ As they gain more experience, GPs become experts at dealing with different sources of information and at integrating various simultaneous diagnostic tracks. Biomedical, evidence-based, experience-based and psychological knowledge, as well as contextual information, clinical skills, guidelines and gut feelings, all contribute in their own way to the continuing process in which GPs have to select, weigh up, integrate, decide and evaluate information. Analytical and non-analytical processes interact to play a key role in the diagnostic process. Ways have to be found to teach these different strategies in an integrated manner.

An example of an educational approach combining these strategies has been developed in Belgium. In this approach, a sense of alarm relating to a specific sign or symptom is the start of a diagnostic reasoning process. ${ }^{3-6}$ Students have to visualize a diagnostic panorama representing a differential diagnosis. They learn to estimate, often intuitively, the clinical weight of the other presenting signs, symptoms and laboratory results, using five categories of discriminative powers from "useless" to "very strong" which represent classes of log10LRs. With the help of a table, the pretest probability can be estimated in classes corresponding to rounded log10 pre-test odds. This allows the physicians to add the power of an argument like a symptom, a sign or a laboratory result to the rounded pre-test log10 odds to calculate the post-test probability. Since physicians usually add instead of multiplying when they use Bayesian rule, ${ }^{7}$ this mode of diagnostic reasoning fits in well with daily practice. Bayesian rule, epidemiological data, intuitive knowledge and decision thresholds are combined in a reasoning process that leads to confirmation or rejection of diagnostic hypotheses. The effect of such educational approaches on the diagnostic reasoning of GPs in clinical practice should be further explored. 


\section{Science and art, or ratio and affect}

\section{Science and art}

Some GPs in our focus groups distrusted their subjective gut feelings, as they felt these did not fit into the scientific attitude that is thought to be required of GPs. Their view corresponds well with the twin concepts of "science" and "art", i.e. the hard objective core of the scientific attitude of physicians and the soft subjective "periphery" of their work. However, is this distinction correct? Are GPs first and foremost scientists, who base their work on scientific methods and insights?

Gerrit Glas argues for the distinction between clinical knowledge, scientific knowledge and everyday knowledge. ${ }^{8,9}$ He distinguishes four knowledge types (or levels) with increasing degrees of abstraction that are involved in diagnostic reasoning: the everyday experience of signs and symptoms, clinical knowledge as exemplified in diagnostic judgement and tailor-made therapeutic expertise, scientific biomedical knowledge and implicit philosophical knowledge. GPs use and have to bridge the first three types of knowledge and, in doing so, implicitly address to larger epistemological issues related to their discipline (the final level, which we will not deal with here). ${ }^{10}$

Diagnostic reasoning implies a transformation of the patient's individual story into a clinically recognizable pattern of signs and symptoms by applying general scientific knowledge to the individual case. This process of identification and selection of relevant signs and symptoms is guided by more than abstract and general scientific knowledge alone: it also involves specific features of the presentation by the patient and contextual knowledge like biographical details, family history, medical history etc. The basic distinction between clinical and scientific knowledge lies in the fact that scientists aim to discover general patterns and laws, whereas clinicians are focused on individual cases and specific relationships between general patterns. ${ }^{11}$

These individual, contextual and temporal dimensions of clinical reasoning inevitably lead to a certain degree of diagnostic uncertainty. Signs and symptoms are weighed up against the background of the individual situation and evaluated in the time. People vary and diseases manifest themselves in different ways and in different stages of development. Scientific evidence underlying guidelines is often lacking ${ }^{12,13}$ and biomedical knowledge changes with time, ${ }^{14}$ and even with place or context. ${ }^{15,16} \mathrm{~A}$ diagnosis is very useful, since it offers some degree of certainty and may indicate therapeutic options, but it is often still a provisional and individual interpretation of particular signs and symptoms. GPs are neither scientists nor artists, but it is inherent in their profession to work with the complex and often uncertain types of knowledge and their mutual relationships. ${ }^{17}$ 


\section{Ratio and affect}

A closely related question regards the role of affect (or emotion), or more specifically, the relation between affect and rationality in decision-making. According to many great theorists, emotion must be curbed to strengthen reason, and there is indeed evidence in the literature that emotions sometimes impede sound judgements or skew them. Nevertheless, in spite of these age-old philosophical and common-sense judgements, empirical evidence in neuroscience supports the view that only a fruitful combination and interaction of ratio and affect leads to a sound and balanced judgement. Based on neuropsychological and imaging studies of patients with specific brain damage, Antonio Damasio emphasized the role of emotion-inducing brain centres in the reasoning process. ${ }^{18,19}$ Emotions are physical reactions which are experienced as feelings that arise before conscious reasoning, and influence it. People with a full capacity of analytical reasoning but with damaged emotion-inducing centres lack the affective sensitivity to select relevant information, to recognize what problems should be addressed and what solutions would be better, and to make decisions. ${ }^{20}$ Damasio introduced the hypothesis of the somatic marker. ${ }^{18}$ The prefrontal cortex represents our experiences in the past, which are stored as dispositional representations of bodily states that are associated with memories of situations of a certain type. These representations, when activated, may trigger emotion-inducing centers. ${ }^{19}$ When we are faced with situations from the past which are associated with favourable or unpleasant feelings, an emotional reaction is triggered by the prefrontal cortex and experienced in the body. This largely unconscious emotional response functions as a somatic marker, a sense of alarm or a sense of reassurance, like a gut feeling, and appears before any conscious thought.

Metaphorically speaking, one might consider ratio as the rudder of a ship sailing on the ocean, coping with ever changing winds and currents. ${ }^{20}$ Affect provides the sails; it makes the ship leave the harbour and carries it forward. Without a rudder, the ship will never steer a straight course to reach its destination in the face of opposing winds and currents, but without sails the ship will not even leave the harbour. The rudder identifies all courses for different destinations, but the affective drive to make a choice and to get the ship in motion is absent. Working together, rudder and sails will enable the ship to navigate the high seas to far-off destinations.

Medical education should therefore integrate reason and affect, enhancing the positive effects of emotion and reducing undesirable effects. ${ }^{20}$ 


\section{Final recommendations and planned activities}

\section{Training non-analytical diagnostic reasoning}

Most GPs in our focus groups believed that gut feelings can be taught, though they are not easily learned (chapter 4). Indeed, the practical part of the general practice training curriculum in the Netherlands creates a learning environment that offers some room for non-analytical aspects, according to GP trainers in the focus groups. They said that reflection could be a way to develop or become aware of gut feelings. However, the formal curriculum in the Netherlands seems to offer little opportunity to train non-analytical reasoning as an integral part of diagnostic reasoning, and it is unknown whether such skills are systematically trained, what methods are used and what effects they have. ${ }^{21-25}$ The objectives of research into this educational field may be to investigate how non-analytical aspects of diagnostic reasoning are in some way incorporated in general practice training programmes and to identify obvious gaps and design ways to fill them. The ultimate aim of this research would be to improve the quality of GP training programmes in order to strengthen the diagnostic competence of young GPs. This can be achieved by using a mixture of qualitative and quantitative research methods.

\section{Measuring the diagnostic value of gut feelings}

More research is also needed to validate the consensus statements that resulted from our study. Validation in this sense is a process of testing a hypothesis with the help of a reference standard or a valid scale to achieve an objective score, but such a scale is currently unavailable. The concept of construct validity probably offers a solution. ${ }^{26} \mathrm{~A}$ construct can be thought of as a theory to explain relations between observed phenomena, in this case between GPs' gut feelings and the occurrence of serious disease in patients. Construct validation would then be an on-going process of comparing theories with the accuracy of predictions of the occurrence of serious disease in a patient based on the GP's gut feeling, and adjusting theories and measurement instruments, like a short questionnaire based on the consensus statements. ${ }^{26}$

Manipulating information in the case vignettes that we plan to construct for this purpose will also enable us to study the contribution of various determinants of gut feelings to the outcome. One disadvantage of this vignette approach is the lack of contextual knowledge, which may be a major determinant of gut feelings in general practice. The next step should therefore be to examine the significance of contextual knowledge $^{27}$, experience and the other determinants of gut feelings in actual practice among patients presenting real symptoms, by comparing experienced and less experienced GPs in their own practice or during out-of-office hours (the latter representing a situation without the benefit of contextual knowledge). This would then finally allow us to investigate the diagnostic work-up of a sense of alarm or a 
sense of reassurance and assess their predictive values, enabling us to answer the questions with which we once started.

\section{Collaborative research}

The scope of the research agenda is wide, and realizing all ideas will require a collaborative approach. In Germany, the sense of alarm ("Alarmgefühl") has been studied several years ago by means of in-depth interviews with nine GPs, resulting in a description of the sense of alarm as well as its triggers and causes and the conditions that favour it. ${ }^{28}$ A comparison of these results with our findings shows many similarities. In France, a Delphi consensus procedure with a heterogeneous sample of 34 GPs involved in university educational or research programmes, has been carried out to validate our findings. ${ }^{29}$ The French researchers took as their starting point the six statements we formulated after the focus group research. The results of their Delphi consensus procedure were highly comparable to those obtained by us in a similar procedure. In general, the concept of gut feelings as described after our focus group research has been confirmed by the results of the studies in Germany and France.

Meanwhile, support by the European General Practice Research Network (EGPRN) has allowed an international expert group - the European Expert Group on Cognitive and Interactive Processes in Diagnosis and Management in General Practice or CogitaProDiaman for short - to be successfully established (www.gutfeelings ingeneralpractice. eu). CogitaProDiaman will help us to organize meetings to share research findings and methodological expertise and prepare international research proposals for cross-border projects. One of the goals is to advise other researchers in Europe on how to set up new research into gut feelings, while another is to present the group and its research findings at international scientific research fora like EGPRN and WONCA. 


\section{References}

1. Norman GR. The epistemology of clinical reasoning: perspectives from philosophy, psychology, and neuroscience. Acad Med 2000;75(10 Suppl):S127-S135.

2. Elstein AS. Clinical problem solving and decision psychology: comment on "the epistemology of clinical reasoning". Acad Med 2000;75(10 Suppl):S134-S136.

3. Van Puymbroeck H, De Wachter J, Blanckaert F, Boeckx J, Bruyninckx R, Ferrant L, Debaene L, Van den Ende J. Clinical logic (part 1) From presenting complaint to diagnostic landscape [Klinische Logica (deel 1). Van aanmeldingsklacht tot diagnostisch landschap]. Huisarts Nu 2004;33:123-8.

4. Moreira J, Bisoffi Z, Narvaez A, Van den Ende J. Bayesian clinical reasoning: does intuitive estimation of likelihood ratios on an ordinal scale outperform estimation of sensitivities and specificities? J Eval Clin Pract 2008;14:934-40.

5. Van Puymbroeck H, Boeckx J, Blanckaert F, Bruyninckx R, Debaene L, De Wachter J, Ferrant L, Van den Ende J. Clinical Logic (part 2) From diagnostic landscape to diagnosis [Klinische logica (deel 2). Van diagnostisch landschap tot diagnose]. Huisarts Nu 2004;33:201-14.

6. Van den Ende J, Bisoffi Z, Van Puymbroek H, Vanderstuyft P, Van Gompel A, Derese A, Lynen L, Moreira J, Janssen PA. Bridging the gap between clinical practice and diagnostic clinical epidemiology: pilot experiences with a didactic model based on a logarithmic scale. J Eval Clin Pract 2007;13:374-80.

7. Van den Ende J, Van Gompel A, Van den Ende E, Van Damme W, Janssen PA. Bridging the gap between clinicians and clinical epidemiologists: Bayes theorem on an ordinal scale. Theor Surg 1994;9(195).

8. Glas G. Clinical Practice and the Complexity of Medical Knowledge. European Philosophy of Medicine and Health Care 1995;3(3).

9. Glas G. Ethical norms and the role of scientific knowledge in the relation between doctor and patient [Normativiteit en de rol van wetenschappelijke kennis in de arts-patient relatie]. In: Jochemsen $\mathrm{H}$, Glas G, editors. Responsible medical interventions. An attempt to develop a Christian medical ethics [Verantwoord medisch handelen. Proeve van een christelijke medische ethiek]. Amsterdam: Buijten\&Schipperheijn. 1997.

10. Thomas P. General medical practitioners need to be aware of the theories on which our work depend. Ann Fam Med 2006;4:450-4.

11. Toulmin S. On the nature of the physician's understanding. J Med Philos 1976;1:32-50.

12. Tricoci P, Allen JM, Kramer JM, Califf RM, Smith SC, Jr. Scientific evidence underlying the ACC/AHA clinical practice guidelines. JAMA 2009;301:831-41.

13. Clinical Evidence. How much do we know? BMJ. 2008.

14. Bremer GJ. Changing clinical pictures: what history can teach us [Veranderende ziektebeelden; wat de geschiedenis ons kan leren]. MC 2000;55:747-8.

15. Wolffers I. Cultural sensitivities [Culturele gevoeligheid]. MC 2004;59:196-9.

16. Payer L. Medicine and Culture: Varieties of Treatment in the United States, England, West Germany, and France. New York: Penguin Books. 1988.

17. Montgomery K. How doctors think. Clnical judgement and the practice of medicine. Oxford, New York: Oxford University Press. 2006.

18. Damasio AR. Descartes' Error: Emotion, Reason, and the Human Brain. New York: Avon. 1994.

19. Damasio AR. The feeling of what happens. Body, emotion and the making of consciousness. London: Vintage, Random House. 1999.

20. Thiele LP. The Heart of Judgment. New York: Cambridge University Press. 2006.

21. PVH-werkgroep. GPs' skills profile [Competentieprofiel van de huisarts]. Utrecht. 2005.

22. Projectgroep HAO. Selection model for trainers [Selectiemodel voor opleiders]. 2005.

23. Hoofden Huisartsopleiding. Framework curriculum [Raamcurriculum 2005]. Utrecht. 2005.

24. Van der Kluit-Dijken CAL, Beek MML, Essers GTJM, Hoekstra M, Janssen D, Oosterling EMP, et al. Teachers' skills profile [Competentieprofiel van de Docent]. Utrecht. 2005.

25. Wigersma L, Van Berkestijn LGM, Giesen P. Final attainment level in GP training 2000 [Eindtermen huisartsopleiding 2000]. Basic principles. General diagnostic and therapeutic procedures [Basisprincipes. Algemeen diagnostisch en therapeutisch handelen]. 
26. Streiner DL, Norman GR. Health Measurement Scales. A practical guide to their development and use. 3 ed. Oxford: Oxford University Press. 2006.

27. Hobus PP, Schmidt HG, Boshuizen HP, Patel VL. Contextual factors in the activation of first diagnostic hypotheses: expert-novice differences. Med Educ 1987;21:471-6.

28. Hauswaldt J. Sensation of alarm - clinical decision making influenced by intuition. Kavala: EGPRN. 2006.

29. Coppens M, Gras D, Coblentz-Baumann L, Mercier A, Le Reste LY, Stolper CF. Consensus about gut feelings in France. Basel: WONCA. 2009. 

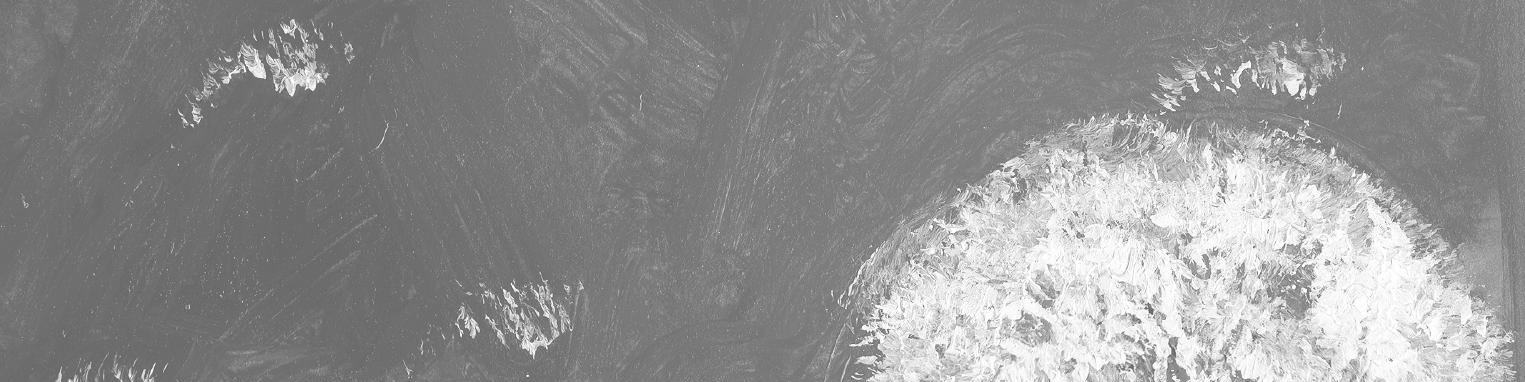

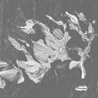
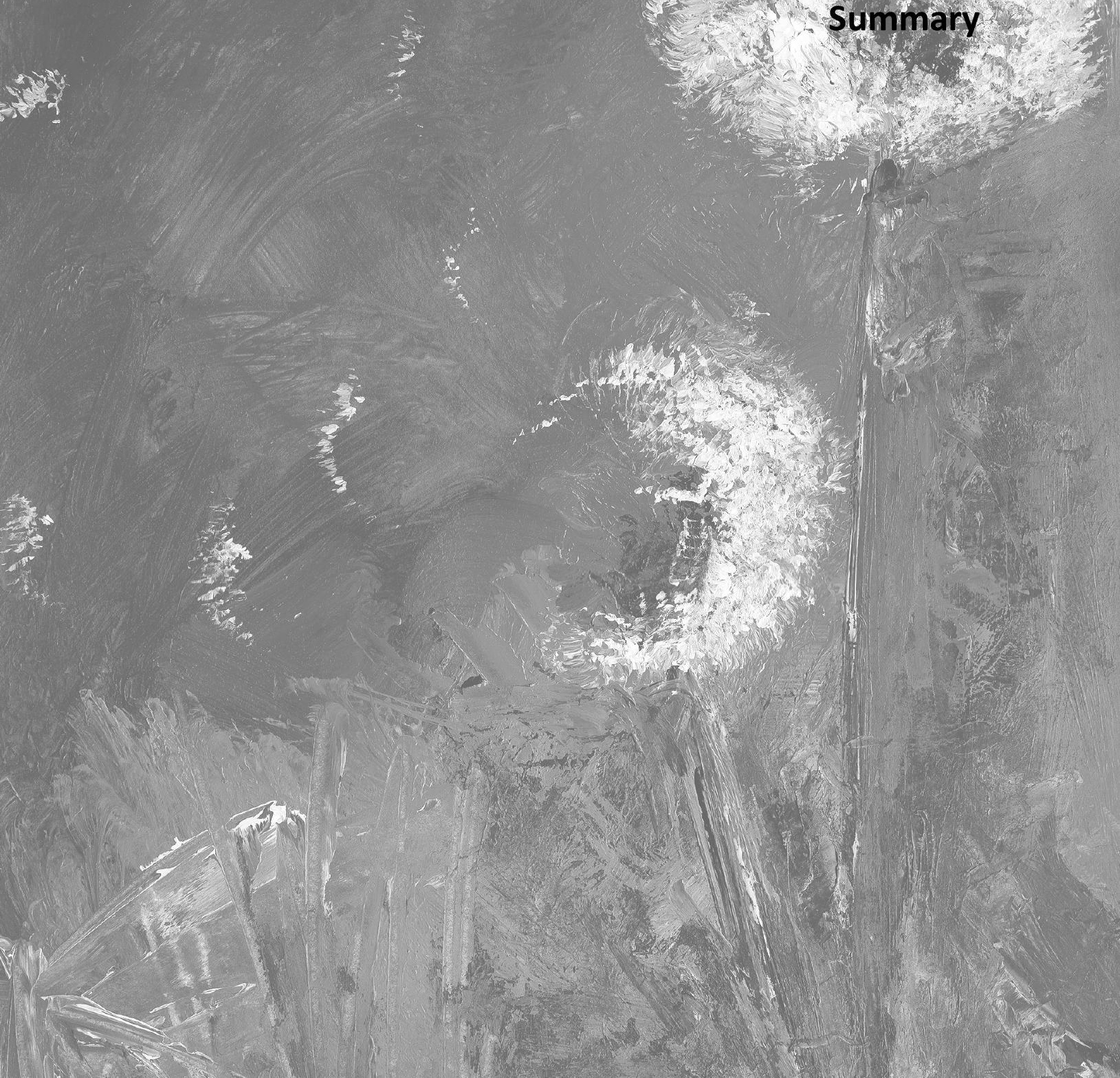


\section{Summary}

\section{A typically Dutch phenomenon or a linguistic problem?}

General practitioners (GPs) frequently experience the uneasy feeling that there may be something wrong with a particular patient, without having a clear diagnosis. In the Netherlands and in Flanders, GPs use the rather typical expression "niet-pluis" (NP) for this feeling, while the opposite, "pluis" (P), indicates a situation where a GP feels secure about the way to deal with a patient's complaint, even without having a clear diagnosis. These PNP feelings were the topic of our research. It seems to be a kind of implicit knowledge: although every Dutch-speaking GP knows what "pluis" and "nietpluis" (PNP) mean, an appropriate description was lacking, and when we started our research, the value of this phenomenon had hardly ever been studied in the Netherlands or in Flanders. At the start of our study, five years ago, we asked ourselves how to present our future findings in the international medical literature. Since PNP was found to be a well-known phenomenon in general practice all over Europe, as we show in chapter 3, we translated the Dutch expression PNP as "gut feelings". In fact, GPs in other European countries who are becoming enthusiastic about our research topic are sometimes envious of the Dutch expression PNP, as it offers such a compact and clear description of these feelings. In fact, whereas "niet pluis" is a well-described general concept in Dutch dictionaries, "pluis" is only used in medical reference books.

\section{Research questions}

Since our main goal was to gain insight into the nature and significance of gut feelings (PNP) in general practice, we formulated the following questions for the research underlying this thesis (chapter $\mathbf{1}$ ):

- What is known from the literature about the nature of diagnostic reasoning by experienced GPs?

- What meaning and significance do GPs attach to gut feelings (P or NP) and what opinions do they have about the PNP concept, as used in routine practice and during out of office hours? What determinants may play a role in developing gut feelings (PNP)?

- How can we achieve consensus about a description of gut feelings (PNP) which would enable us to operationalise this concept?

- How do disciplinary tribunals in the Netherlands use gut feelings (PNP) in their considerations and what does this mean for the professional standards on quality of health care?

- Are we able to explain how gut feelings (PNP) arise and function within the physician's knowledge network?

- What research agenda can be drawn up for the validation of the concept of gut feelings (PNP) and its value for routine practice and medical education? 


\section{Theoretical framework}

The role of gut feelings in general practice seems to be embedded in the diagnostic reasoning of GPs, which is why we started our research by studying the nature of the diagnostic reasoning of experienced GPs, by reviewing the literature on medical problem-solving and medical decision-making theories (chapter 2). If we wanted to unravel the role of gut feelings, we had to know the general theoretical frameworks by which GPs' diagnostic reasoning can be understood. The review showed that knowledge structure in an experienced GP's mind is more efficiently organized than in that of inexperienced colleagues, and that the search paths they follow to retrieve the appropriate knowledge are shorter. This means that the encyclopaedic knowledge they have gained from books during medical education is reorganized as a result of the experience they gain in practice and are made more easily accessible and applicable. Experienced doctors think along several diagnostic tracks at once, and decide how much weight to attach to the available information in the specific context of the patient, thinking in terms of proportions, in categories of certainty and in orders of magnitude instead of using exact numbers. We also learned that GPs do not always establish an exact diagnosis but predict a particular outcome. Experienced GPs are therefore characterized by their ability to correctly estimate the prior probability of a disease. As to the diagnostic role of gut feelings, GPs seem to have a prognosis in mind or at least a feeling that may alert or reassure them. Finally, a typical asset of GPs is their contextual knowledge. This means that they combine knowledge about an individual patient with knowledge about the behaviour of particular diseases in other patients and background knowledge from the scientific literature to determine the prior probability.

\section{Wider outlook}

At the beginning of our research we dreamed about a four-field table with all boxes filled with numbers. These numbers would then enable us to calculate the predictive value of gut feelings and pronounce upon the usefulness of gut feelings as a diagnostic tool in general practice and its appropriateness in medical education. However, measuring requires a measuring instrument, and since hardly anything could be found in the medical literature about gut feelings we had to build from scratch a concept with an accessible and valid description and with measurable determinants. A qualitative approach using focus groups with experienced and inexperienced GPs enabled us to evaluate the meanings and significance they attach to gut feelings and their opinions about them (chapter 4). This approach yielded information about gut feelings that are known among GPs and allowed us to develop a wider perspective on the topic. An independent moderator chaired the focus group sessions and a scenario was used to ensure that all aspects relating to our research topic would come up in the discussion, while the texts were coded by three independent researchers. Only after data saturation has been reached -after four focus group sessions including 
$28 \mathrm{GPs}$ - did we stop the information gathering process. All measures were taken to diminish the risk of bias.

The grounded theory approach was particularly suitable for analyzing the transcripts of the text, since the alternating phases of gathering and analyzing data during the consecutive focus groups led to a continuous process of exploration, reflection and comparison. After each group we adapted the scenario to clarify unclear points and to explore new questions induced by the information from the previous focus group(s). This continuous process of comparing old and new data enabled us to identify building blocks needed to ground a theoretical concept. Two types of gut feelings were distinguished, a sense of alarm and a sense of reassurance, and several determinants were found. We visualized gut feelings and interrelated determinants in a knowledge network. Most of the GPs, including inexperienced ones, trusted their gut feelings. Although the participants of the last focus group were all young, very enthusiastic doctors, who were working part-time and were familiar with evidencebased medicine they nevertheless felt positive about the guiding role of gut feelings in the diagnostic process. We were surprised by the significance GPs attached to the sense of reassurance as well as to the sense of alarm. Although not always aware of its presence, participants underlined how often a sense of reassurance steered the diagnostic process. However, some GPs distrusted gut feelings and tried to avoid them by using objective rational diagnostics, or even had difficulty developing them. They argued that there was no evidence in the literature for the value of gut feelings.

\section{Narrowing the focus}

In the next phase we approached our research topic from another point of view, commonly referred to as triangulation. This term derives from navigation where people discover their position on a map by taking bearings on two landmarks. We summarized the findings of the focus group research in six statements and asked wellknown Dutch and Belgian opinion leaders and experts in the field of general practice, working at universities in educational or research programmes to participate in a Delphi consensus procedure (chapter 5 ). The aim of this anonymous process was to determine the extent to which these experts $(\mathrm{N}=27)$ would agree with the statements presented to them. Four rounds of rating, re-formulating statements and re-rating were needed to reach sufficient consensus on seven statements (see Text box). The consensus proved to be in line with the focus group results, narrowing our scope to the well-defined concept of two kinds of gut feelings. The descriptions of the sense of alarm and the sense of reassurance have enabled us to operationalise the concept for future research, and the triangulation process increased the validity of the results. 
- Statement 1a: A 'sense of alarm' means that a GP perceives an uneasy feeling as he/she is concerned about a possible adverse outcome.

- Statement 3: A 'sense of alarm' implies that a GP worries about a patient's health status, even though he/she has found no specific indications yet; it is a sense of 'there's something wrong here'.

- Statement 2: A 'sense of alarm' activates the diagnostic process by stimulating a GP to formulate and weigh up working hypotheses that might involve a serious outcome.

- Statement 4: A 'sense of alarm' means that, if possible, the GP needs to initiate specific management to prevent serious health problems

- Statement 9: A 'sense of alarm' will decrease as the diagnosis and the right management become clearer.

- $\quad$ Statement 5: A 'sense of reassurance' means that a GP feels secure about the further management and course of a patient's problem, even though he/she may not be certain about the diagnosis: everything fits in.

- Statement 8: The 'sense of reassurance' and the 'sense of alarm' constitute a dynamic element in a GP's diagnostic process.

\section{Disciplinary tribunals and gut feelings}

Reports on interesting and instructive decisions of Dutch disciplinary tribunals published in the Dutch general medical journal Medisch Contact show that tribunals sometimes use the term gut feelings (or rather the Dutch term "niet-pluis") in their considerations when they pass judgement on physicians against whom a complaint has been filed. We were, of course, interested in the way they have dealt with the phenomenon of gut feelings since, in the Netherlands, their judgements are considered to set standards for professional attitudes and interventions. Surprisingly, the tribunals proved to be able to evaluate the role of gut feelings in the diagnostic process, even though a valid description of gut feelings and evidence for its value were still lacking (chapter 6). An exploratory study was performed by searching two Dutch digital databases over a nine-year period. The sense of alarm was mentioned in the judgments in 34 cases, mostly regarding GPs and hospital specialists. We learned from legal experts, however, that numbers are less important than the way judges have argued in these cases. The sense of alarm was usually referred to as a diagnostic tool to assess a patient's situation. Defendants were hardly ever reproached for missing the correct diagnosis, but mostly for not acting in a professional manner, indicating that a sense of alarm must be followed by further diagnostic steps in agreement with professional standards. We conclude that the sense of alarm as a diagnostic tool has been taken seriously by Dutch disciplinary tribunals. The significance of gut feelings in medicine is apparently assumed to be a kind of implicit knowledge among physicians.

Information from national representatives and key persons of the European General Practice Research Network (EGPRN) in 22 European countries showed that in most of 
these countries no central database with decisions of disciplinary tribunals is available, or such databases are not accessible for research.

\section{Third track}

Elstein \& Shwarz's selective review of the cognitive literature on the two diagnostic tracks, medical problem-solving and medical decision-making, improved our insights into the diagnostic process. We initially visualized the position of gut feelings in a diagram (chapter 4), inducing the diagnostic reasoning. Gut feelings may also bypass explicit reasoning, causing a prompt intervention, if any. However, we did not know how gut feelings arise and we could not yet explain how they influence the diagnostic reasoning. We therefore reviewed the literature on diagnostic reasoning from various perspectives, as well as on the basis of psychological theories of dual processing (chapter 7).

Dual process theories distinguish two systems: the analytical system, which is explicit, controlled, rational, effortful and relatively slow, and the non-analytical system, which is implicit, is based on tacit, automatic and effortless thought processes and is associative, intuitive and fast. It is particularly the combined and interacting analytical and non-analytical cognitive processes which explain how gut feelings may arise as a third diagnostic track, next to medical problem-solving and medical decision-making. The role of affect in non-analytical processes as a state of positive or negative feeling has been acknowledged in several dual-process theories. Affective responses as heuristics or mental shortcuts guide the diagnostic reasoning, helping physicians to navigate, mostly in an efficient way, in complex, uncertain and sometimes dangerous situations (dangerous for the patient, that is).

We conceptualized expert medical knowledge as a large and highly coherent, associative network. Since knowledge structures become richer by experience, more diversified, better coordinated and attuned to patients' problems, non-analytical reasoning will do most of the diagnostic work. Gut feelings can be explained as the result of non-analytical reasoning and are similar to intuition but more specific, as they are confined to prognostic assessments of the patient's situation, often accompanied by bodily sensations.

We then adjusted our first diagram (chapter 4) since it proved to be insufficient to visualize our later insights (chapter 7). Gut feelings act as a third track and we wish to emphasize that GPs simultaneously use elements of all tracks as result of the interaction between analytical and non-analytical processes.

\section{Research agenda}

The final step in our research path was to establish a research agenda. We wondered what research questions would enable us to validate the concept of gut feelings and estimate its usefulness for daily practice and medical education. We already knew what determinants of gut feelings play a part, but we did not yet know how their 
contribution to the development of such feelings could be measured. An appropriate method to approach this problem was the nominal group technique (NGT), since it may stimulate a controlled brain wave among experts on the topic (chapter 8). We therefore applied this technique in a study in which an independent moderator and a scenario developed in advance ensured that all four consecutive phases of the procedure were completed. Generating ideas in silence, recording and evaluating them and finally anonymously ranking the best ideas yielded a long list of research questions and corresponding appropriate designs, and the harvest became even richer when we repeated this session with different groups. In the outcome, high priority was given to questions about the prevalence and the diagnostic value, and about the validation of determinants. Most of the questions listed were actually already in our mind when we started the NGT, but we obtained more information about their priorities and, much more importantly, about the research designs that are appropriate to find valid answers. The long-list of ten main research questions and nine corresponding designs offers excellent opportunities to collaborate in international research projects.

\section{Overlooking our work}

The General Discussion (chapter 9) addresses the strengths and weaknesses of our study and offers some comments on diagnostic reasoning and medical education. It then discusses some epistemological notions and concludes with recommendations and an overview of planned activities. 

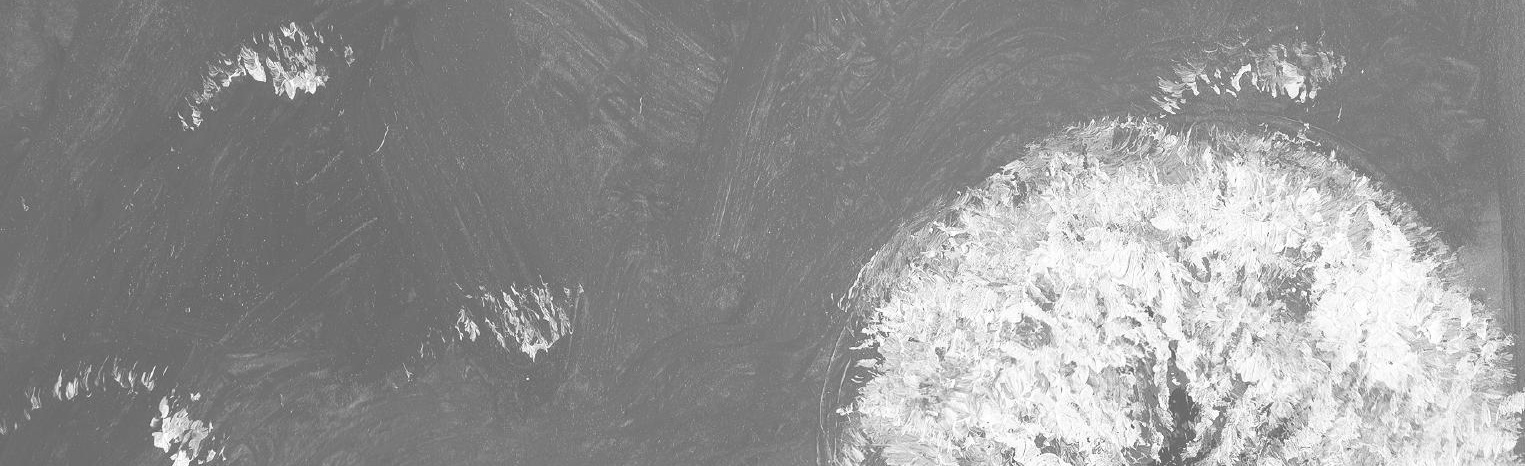

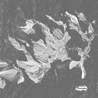
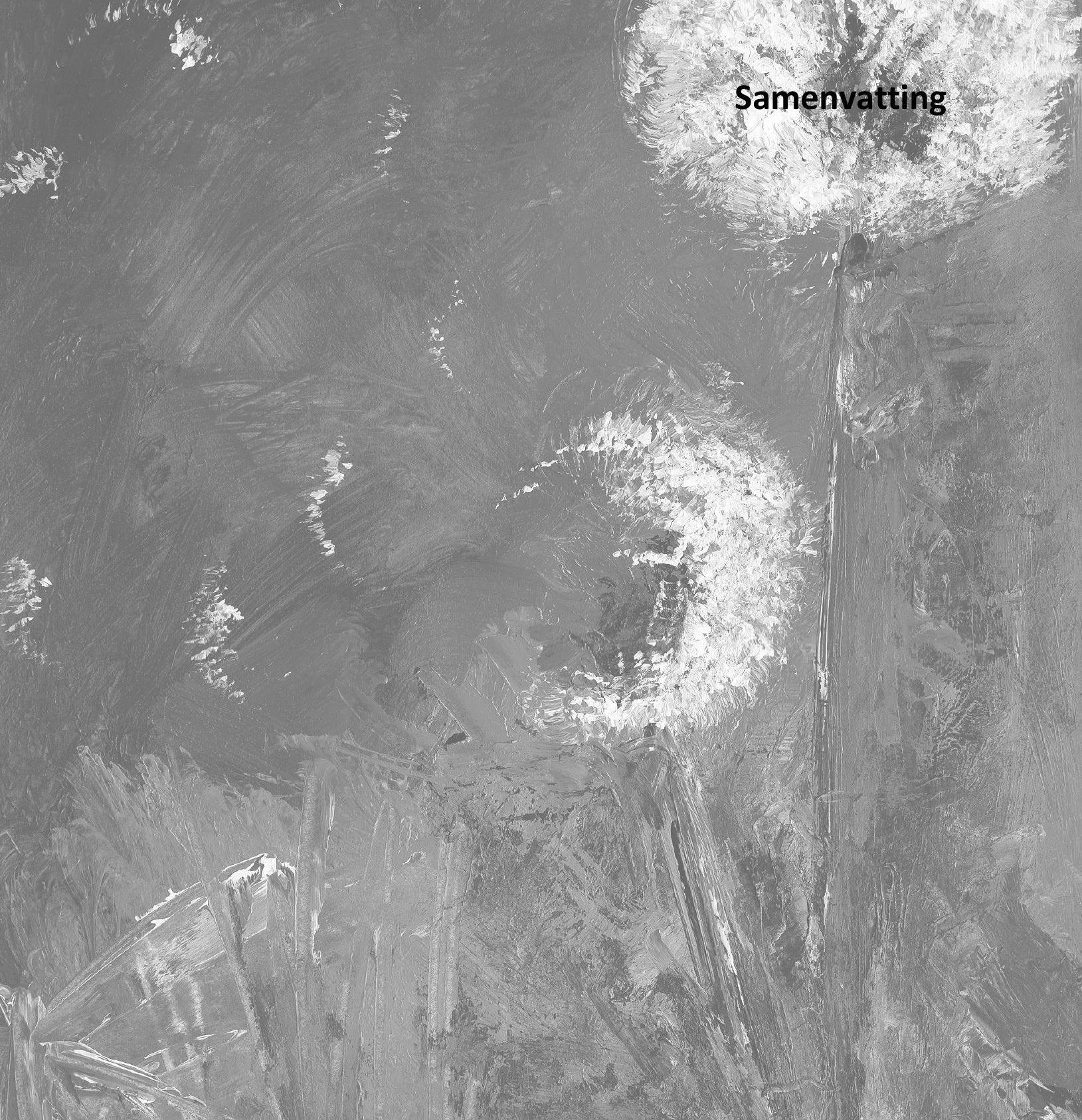


\section{Samenvatting}

\section{Hoe typisch Nederlands is het begrip 'pluis en niet-pluis'?}

Huisartsen ervaren regelmatig het wat ongemakkelijke en onrustig makende gevoel dat er iets mis is met een patiënt terwijl ze niet goed weten wat er aan de hand is. Voor dat gevoel gebruiken huisartsen in Nederland en Vlaanderen het kenmerkende gezegde dat er iets 'niet-pluis' is. In situaties waarbij de huisarts zich zeker voelt over hoe te handelen, ook al ontbreekt een duidelijke diagnose, wordt veelal de term 'pluis' gebruikt. Dit typische 'pluis en niet-pluis' gevoel (PNP) is het onderwerp van deze studie. ledere Nederlandstalige huisarts is vertrouwd met dit begrip, hoewel een goede omschrijving ontbrak toen we met het onderzoek begonnen. De diagnostische waarde van het begrip was vrijwel niet onderzocht. Het gaat hier blijkbaar om impliciet veronderstelde kennis van het begrip. Bij de start van ons onderzoek, vijf jaar geleden, vroegen we ons af hoe we de resultaten ervan zouden kunnen communiceren in de Engelstalige literatuur. Is PNP een typisch Nederlandstalig fenomeen of zou het ook buiten de grenzen door huisartsen worden herkend en benoemd? In hoofdstuk 3 doen we verslag van een survey onder Europese huisartsen waaruit blijkt dat de omschrijving van het 'niet-pluis' gevoel door alle respondenten wordt herkend. In sommige landen blijken er ook specifieke uitdrukkingen voor te zijn. Op basis van deze gegevens vertaalden we PNP in 'gut feelings'. Gaandeweg ons onderzoek ontdekten we dat huisartsen buiten Nederland en Vlaanderen soms jaloers zijn op dit Nederlandstalige begrip omdat het ingewikkelde zaken op een compacte en duidelijke manier communiceerbaar maakt. In het Groot Woordenboek van de Nederlandse Taal wordt het 'niet-pluis' begrip omschreven als 'het is daar niet in orde, niet veilig, er is iets verdachts, het spookt er'. 'Pluis' is als begrip alleen in een geneeskundig woordenboek terug te vinden. "Pluis en niet-pluis" wordt daar omschreven als het gevoel van de arts ten aanzien van een klacht of ziekte, zonder te beschikken over een diagnose. Op basis van intuïtie, ervaring en kennis kan de arts, aldus de omschrijving, veelal een onderscheid maken tussen onschuldige, nietalarmerende klachten (pluis) en ernstige aandoeningen waarvoor verdere behandeling noodzakelijk is (niet-pluis).

\section{Onderzoeksvragen}

Omdat het voornaamste doel van dit onderzoek het verhelderen van de diagnostische betekenis van PNP in de huisartsenpraktijk was, formuleerden we onderstaande vragen (hoofdstuk 1):

- Wat is in de literatuur bekend over het diagnostisch denken van ervaren huisartsen?

- Welke betekenissen geven huisartsen aan het begrip PNP voor hun dagelijks handelen, in de eigen praktijk en tijdens diensten? Welke factoren spelen naar de mening van huisartsen een rol bij de ontwikkeling van PNP? 
- Kunnen we consensus bereiken over een omschrijving van PNP die ons in staat stelt om verder onderzoek te doen naar het functioneren van dit fenomeen in de huisartspraktijk?

- Hoe wordt het begrip PNP gehanteerd door medische tuchtcolleges en wat betekent dit voor het professioneel handelen van artsen en de kwaliteit van zorg?

- Zijn we in staat een theoretisch kader te vinden waarbinnen kan worden verklaard hoe PNP ontstaat en functioneert?

- Is het mogelijk een onderzoeksagenda op te stellen gericht op het valideren van het concept PNP en op de betekenis ervan in de dagelijkse praktijk en de medische opleiding?

\section{Theoretisch raamwerk}

PNP lijkt in de huisartspraktijk ingebed te zijn in het diagnostisch denken van de huisarts en daarom hebben we ons eerst verdiept in het beloop van het diagnostisch denken van ervaren huisartsen aan de hand van literatuur over medisch probleemoplossen en medische besliskunde (hoofdstuk 2). Immers, als we de rol van PNP in de diagnostiek willen ophelderen, dienen we eerst de algemene, theoretische kaders te onderzoeken waarbinnen het diagnostisch redeneren kan worden begrepen. Dit deelonderzoek leerde ons dat ervaren huisartsen geen andere zoekstrategieën gebruiken dan onervaren collega's maar dat de kennis van ervaren huisartsen efficiënter is georganiseerd en de zoekpaden naar de juiste kennis korter zijn. De op een encyclopedische wijze gestructureerde boekenkennis die artsen tijdens hun opleiding vergaren, wordt door praktijkervaring gereorganiseerd en snel toegankelijk en toepasbaar gemaakt. Ervaren huisartsen gebruiken tegelijkertijd de verschillende denklijnen van het medisch probleemoplossen (langs psychologische lijnen) en de medische besliskunde (door wiskundige beslisregels met behulp van statistische kennis). De beschikbare informatie wordt gewogen binnen de specifieke context van een patiënt en het gewicht van die informatie wordt meestal niet in exacte getallen uitgedrukt maar eerder in kansen op een continue schaal, in categorieën van zekerheid en in orden van grootte. Ook werd duidelijk dat huisartsen niet altijd een precieze diagnose kunnen stellen maar wel een voorspelling geven van de afloop. Ervaren huisartsen zijn goed in staat de voorafkansen op een bepaalde ziekte juist in te schatten. PNP lijkt een rol te spelen in dit proces van voorspellen, van zich een idee vormen over de prognose in een bepaald geval. PNP alarmeert de huisarts of stelt hem of haar juist gerust. De contextkennis van de huisarts - alles wat hij of zij weet van de patiënt na en naast de gerichte anamnese en het lichamelijk onderzoek - blijkt een belangrijk stuk gereedschap voor de diagnostiek te zijn. Huisartsen combineren deze contextkennis met wetenschappelijke kennis en met ervaringskennis over hoe ziekten zich in het algemeen gedragen, om zo de voorafkansen op ziekte in een specifieke situatie in te schatten. 


\section{Een brede blik}

Bij de start van het onderzoekstraject droomden we van een vierveldentabel gevuld met getallen op basis waarvan we heel precies de voorspellende waarde van PNP zouden kunnen berekenen. Deze gegevens lijken immers nodig om iets te kunnen zeggen over de bruikbaarheid van PNP in de praktijk en in de opleiding geneeskunde. Om de voorspellende waarde van PNP te kunnen meten is een goed en betrouwbaar meetinstrument nodig. In de medische literatuur was echter bijna niets bekend over PNP in de huisartspraktijk en bleek een geschikt meetinstrument niet voorhanden. Dit impliceerde dat we ons eerst dienden te richten op een bruikbare en betrouwbare omschrijving van PNP inclusief de belangrijkste determinanten van het begrip. Gekozen werd voor een kwalitatief onderzoeksdesign omdat deze benadering ons het beste in staat stelde ons te richten op betekenissen die huisartsen geven aan het begrip 'niet-pluis' en hun oordeel over het begrip. We besloten om te werken met focusgroepen omdat deze methode stimuleert dat deelnemers reageren op wat anderen te berde brengen, terwijl ervaringen worden gedeeld en aangevuld (hoofdstuk 4) Op deze manier waren we in staat een zo breed mogelijke visie op het onderwerp te ontwikkelen. Een deskundige moderator zat de focusgroepsbijeenkomsten voor. We stelden vooraf een draaiboek samen dat niet bedoeld was om de bijeenkomsten inhoudelijk te sturen maar wel om ervoor te zorgen dat alle aspecten van het 'niet-pluis' fenomeen aan bod zouden komen. De teksten van de bijeenkomsten werden door drie onafhankelijke onderzoekers geanalyseerd. Na vier verschillende focusgroepen met in totaal 28 deelnemende huisartsen werden geen nieuwe gegevens meer gevonden (datasaturatie) en kon dus worden gestopt met het verzamelen van informatie.

We gebruikten de Grounded Theory benadering omdat deze manier van analyseren het mogelijk maakt de processen dataverzameling, coderen, vergelijken en reflecteren naast elkaar uit te voeren. Het categoriseren van codes kan binnen deze methode al gestart worden voordat de dataverzameling afgerond is. Door oude data te vergelijken met nieuwe kunnen nieuwe codes worden geformuleerd en nieuwe ideeën gegenereerd. De Grounded Theory benadering is erg geschikt voor het bestuderen van niet eerder onderzochte fenomenen. Op deze manier kan een theoretisch concept worden ontwikkeld, waarbij telkens oude gegevens worden vergeleken met voor dit doel specifiek verzamelde nieuwe gegevens.

Door de deelnemers werd onderscheid gemaakt tussen een 'niet-pluis' en een 'pluis' gevoel. Bij 'niet-pluis' werden drie elementen belangrijk gevonden: het gevoel dat er iets niet klopt zonder op dat moment objectieve argumenten in handen te hebben, een wantrouwen ten aanzien van de situatie met onzekerheid over de prognostische betekenis van de klachten van de patiënt en ten slotte de noodzaak in te grijpen om ernstige schade aan de gezondheid van de patiënt te voorkomen. De deelnemers omschreven het 'pluis' gevoel als een zich zeker voelen over prognose en therapie, zelfs als de huisarts niet precies weet wat de diagnose is. De meeste deelnemende huisartsen vertrouwden PNP. Dat gold ook voor de minder ervaren deelnemers. Aan 
de laatste focusgroep namen alleen vrouwelijke, in deeltijd werkende huisartsen met vijf jaar of minder ervaring deel, maar vertrouwd met evidence-based medicine. Ook zij waren positief over de rol van PNP in de huisartspraktijk. We waren verrast over het belang dat de meeste huisartsen hechtten aan PNP. De huisartsen onderstreepten hoe het 'pluis' gevoel het diagnostische denken kan sturen, ook als ze zich niet bewust waren van dat gevoel. Sommige huisartsen beschouwden PNP echter als een valkuil die zo goed mogelijk omzeild moest worden door rationele diagnostiek te verrichten. Deze huisartsen zeiden dat er geen bewijs is in de literatuur voor de diagnostische waarde van PNP.

Belangrijke determinanten van PNP waren congruente en geruststellende, discongruente en alarmerende factoren en proces verstorende factoren, evenals contextkennis, ervaring, sensaties, persoonlijkheid en opleiding. We visualiseerden onze bevindingen in een netwerk en construeerden een diagram waarbinnen de diagnostische denkstromen van de huisarts en de plaats van PNP ('gut feelings') in dit geheel worden weergegeven.

\section{Focus op consensus}

In de volgende fase benaderden we ons onderwerp vanuit een ander gezichtspunt wat ook wel triangulatie wordt genoemd. Deze term is ontleend aan de scheepvaart. Om goed te kunnen navigeren, moet de actuele positie op de kaart precies worden bepaald. Door verschillende peilingen te verrichten op de wal wordt de betrouwbaarheid van een gevonden positie verhoogd. In ons geval betekende dit dat we een andere groep collega's met specifieke ervaring naar een samenvatting van onze bevindingen uit de focusgroepbijeenkomsten lieten kijken. We legden, op zoek naar consensus, 27 experts op het gebied van huisartsgeneeskunde, verbonden aan universiteiten in Nederland en Vlaanderen, zes uitgangsstellingen voor (hoofdstuk 5). We gebruikten de Delphi consensus procedure waar in een anoniem en schriftelijk proces opvattingen van experts worden gepeild en in een score omgezet. Na elke ronde wordt het commentaar van de experts samengevat en de mate van instemming gemeten. Deze gegevens en de op basis hiervan aangepaste stellingen worden in een volgende ronde aan alle deelnemers voorgelegd met het verzoek om opnieuw te reageren en te scoren. In vier rondes bereikten we consensus over een zevental stellingen (tekstbox 1). De consensus bleek geheel in lijn te zijn met de resultaten van het focusgroepenonderzoek maar de conclusies waren nauwkeuriger geformuleerd. Het concept PNP werd hierdoor niet alleen bevestigd maar ook beter toegankelijk gemaakt voor verder onderzoek. 
Tekstbox Bereikte consensus.

Niet-pluis

- Stelling 1a: Niet-pluis betekent dat de huisarts een onbestemd gevoel heeft omdat hij/zij ongerust is over een mogelijk ongunstige afloop.

- Stelling 2: Het "niet-pluis" gevoel activeert het diagnostische proces, in de richting van het formuleren en afwegen van werkhypothesen met een mogelijk ernstige afloop.

- Stelling 3: "Niet-pluis" impliceert dat de huisarts de gezondheidssituatie van de patiënt wantrouwt hoewel hij/zij daar nog niet voldoende concreet gemaakte aanwijzingen voor heeft: hier klopt iets niet.

- Stelling 4: "Niet-pluis" betekent dat, voor zover mogelijk, een gericht beleid op het voorkomen van ernstige gezondheidsproblemen noodzakelijk is.

- Stelling 9: Een "niet-pluis" gevoel neemt af naarmate er meer duidelijkheid is over de diagnose en/of het beleid.

Pluis

- Stelling 5:"Pluis" betekent dat de huisarts zich gerust voelt over de verdere aanpak en afloop, ook al is hij/zij niet zeker van de diagnose: het klopt allemaal.

Pluis en niet-pluis

- Stelling 8: "Pluis en niet-pluis" vormen een dynamisch element in het diagnostische proces van de huisarts.

\section{Het medische tuchtrecht en PNP}

Publicaties van beslissingen van medische tuchtcolleges in Nederland in het vakblad Medisch Contact lieten zien dat tuchtcolleges soms de term 'niet-pluis' (NP) in hun overwegingen gebruikten wanneer zij tot een oordeel kwamen in zaken waar klachten tegen artsen zijn ingediend. Wij waren vanzelfsprekend geïnteresseerd in de rol van NP in die overwegingen, temeer omdat uitspraken van deze colleges in Nederland normgevend zijn voor het professioneel handelen van artsen. Bij de bestudering van deze publicaties bleken tuchtcolleges tot onze verrassing zich in staat te achten de rol van NP in het diagnostische proces te beoordelen hoewel tot dat moment een goede en betrouwbare omschrijving ervan ontbrak en er geen bewijs in de medische literatuur te vinden is voor de waarde ervan als diagnostisch instrument (hoofdstuk 6). We doorzochten twee digitale databases in Nederland en traceerden 34 uitspraken in de periode 2000-2008, waar NP als term in voorkwam. In de meeste gevallen betrof het een klacht tegen een huisarts of een specialist. Van deskundigen op het gebied van het medisch tuchtrecht begrepen we dat het aantal keren dat NP gebruikt werd minder belangrijk is dan inzicht in de manier waarop tuchtcolleges redeneerden in de betreffende casus. NP bleek beschouwd te worden als een diagnostisch instrument waarmee de situatie van de patiënt kon worden ingeschat. De veroordeelde artsen werd in bijna geen enkel geval aangerekend dat de goede diagnose gemist was maar veelal wel voor niet-professioneel handelen omdat, naar de mening van tuchtcolleges, NP gevolgd dient te worden door passend onderzoek. Medische tuchtcolleges nemen 
NP dus serieus en gaan er kennelijk van uit dat NP onder artsen een impliciet bekend en in de diagnostiek bruikbaar begrip is.

Informatie uit 22 Europese landen maakte duidelijk dat in de meeste van deze landen een centrale database met beslissingen van medische tuchtcolleges ontbreekt of vrijwel niet digitaal toegankelijk is voor onderzoek.

\section{PNP als een derde diagnostisch spoor}

In hoofdstuk 4 hebben we een diagram geconstrueerd op basis van gegevens uit de medische literatuur en ons onderzoek. In het diagram zijn de diagnostische denkstromen van de huisarts gevisualiseerd. PNP ('gut feelings') kreeg een tamelijk centrale plek omdat PNP het diagnostisch denken stimuleert. Soms echter wordt de diagnose overgeslagen omdat een directe interventie noodzakelijk lijkt. Dit schema maakte echter niet duidelijk hoe PNP ontstaat en hoe dit het diagnostisch redeneren beïnvloedt. Om die reden bestuurden we uitgebreid medische en psychologische literatuur over de manier waarop beslissingen tot stand komen (hoofdstuk 7).

'Dual process' theorieën in de psychologie onderscheiden twee denksystemen. Enerzijds is er het analytische systeem dat gekenmerkt wordt door expliciet redeneren en rationeel denken wat tijd en inspanning kost. Anderzijds is er het niet-analytische systeem dat op een impliciete, automatische wijze verloopt, snel, intuïtief en associatief en zonder veel inspanning. De combinatie van en interactie tussen beide cognitieve systemen kunnen verklaren hoe PNP zich ontwikkelt en hoe het functioneert als een derde, diagnostisch spoor naast medisch probleemoplossen en medische besliskunde. De rol van het gevoel of affect in het niet-analytische denksysteem wordt in verschillende 'dual process' theorieën onderkend en uitgelegd als een goed en veilig gevoel of als een slecht, onveilig en onrustig makend gevoel. Dit 'goede' of 'slechte' gevoel dat in bepaalde situaties op een automatische wijze wordt ervaren, fungeert als een richtingwijzer of als een kortere weg ('mental shortcut'). Het stuurt mede het diagnostisch redeneren en helpt artsen om in complexe en diagnostisch onzekere en soms gevaarlijke situaties op een veelal efficiënte wijze keuzes te maken.

Het kennisnetwerk van huisartsen wordt door praktijkervaring steeds omvangrijker, beter georganiseerd en meer afgestemd op de situatie van de patiënt. Dit netwerk vormt de 'pool' aan kennis waar het analytische en het niet-analytische denken gebruik van maken. Hoe meer ervaring een arts heeft, hoe groter de bijdrage van het niet-analytische denken aan het diagnostisch redeneren zal zijn. PNP kan worden begrepen als het resultaat van het niet-analytisch denken. Het kan worden geduid als een intuïtief spoor maar het is specifieker omdat het alleen betrekking heeft op prognostische inschattingen van de arts en vaak gepaard gaat met lichamelijke sensaties. 
Alles overziende besloten we het oorspronkelijke, diagnostische diagram (hoofdstuk 4) zo aan te passen dat onze nieuwe inzichten beter worden gevisualiseerd. PNP fungeert als een derde, diagnostisch spoor. We willen benadrukken dat huisartsen elementen van de drie diagnostische sporen, medisch probleemoplossen, medische besliskunde en PNP, tegelijkertijd kunnen gebruiken middels een interactie tussen analytische en niet-analytische processen.

\section{Onderzoeksagenda}

De laatste stap in ons onderzoeksprogramma was, gebruikmakend van de resultaten tot nu toe, het opstellen van een agenda voor toekomstig onderzoek. Welke onderzoeksvragen en bijpassende onderzoeksmethoden zijn belangrijk om het PNP concept verder te valideren en de bruikbaarheid in de dagelijkse praktijk en in de medische opleiding te onderzoeken? Hoewel inmiddels duidelijk was welke determinanten bij PNP horen, is de mate waarin deze afzonderlijke determinanten bijdragen aan PNP niet opgehelderd en de manier waarop dit gemeten kan worden evenmin. De Nominale Groep Techniek (NGT) is een geschikte methode om een onderzoeksagenda op te stellen (hoofdstuk 8). Deelnemers eraan zijn experts op een bepaald onderwerp. NGT kan worden beschouwd als een manier om een gecontroleerde brainwave van experts te veroorzaken met de bedoeling ideeën te genereren en gezamenlijk te evalueren. Een deskundige moderator zit deze bijeenkomsten voor en een vooraf opgesteld draaiboek garandeert dat alle fasen van de procedure worden doorlopen. In de eerste fase ontwikkelen de deelnemers ieder voor zich geschikte ideeën en in de volgende twee fasen worden deze ideeën geregistreerd, besproken en geëvalueerd. In de vierde en laatste fase wordt er op anonieme wijze gestemd om tot een rangschikking te komen van de vijf beste ideeën. Deelnemers waren in ons onderzoek huisartsen die verbonden waren aan universiteiten in Nederland en Vlaanderen voor het doen van onderzoek of het geven van onderwijs. Er werden drie groepen met gemiddeld zes deelnemers per groep samengesteld Op deze manier kwam een rijke oogst aan onderzoeksideeën en bijpassende designs tot stand. Tot en met de derde groep werden nieuwe ideeën gegenereerd. Onderzoek naar het voorkomen en naar de diagnostische waarde van PNP stond hoog geprioriteerd evenals de validering van determinanten. Veel van deze vragen leefden ook bij ons als onderzoekers, maar de winst van dit deelonderzoek bestond uit de prioritering van de onderzoeksvragen en, belangrijker nog, het antwoord op de kwestie welke onderzoeksmethoden het beste kunnen worden gebruikt om betrouwbare antwoorden te vinden. Een lijst van tien belangrijke onderzoeksvragen en negen bijpassende onderzoeksdesigns vormt nu de onderzoeksagenda voor de toekomst. 


\section{Een terugblik en een vooruitblik}

In het negende en laatste hoofdstuk blikken we terug op het onderzoekstraject en stellen we de sterke en zwakke kanten van het onderzoek aan de orde. Wij onderzochten als eersten de rol van PNP in het diagnostisch denken van huisartsen. We kozen in deze exploratieve fase voor kwalitatieve onderzoeksdesigns. Daardoor waren we in staat op relatief korte termijn uitgebreide en betrouwbare informatie te verzamelen. Voor het eerst in de medische literatuur is nu een vrij nauwkeurige omschrijving van PNP en haar belangrijkste determinanten gepubliceerd. Met behulp van medische literatuur over het diagnostisch redeneren en van psychologische 'dualprocess' theorieën slaagden we erin het ontstaan en het functioneren van PNP binnen het diagnostisch denken van de huisarts begrijpelijk te maken. Onze conclusie dat PNP een belangrijke rol speelt in dat diagnostisch denken wordt ondersteund door de visie die medische tuchtcolleges op PNP hebben verwoord. Tenslotte bleek de presentatie van onderzoeksresultaten op internationale congressen van huisartsen te leiden tot de formering van een internationale expertgroup die het onderzoek naar PNP ('gut feelings in general practice') gaat stimuleren en coördineren. Onze NederlandsVlaamse onderzoeksagenda kan hier een nuttige rol spelen. Een vierveldentabel met kwantitatieve gegevens over de diagnostische testeigenschappen van PNP ontbreekt nog en dat kan als een zwakke kant van onze studie worden uitgelegd. De keuze voor een primaire benadering via kwalitatief onderzoek in plaats van via kwantitatieve designs is echter heel gebruikelijk in situaties waar het onderzoeksonderwerp eerst moet worden geëxploreerd voordat meer exacte metingen kunnen worden verricht.

In hoofdstuk 9 wordt verder besproken hoe onze bevindingen passen in een in Vlaanderen ontwikkeld medisch curriculum. Vervolgens wordt kort ingegaan op de vaak geponeerde, maar ons inziens onterechte tegenstelling tussen geneeskunde en geneeskunst in het handelen van artsen en tussen ratio en affect. Er is ook empirisch, neurobiologisch bewijs dat beide aspecten onmisbaar zijn voor goede besluitvorming. Het hoofdstuk wordt afgesloten met een aantal nader uitgewerkte plannen over hoe in de medische opleiding het niet-analytisch diagnostisch redeneren kan worden getraind en hoe in de toekomst de diagnostische waarde van PNP kan worden bepaald. Tenslotte gaan we in op de mogelijkheden die internationale samenwerking in het onderzoek naar PNP biedt en al geboden heeft. Resultaten van onderzoek naar PNP in Duitsland en in Frankrijk hebben het tot nu toe ontwikkelde PNP concept bevestigd. 

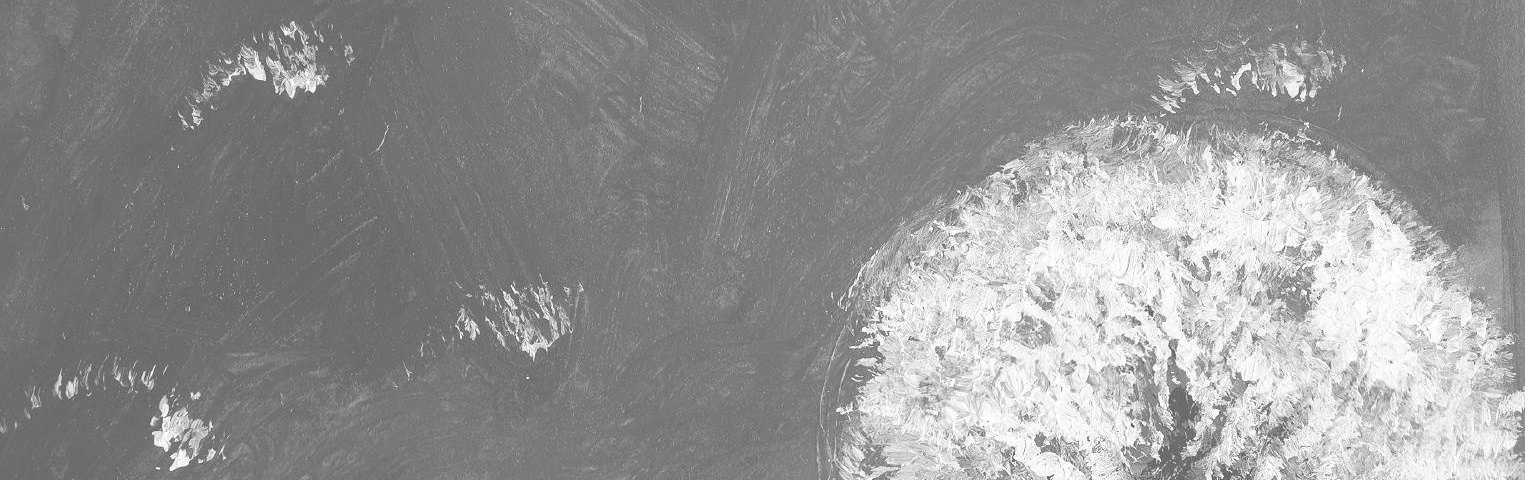

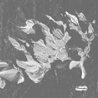
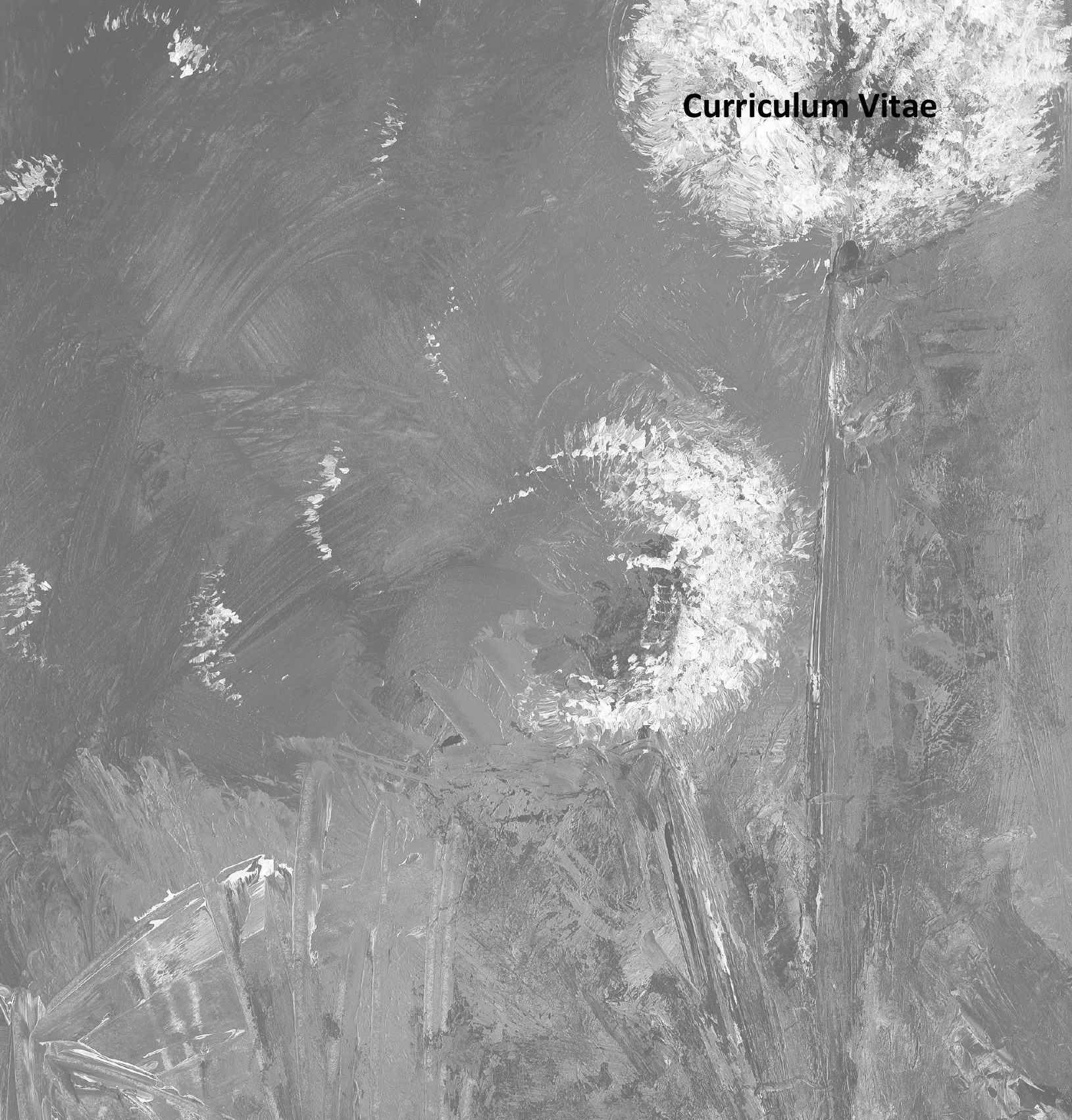


\section{Curriculum Vitae}

Erik Stolper was born in Utrecht, The Netherlands, on 9 Augustus 1950. He obtained his secondary school diploma in 1970, and graduated as a medical doctor from Groningen University in 1976, and as a general practitioner from the same university in 1978. After a period in which he was engaged in emergency relief work in refugee camps in Cambodia (1979/80), he started working as a GP in the Dutch towns of Enschede, Vaassen and Zwolle.

After a vocational traineeship in homeopathic medicine at SHO (Stichting Homeopathische Opleidingen), from which he graduated in 1990, he started working as a homeopathic physician in the village of Heerde. He also became coordinator of the Dutch Committee for (homeopathic) Methods and Validation (CMV), a position he has held since 1995. This research group published several diagnostic studies.

Erik then moved on to do a research traineeship in general practice (1999/2003), and was a member of the Committee for Scientific Research (CWO) of the Dutch College of General Practitioners (NHG) from 2004 to 2009. Since April 2004, he has also worked as a researcher at Maastricht University. He was awarded a grant by ZonMw (the Netherlands Organisation for Health Research and Development) in May 2005 for a research project on 'Gut Feelings in General Practice' [Pluis en Niet-Pluis in de Huisartspraktijk], as well as a grant from SBOH (Stichting Beroepsopleiding Huisarts) in January 2009.

In addition to his professional activities, he has been engaged in managerial activities for the church, and in ecclesiastical development work. He is happily married to Dineke van den Engel and they have 6 children and 6 grandchildren.

e-mail address: cf.stolper@hag.unimaas.nl

website: www.gutfeelingsingeneralpractice.eu 
